Humberto de Mello Brandão

Efeito da insulina sobre a superovulação de ovelhas e desenvolvimento de um sistema nanoestruturado para permeação de mucosa 
Humberto de Mello Brandão

\section{Efeito da insulina sobre a superovulação de ovelhas e desenvolvimento de um sistema nanoestruturado para permeação de mucosa}

Tese apresentada ao Programa de PósGraduação em Reprodução animal da Faculdade de Medicina Veterinária e Zootecnia da Universidade de São Paulo para a obtenção do título de Doutor em Ciências.

Departamento:

Reprodução Animal

Área de concentração:

Reprodução Animal

Orientador:

Prof. Dr. Ed Hoffmann Madureira

São Paulo

2009 
Autorizo a reprodução parcial ou total desta obra, para fins acadêmicos, desde que citada a fonte.

\section{DADOS INTERNACIONAIS DE CATALOGAÇÃO-NA-PUBLICAÇÃO}

(Biblioteca Virginie Buff D'Ápice da Faculdade de Medicina Veterinária e Zootecnia da Universidade de São Paulo)

T.2216

Brandão, Humberto de Mello

Efeito da insulina sobre a superovulação de ovelhas e desenvolvimento de um sistema nanoestruturado para permeação de mucosa / Humberto de Mello Brandão. -- 2009.

124 f. : il.

Tese (Doutorado) - Universidade de São Paulo. Faculdade de Medicina Veterinária e Zootecnia. Departamento de Reprodução Animal, São Paulo, 2009.

Programa de Pós-Graduação: Reprodução Animal.

Área de concentração: Reprodução Animal.

Orientador: Prof. Dr. Ed Hoffmann Madureira.

1. Ovelha. 2. Insulina. 3. Superovulação. 4. Nanopartícula. 5. Diabetes. I. Título. 
UNIVERSIDADE DE SÃO PAULO

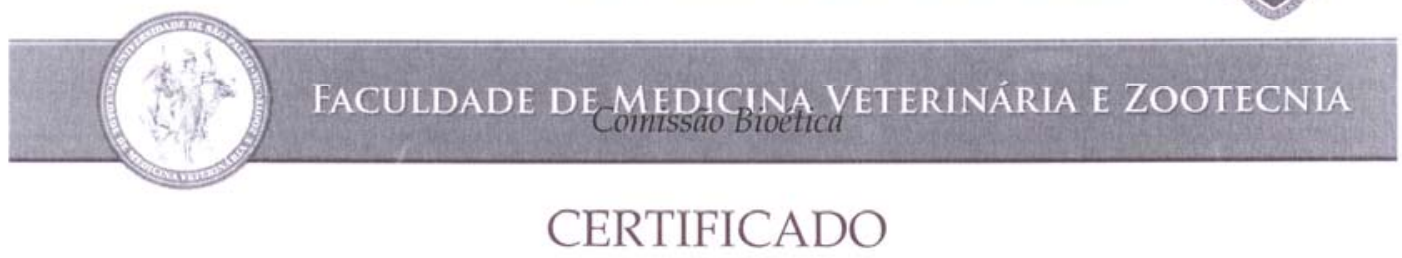

Certificamos que o Projeto intitulado "Avaliação da influência da insulina em ovelhas superovuladas e desenvolvimento de uma formulação nanoestruturada de longa ação contendo insulina", protocolado sob o n¹580/2009, utilizando 32 (trinta e dois) ovelhas, sob a responsabilidade do Prof. Dr. Ed Hoffmann Madureira, está de acordo com os princípios éticos de experimentação animal da Comissão de Bioética da Faculdade de Medicina Veterinária e Zootecnia da Universidade de São Paulo e foi aprovado em reunião de 20/05/09.

We certify that the Research "Evaluation of the effects of the insulin in superovulated ewe and development of long action nanostructured formulation with insulin load", utilizing 32 (thirty two) ovine, protocol number 1580/2009, under the Prof. Dr. Ed Hoffmann Madureira, agree with Ethical Principles in Animal Research adopted by Bioethic Commission of the School of Veterinary Medicine and Animal Science of University of São Paulo and was approved in the meeting of day $05 / 20 / 09$.

São Paulo, 21 de maio de 2009

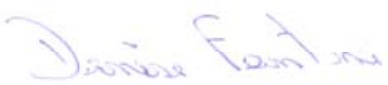

Profa Dra Denise Tabacchi Fantoni

Presidente da Comissão de Bioética FMVZ/USP 


\section{FOLHA DE AVALIAÇÃO}

Nome: BRANDÃO, Humberto de Mello

Título: Efeito da insulina sobre a superovulação de ovelhas e desenvolvimento de um sistema nanoestruturado para permeação de mucosa

Tese apresentada ao Programa de PósGraduação em Reprodução animal da Faculdade de Medicina Veterinária e Zootecnia da Universidade de São Paulo para a obtenção do título de Doutor em Ciências.

Data:

\section{Banca Examinadora}

Prof. Dr. Instituição

Assinatura Julgamento

Prof. Dr. Instituição

Assinatura Julgamento

Prof. Dr. Instituição

Assinatura Julgamento

Prof. Dr . Instituição

Assinatura Julgamento

Prof. Dr. Instituição Julgamento 


\section{AGRADECIMENTOS}

Aos meus dois orientadores Prof. Ed Hoffmann Madureira e Profa. Annelise de Souza Traldi pela paciência, amizade e ensino.

À Harumi Doi Shiraishi, secretária do departamento de reprodução animal VRA, pela presença, disposta sempre a ajudar.

Às mãos amigas de Priscila do LDH pelo auxílio na dosagem da progesterona e José Nélio na estatística.

Aos estagiários da Unincor e da Embrapa Gado de Leite pela paciência e dedicação.

Ao corpo docente da Universidade de São Paulo pela possibilidade do conhecer e partilhar.

À minha esposa Tarita, ouvinte, companheira de todas as horas estando eu presente ou ausente.

Aos meus pais e irmãos por fazerem parte da torcida pelas minhas vitórias.

À todos que rezaram por mim, sogra, tios, tias, amigos e voltaram o olhar de Deus mais um pouquinho para esta minha conquista.

Especialmente à Deus por estar vivo e conseguir vencer mais esta etapa amparado por seu olhar de pai zeloso. 


\section{RESUMO}

BRANDÃO, H. M. Efeito da insulina sobre a superovulação de ovelhas e desenvolvimento de um sistema nanoestruturado para permeação de mucosa.[Insulin Effect on Sheep Superovulation and the Development of a nanostructure systemfor mucosal permeability]. 2009. 124f. Tese (Doutorado em Ciência). Faculdade de Medicina Veterinária e Zootecnia, Universidade de São Paulo, 2009.

A nutrição é o principal fator que interfere com o desempenho reprodutivo de mamíferos e vários metabólitos e hormônios, envolvidos no metabolismo energético, funcionam como sinalizadores para o eixo hipotálamo-hipófise-gonadal. $\mathrm{O}$ fato de a insulina ser o principal regulador da homeostase de glicose e exercer controle em diversas etapas do metabolismo de gorduras e proteínas, fez desse hormônio, ao longo do processo evolutivo, um modulador da reprodução. Neste estudo, no experimento 1, foi comparado o efeito da hiper e da hipoinsulinemia, no desempenho reprodutivo relacionado ao processo de superovulação em ovelhas. Para tanto foram utilizadas 27 ovelhas, distribuídas em 3 grupos: a) controle; b) grupo diabético (induzido pela aplicação I.V. de $50 \mathrm{mg} / \mathrm{kg}$ de Alloxano); e c) grupo hiperinsulinêmico (suplementado com $1 \mathrm{Ul} / \mathrm{kg}$ ao dia, S.C.). Todos os animais receberam um pessário vaginal, contendo $60 \mathrm{mg}$ de medroxiprogesterona no D0 e foram superovulados, com 250UI de FSH em 6 aplicações, iniciadas no D10. No D12 aplicaram-se 250UI de eCG e $125 \mu \mathrm{g}$ de cloprostenol sódico. As ovelhas foram submetidas à monta natural e a colheita dos embriões foi realizada no sétimo dia após o início do estro. Em média, os teores de insulina medidos a partir da remoção dos pessários até a colheita dos embriões foram de $14,52 \pm 0,4$ vs $10,18 \pm 0,5$ vs $20,05 \pm 0,9 \mu \mathrm{Ul} / \mathrm{mL}$ $(P<0,01)$, respectivamente para os grupos controle, diabético e hiperinsulinêmico. Os valores para glicemia, medida no mesmo período, para os grupos controle, diabético e hiperinsulinêmico foram de $83,1 \pm 2,1 \mathrm{mg} / \mathrm{dL}$ vs $241,2 \pm 9,2 \mathrm{mg} / \mathrm{dL}$ vs $53,9 \pm 2,7 \mathrm{mg} / \mathrm{dL}$ $(\mathrm{P}<0,01)$, respectivamente. O grupo diabético apresentou menor produção de corpos lúteos que os animais controle e hiperinsulinêmicos ( $5 \pm 1,1$ vs $10.3 \pm 1,9$ e $11,3 \pm 1$, $\mathrm{P}<0,01$ ); pior qualidade do $\mathrm{CL}$ ( $\mathrm{IQCL}$ de $2,3 \pm 0,3$ vs $1.6 \pm 0,1$ e $1.3 \pm 0,1, \mathrm{P}<0,01$ ), menor número de embriões $(2.3 \pm 1.2$ vs $7.9 \pm 1.97$ e $7.4 \pm 1.2, P<0,01)$, que por sua vez também foram de pior qualidade (IQE de $2.9 \pm 0.2$ vs $2 \pm 0.1$ e $1.7 \pm 0.1, P<0,01$ ). De um modo geral, os animais hiperinsulinêmicos apresentaram desempenho 
reprodutivo semelhante aos do grupo controle; entretanto, embora o número de embriões colhidos não tenha sido estatísticamente diferente, os dados são sugestivos de que o estado de hiperinsulinemia pode favorecer o crescimento embrionário, acelerando seu desenvolvimento. Histologicamente, os $\mathrm{CL}$ do grupo diabético se apresentaram com hipotrofia das LLC, aumento no número de células apoptóticas por campo, quando comparados aos dos tratamentos controle e hiperinsulinêmico. Adicionalmente, no experimento 2, foram testadas formulações de nanopartículas de quitosana, para liberação sustentada de insulina, bem como permeação da mucosa gastrintestinal. A formulação de insulina nanoestruturada, sem proteção lipídica,administrada pela via SC, liberou $92,1 \pm 3,01 \%$ da quantidade inicial de insulina, in vitro, porém o padrão desejado de liberação sustentada não foi atingido. No teste in vivo, a redução da glicemia foi apenas parcial (em média $60,8 \pm 3,2 \%$ em relação à linha de base). O sistema composto por nanopartículas incorporadas à matriz lipídica, no teste in vitro, liberou apenas $15,6 \pm 4,9 \%$ da quantidade inicial. Entretanto, quando administrada pela via oral, no teste in vivo, reduziu, embora parcialmente, a glicemia de ovinos diabéticos alloxano induzidos (em média $79,88 \pm 4,3 \%$ em relação à linha de base). Concluiu-se, com base no experimento 1 que, na dose empregada, a insulina não foi capaz de produzir benefícios reprodutivos que justifiquem seu uso em protocolos de superovulação de ovelhas. As concentrações subfisiológicas de insulina, observadas nos animais diabéticos podem ser responsáveis por uma série de alterações metabólicas, que, em conjunto, comprometeram os índices de desempenho reprodutivo, relacionados ao processo de superovulação e induziram um quadro inicial de regressão de CL. Com isso, observou-se que o uso de ovelhas, como modelo animal, para estudo dos efeitos reprodutivos da insulina, foi satisfatório. Pela análise do experimento 2, concluiu-se que o sistema de nanopartículas revestidas por lipídios foi capaz de carrear a insulina, ao longo do trato digestivo de um ruminante, no teste in vivo, e compatibilizar sua permeação através da mucosa intestinal, mantendo a atividade biológica do hormônio, o que consiste em um fato inédito.

Palavras-chave: Ovelha; insulina; Superovulação; Nanopartícula; Diabetes 


\section{ABSTRACT}

BRANDÃO, H. M. Insulin Effect on Sheep Superovulation and the Development of a nanostructure systemfor mucosal permeability. [Efeito da insulina sobre a superovulação de ovelhas e desenvolvimento de um sistema nanoestruturado para permeação de mucosa] 2009. 124f. Tese (Doutorado em Ciência). Faculdade de Medicina Veterinária e Zootecnia, Universidade de São Paulo, 2009.

Nutrition is the main factor that interferes with the reproductive development of all mammals and many of the matobolites and hormones involved in the energetic metabolism work as signaling factors for the hypothalamic-pituitary-gonadal axis. The fact of insulin being the main regulator of glucose homeostasis and having control in various steps of fat and protein metabolism, has made this hormone, along the evolution process, a reproductive modulator. In the first experiment of this study, the effect of hyper and hypoinsulinemia were compared as to how it affects the reproductive performance related to superovulation in sheep. For this, 27 sheep were used, distributed in 3 groups a) control, b) diabetic group (induced by IV injection of $50 \mathrm{mg} / \mathrm{kg}$ of Alloxan); and c) hyperinsulinemic group (supplemented with $1 \mathrm{Ul} / \mathrm{kg}$ per day, SC). All animals received a vaginal pessary, containing $60 \mathrm{mg}$ of medroxiprogesterone on D0 and were superovulated, with 250Ul of FSH in 6 applications, starting on D10. On D12 250Ul of eCG and $125 \mu \mathrm{g}$ of sodium cloprostenol were administered. The sheep were submitted to natural breeding and embryo collection was performed on the seventh day after the beginning of estrus. In average, the insulin levels recorded starting on the day of pessary removal until the day of embryo collection were $14,52 \pm 0,4$ vs $10,18 \pm 0,5$ vs $20,05 \pm 0,9 \mu \mathrm{UI} / \mathrm{mL}$ $(P<0,01)$, respectively for the control, diabetic and hyperinsulinemic groups. The values for glycemia, measured during the same period, for the control, diabetic and hyperinsulinemic groups were $83,1 \pm 2,1 \mathrm{mg} / \mathrm{dL}$ vs $241,2 \pm 9,2 \mathrm{mg} / \mathrm{dL}$ vs $53,9 \pm 2,7$ $\mathrm{mg} / \mathrm{dL} \quad(P<0,01)$, respectively. The diabetic group showed less corpus lutea production than the control and hyperinsulinemic groups ( $\pm \pm 1,1$ vs $10.3 \pm 1,9$ and $11,3 \pm 1, P<0,01$ ); worse $C L$ quality (IQCL de $2,3 \pm 0,3$ vs $1.6 \pm 0,1$ and $1.3 \pm 0,1$, $P<0,01)$, less number of embryos $(2.3 \pm 1.2$ vs $7.9 \pm 1.97$ and $7.4 \pm 1.2, P<0,01)$, which by its turn were also of worse quality (IQE de $2.9 \pm 0.2$ vs $2 \pm 0.1$ and $1.7 \pm 0.1, P<0,01$ ). Overall, hyperinsulinemic animals presented a reproductive performance similar to the control group; however, although the number of embryos recovered were not 
statiscally different, the data suggest that the state of hyperinsulinemy can favor embryo growth, acceleratting its development. Histologically, the CLs from the diabetic group showed hypotrophy of LLC and an increase in the number of apoptotic cells per field when compared to the control and hyperinsulinemic treatments. In addiction, the second experiment, chitosan nanoparticles formulations were tested, for sustained release of insulin as well as gastrointestinal mucosal permeability. The nanostructured insulin formulation without lipid protection, administered SC, released $92,1 \pm 3,01 \%$ of the initial insulin amount, in vitro, however, the desired standard for sustained release was not reached. In the in vivo test, the reduction in glycemia was only partial (on average $60,8 \pm 3,2 \%$ in relation to base line ). In the in vitro test, the system made up of nanoparticles incorporated to the lipid matrix, released only $15,6 \pm 4,9 \%$ of the initial amount. However, when administered orally, in the in vivo test, it reduced, although only partially, the glycemia of the alloxan induced diabetic ovines (on average $79,88 \pm 4,3 \%$ in relation to base line). In conclusion, based on the first experiment, the applied insulin dose was not able to produce any reproductive benefits that may justify its use in sheep superovulation protocols. The sub-physiologic insulin concentrations observed in the diabetic animals may be responsable for various metabolic alterations, that together compromised the reproductive performance levels related to the superovulation process and induced an initial state of $C L$ regression. With that, it was noticed that the use of sheep as an animal model for the study of the effects of insulin on reproduction was satisfatory. By analyzing the second experiment, it was concluded that the nanoparticles system coated with lipids was able to carry insulin along the ruminant digestive during the in vivo test, show permeability through the intestinal mucosa, maintaining the hormone biologic activity, which is a new and unpublished fact.

Key words : Ewe; insulin; Superovulation; Nanoparticles; Diabetes 


\section{LISTA DE FIGURAS}

Figura 1: Comparação teórica de uma formulação de insulina convencional e uma nanoestruturada com liberação sustentada. Eixo $Y$ refere-se a valores hipotéticos de concentração plasmática de insulina. Página 39

Figura 2: Cadeia polimérica de quitosana, monômero da esquerda desacetilado e monômero da direita acetilada. Adaptado (PAYET e TERENTJEV, 2008). Página 42

Figura 3: Esquema de pontos de amostragem para histologia de corpo lúteo ovino, adaptado de Neves e Marques (2002). Página 58

Figura 4: Sistema para preparo de nanopartículas por geleificação ionotrópica. Página 60

Figura 5: Sistema para avaliação do padrão de liberação in vitro de nanopartículas. Página 63

Figura 6: Concentração plasmática de insulina em ovelhas diabéticas, hiperinsulinêmicas e controle superovuladas. Página 67

Figura 7: Concentração plasmática de glicose em ovelhas diabéticas, hiperinsulinêmicas e controle superovuladas $(P<0,01)$. Página 67

Figura 8: Fígado de ovelha diabética: (A) superfície externa; (B) superfície de corte. Setas branca representam evidenciação da lobulação. Página 71

Figura 9: (A) Micrografia da região centrolobular hepática de ovelha (pertencente ao grupo diabético) com esteatose moderada (200x); (B) Hepatócito com de animal (pertencente ao grupo diabético) com esteatose moderada (1000x). (C) Região centrolobular hepática sem alterações histológicas, representativas dos tratamentos controle e hiperinsulinêmico (200x). Setas branca representam vacuolização intracelular. Página 71

Figura 10: (A) Ovário ovino apresentando CL grau 1; (B) Ovário ovino apresentando CL grau 2; (C) Ovário ovino apresentando CL grau 3; (D) Corte histológico de CL do grupo diabético com folículo luteinizado (seta preta), folículo com parede parcialmente luteinizada (seta vermelha) e folículo terciário (seta branca) (25x); (E) Transição direta entre células luteínicas e celulas da teca no folículo não ovulado (1000x); (F) Detalhe do folículo com parede parcialmente e grande número de células em apoptose (200x). Página 72

Figura 11: (A) Corte histológico de CL de ovelha compatível com os grupos controle e hiperinsulinêmico: região rica em tecido conjuntivo (seta azul), LLC típica (seta cinza) e SLC típica (seta branca), 200x; (B) Corte histológico de CL de ovelha diabética: célula apoptótica (seta vermelha) e retração celular (seta branca), 200x; @ Célula LLC em apoptose, com núcleo picnótico (seta branca), retração célula (seta preta) e área de vacuolização celular (seta vermelha). Página 74

Figura 12: Concentração plasmática de progesterona de ovelhas diabéticas, hiperinsulinêmicas e controle superovuladas. Página 75

Figura 13: Distribuição de tamanho de nanopartículas brancas (linha contínua) e de nanopartículas contendo insulina (linha tracejada). Página 76

Figura 14: Eletromicrografia de Varredura (A) Nanopartículas de quitosa/TPP contendo insulina e (B) nanopartículas de quitosana/TPP (70.000x). Página 77

Figura 15: Cromatograma da insulina amostrada durante o ensaio de liberação in vitro. Página 77

Figura 16: Espectro infravermelho da insulina, nanopartícula branca, tripolifosfato de sódio (TPP), nanopartícula contendo insulina e quitosana. Página 78 


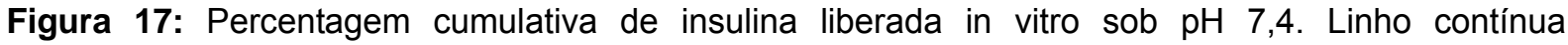
nanopartículas contendo insulina, linha tracejada nanopartículas contendo insulina incorporada em matriz lipídica. Página 79

Figura 18: Média da concentração plasmática de insulina e de \% de glicose em função da linha de base, após a administração subcutânea de $8 \mathrm{~mL}$ soro fisiológico. Página 80

Figura 19: Média da concentração plasmática de insulina e de \% de glicose em função da linha de base, após a administração subcutânea de nanopartículas branca. Página 80

Figura 20: Média da concentração plasmática de insulina e de \% de glicose em função da linha de base, após a administração subcutânea de 2,5Ul/kg de insulina. Página 81

Figura 21: Média da concentração plasmática de insulina e de \% de glicose em função da linha de base, após a administração subcutânea de 2,5Ul/kg de insulina nanoestruturada. Página 81

Figura 22: Média da concentração plasmática de insulina e de \% de glicose em função da linha de base, após a administração via ora de $50 \mathrm{Ul} / \mathrm{kg}$ de insulina. Página 82

Figura 23: Média da concentração plasmática de insulina e de \% de glicose em função da linha de base, após a administração via ora de $50 \mathrm{Ul} / \mathrm{kg}$ de insulina nanoestruturada. Página 82

Figura 24: Média da concentração plasmática de insulina e de \% de glicose em função da linha de base, após a administração via ora de $50 \mathrm{Ul} / \mathrm{kg}$ de insulina nanoestruturada incorporada em matriz lipídica. Página 82 


\section{LISTA DE TABELAS}

Tabela 1: Composição percentual (\%) dos ingredientes do sal proteinado Página 51

Tabela 2: Critérios usados na classificação morfológica dos Corpos Lúteos Página 56

Tabela 3: Média do ácido graxo não esterificado plasmático em $\mathrm{mmol} / \mathrm{L}$ e seu respectivo erro padrão em ovelhas controle, diabéticas e hiperinsulinêmicas superovuladas Página 68

Tabela 4: Intervalo médio de tempo entre a remoção do pessário vaginal e o início do estro (horas) e a duração média do estro de ovelhas, controle, diabéticas e hiperinsulinêmicas e seu respectivo erro padrão Página 68

Tabela 5: Média e seus respectivos erros padrões de número de $C L$, do IQCL, IQE e do total de estruturas colhidas, embriões, mórulas, blastocistos e estruturas degeneradas ou não fecundadas coletados de ovelhas controle, diabéticas e hiperinsulinêmicas superovuladas Página 69

Tabela 6: Média da área e do diâmetro maior das LLC e SLC, número de células apoptóticas por campo e percentagem de células endotelial e pericito, tecido luteínico e tecido conjuntivo e fibroblasto, com seus respectivos erros padrões em corpos lúteos de ovelhas controle, diabéticas e hiperinsulinêmicas Página 73

Tabela 7: Média de progesterona plasmática em $\mathrm{ng} / \mathrm{mL}$ e seus respectivos erros padrões em ovelhas controle, diabéticas e hiperinsulinêmicas superovuladas e seu respectivo erro padrão Página 75 


\section{LISTA DE ABREVIATURAS}

\begin{tabular}{|c|c|}
\hline$\mu \mathrm{mol}$ & micromol \\
\hline$\%$ & percentagem \\
\hline AGV & ácido graxo volátil \\
\hline ATP & adenosina trifosfato \\
\hline BSA & albumina sérica bovina \\
\hline CL & corpo lúteo \\
\hline CoA & coenzima A \\
\hline CYP 17 & citocromo P450 17-a-hidroxilase \\
\hline EMR & endocitose mediada por receptoras \\
\hline $\mathrm{FSH}$ & hormônio folículo estimulante \\
\hline GD & grupo diabético \\
\hline CG & grupo controle \\
\hline $\mathrm{GH}$ & grupo hiperinsulinêmico \\
\hline GLUT & proteína transportadora de glicose \\
\hline GnRH & hormônio liberador de gonadotrofina \\
\hline GTP & guanidina trifosfato \\
\hline IGF & fator de crescimento semelhante à insulina \\
\hline I.M. & intramuscular \\
\hline IPD & índice de polidisperção \\
\hline Ir & receptores de insulina \\
\hline IRS & substrato para receptores de insulina \\
\hline I.V. & Intravenoso \\
\hline $\mathrm{kDa}$ & kilodalton \\
\hline $\mathrm{kg}$ & kilogramas \\
\hline $\mathrm{KL}$ & kit ligant \\
\hline $\mathrm{kV}$ & kilovolts \\
\hline LH & hormônio luteinizante \\
\hline LLC & células luteínicas maiores \\
\hline MAP & proteína ativadora de mitose \\
\hline MEV-FEG & microscopia eletrônica de varredura de alta resolução \\
\hline $\mathrm{mg}$ & miligramas \\
\hline $\mathrm{mmol}$ & milimol \\
\hline $\mathrm{mV}$ & milivolts \\
\hline $\mathrm{nm}$ & nanômetros \\
\hline NEFA & ácido graxo não esterificado \\
\hline $\mathrm{PgF} 2 \alpha$ & prostaglandina $\mathrm{F} 2 \alpha$ \\
\hline $\mathrm{pH}$ & potencial de hidrogênio \\
\hline PRIF & folículo primário \\
\hline PROF & folículo primordial \\
\hline RAS & proteína do sarcoma de rato \\
\hline RNAm & ácido ribonucleico mensageiro \\
\hline S.C. & subcutâneo \\
\hline SLC & células luteínicas menores \\
\hline StAR & proteína da regulação aguda da esteroidogênese \\
\hline TPP & tripolifosfato \\
\hline UI & unidade internacional \\
\hline VLDL & lipoproteína de muito baixa densidade \\
\hline V.O. & via oral \\
\hline
\end{tabular}




\section{SUMÁRIO}

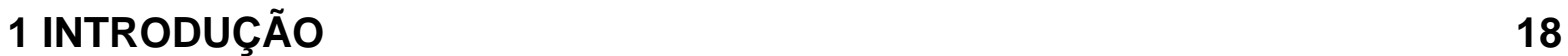

2 REVISÃO DE LITERATURA $\quad 20$

$\begin{array}{ll}2.1 .1 & 20\end{array}$

2.1.2 MECANISMOS PELOS QUAIS A INSULINA PODE

INFLUENCIAR A REPRODUÇÃO

2.1.3 EFEITOS INESPECÍFICOS DA INSULINA 21

2.1.4 INTERAÇÃO NUTRIÇÃO, INSULINA E REPRODUÇÃO 24

2.1.5 INSULINA/EIXO HIPOTÁLAMO-HIPOFISÁRIO 27

2.1.6 INSULINA E ESTEROIDOGÊNESE 28

2.1.7 INSULINA E DESENVOLVIMENTO FOLICULAR 29

2.1.8 INTERAÇÃO INSULINA E OUTROS EFETORES BIOLÓGICOS 31

2.1.9 INSULINA E CRESCIMENTO EMBRIONÁRIO 33

2.1.10 ESTRATÉGIAS DE USO DA INSULINA VISANDO AUMENTAR A PRODUÇÃO EMBRIONÁRIA E OS ÍNDICES REPRODUTIVOS 34

2.1.11 INDUÇÃO DO STATUS DE HIPOINSULINEMIA EM OVINOS 35

2. 2 DESENVOLVIMENTO DE UMA FORMULAÇÃO

NANOESTRUTURADA DE INSULINA $\quad 37$

$\begin{array}{ll}\text { 2.2.1 INTRODUÇÃO } & 37\end{array}$

2.2.2 SISTEMAS NANOESTRUTURADOS EM LIBERAÇÃO SUSTENTADA DE FÁRMACOS

$\begin{array}{ll}2.2 .3 \text { QUITOSANA } & 40\end{array}$

2.2.4 QUITOSANA EM SISTEMAS DE LIBERAÇÃO SUSTENTADO 43

2.2.5 PREPARO DE NANOPARTÍCULAS DE QUITOSANA 45

2.2.6 NANOPARTÍCULAS CONTENDO INSULINA 47

3. OBJETIVO GERAL 49

3. 1 OBJETIVOS ESPECÍFICOS 49

4. HIPÓTESE

5. MATERIAL E MÉTODOS 51

5.1 EXPERIMENTO 1

5.1.1 ANIMAIS E LOCAL DO EXPERIMENTO 51 
5.1.2 PROCEDIMENTO EXPERIMENTAL 52

5.1.3 TRATAMENTO CONTROLE

5.1.4 INDUÇÃO DA HIPERINSULINEMIA 53

5.1. 5 INDUÇÃO DO DIABETES

5.1.6 COLHEITA DE SANGUE $\quad 54$

5.1.7 COLHEITA E AVALIAÇÃO EMBRIONÁRIA 55

5.1.8 AVALIAÇÕES DE HORMÔNIOS, GLICOSE E NEFA 56

5.1.9 COLHEITA DE AMOSTRAS PARA AVALIAÇÃO

HISTOPATOLÓGICA

5.1.10 ANÁLISE ESTATÍSTICA

5.1.11 MODELO ESTATÍSTICO $\quad 59$

$\begin{array}{ll}5.2 \text { EXPERIMENTO } 2 & 59\end{array}$

5.2.1 NANOENCAPSULAMENTO DA INSULINA E

CARACTERIZAÇÃO DO SISTEMA

5.2.1.1 CONFECÇÃO DAS NANOPARTÍCULAS 59

5.2.1.2 ANÁLISE DE ESPALHAMENTO DE LUZ DINÂMICO 61

5.2.1.3 ANÁLISES DE MICROSCOPIA ELETRÔNICA DE

VARREDURA DE ALTA RESOLUÇÃO (MEV) 61

5.2.1.4 ESPECTROSCOPIA DE INFRA VERMELHO 62

5.2.2 DETERMINAÇÃO DO PADRÃO DE LIBERAÇÃO 62

5.2.2.1 DETERMINAÇÃO DO PADRÃO DE LIBERAÇÃO IN VITRO 62

5.2.2.2 FORMULAÇÕES PARA AVALIAÇÃO DA LIBERAÇÃO IN VIVO 63

5.2.2.3 ANIMAIS E LOCAL DO ENSAIO DE LIBERAÇÃO IN VIVO 64

6. RESULTADOS 66

6.1 EXPERIMENTO 1

6.1.1 OBSERVAÇÕES GERAIS

6.1.2 CONCENTRAÇÃO PLASMÁTICA DE INSULINA E GLICOSE 66

6.1.3 ÁCIDO GRAXO NÃO ESTERIFICADO (NEFA) 68

6.1.4 DURAÇÃO DO ESTRO

6.1.5 RESPOSTA OVARIANA $\quad 69$

6.1.6 AVALIAÇÃO HISTOPATOLÓGICA $\quad 70$

6.1.7 CONCENTRAÇÃO PLASMÁTICA DE PROGESTERONA

$\begin{array}{ll}\text { 6.2 EXPERIMENTO } 2 & 75\end{array}$ 
$\begin{array}{ll}\text { 6.2.2 ENSAIOS DE LIBERAÇÃO } & 78\end{array}$

7. DISCUSSÃO

$\begin{array}{ll}\text { 7.1 EXPERIMENTO } 1 & 83\end{array}$

7.1. 1 CONDIÇÃO METABÓLICA

7.1.2 DURAÇÃO DO ESTRO

$\begin{array}{ll}\text { 7.1.3 RESPOSTA OVARIANA } & 86\end{array}$

7.1.4 AVALIAÇÃO HISTOPATOLÓGICA 92

7.1.5 PRODUÇÃO DE PROGESTERONA 94

$\begin{array}{ll}7.2 \text { EXPERIMENTO } 2 & 96\end{array}$

7.2.1 CARACTERIZAÇÃO FISICOQUÍMICA 96

$\begin{array}{ll}\text { 7.2.2 ENSAIOS DE LIBERAÇÃO } & 98\end{array}$

9. CONCLUSÕES 105

10. REFERÊNCIAS BIBLIOGRÁFICAS 106 


\section{INTRODUÇÃO}

Frequentemente os níveis plasmáticos de insulina e ou a capacidade de resposta celular a este hormônio vêm sendo associados a diversas alterações fisiológicas ou patológicas que podem culminar com o aumento ou déficit nos índices reprodutivos dos mais diferentes mamíferos.

Em humanos, a importância reprodutiva desse hormônio, tem sido profundamente estudada, fruto do crescente impacto social externado no aumento contínuo da população obesa, na ampliação dos casos de anorexia e bulimia nervosas e na necessidade de ajustes finos na reprodução assistida de mulheres com mais de trinta e cinco anos de idade (ESHRE Capri Workshop Group, 2006).

Tanto em roedores quanto em humanos, o balanço energético negativo induz a uma baixa concentração plasmática basal de insulina, associada à desnutrição, anorexia e bulimia nervosas e diabetes tipo 1 não tratada, que apresentam como principais sintomas reprodutivos amenorréia, oligomenorréia, falhas ovulatórias e elevadas taxas de abortamento e partos prematuros (LAUGHLIN et al., 1998; ESHRE Capri Workshop Group, 2006). Em contrapartida, dietas desbalanceadas e supernutrição podem induzir ao aparecimento de elevados índices de resistência a insulina, correlacionados à distúrbios reprodutivos (STEIN et al., 1995; ESHRE Capri Workshop Group 2006; VAN HOOFF et al., 2006).

Nos animais de produção, como bovinos, ovinos, caprinos e suínos, os estudos que averiguam os impactos reprodutivos da insulina são escassos, contudo sua concentração plasmática também já foi associada a alterações reprodutivas, sejam elas positivas, como aumento da ciclicidade, aumento do recrutamento folicular, incremento no número de crias por parto e maior desenvolvimento embrionário (MANN et al., 2003; FRANCO et al., 2004), ou sejam negativas, como falha ovulatória e de ciclicidade, baixa qualidade embrionária e abortamento (ADAMIAK et al., 2005; WEBB et al., 2006).

Do ponto de vista econômico, segundo observações de Franco et al. (2004), a baixa taxa de desfrute do rebanho de ruminantes brasileiro é decorrente, em grande parte, de índices reprodutivos insuficientes que, por sua vez, podem ser mitigados pela adoção de estratégias capazes de incrementar a taxa de ciclicidade, 
ovulação e implantação embrionária.

Algumas pesquisas apontam que a suplementação estratégica com insulina pode incrementar os índices reprodutivos em ruminantes ou mesmo sobrepor falhas de manejo nos programas de reprodução assistida e natural, melhorando assim a fertilidade. Entretanto, o uso estratégico deste hormônio vem sendo negligenciado, e por isso necessita ser mais estudado (SELVARAJU et al., 2003; SARATH et al., 2008; SUGUNA et al., 2009).

Experimentos fazendo uso simultâneo de animais diabéticos e hiperinsulinêmicos, permitem avaliar o efeito da insulina em condições extremas, i.e., deficiência e excesso do hormônio e com isso o favorecimento na detecção de seus efeitos.

Nesse contexto, o uso de ovelhas superovuladas como modelo animal pode gerar conhecimentos capazes de compreender melhor os efeitos reprodutivos desse hormônio nessa espécie, e gerar subsídios para o uso racional e estratégico da insulina objetivando alcançar elevado desempenho reprodutivo. 


\section{REVISÃO DE LITERATURA}

Serão abordados cinco tópicos com o intuito de oferecer informações importantes para a compreensão dos potenciais efeitos reprodutivos da insulina, das formas de indução do diabetes em ovelhas e do uso de formulações que contém nanopartículas para a produção animal.

\subsubsection{INSULINA}

A insulina é a principal responsável pelo aporte direto ou indireto de energia às células dos mais diversos órgãos e tecidos nos mamíferos. Sua grande importância biológica foi externada pela comunidade científica através da concessão de dois prêmios Nobel ao químico Frederick Sanger. Um em 1958, por ter elucidado a estrutura molecular desse hormônio e outro em 1980 pelo sequenciamento dos pares de base do gene que codificam a sua molécula (ROSENFELD, 2002).

In vivo, a insulina é produzida exclusivamente pelas células $B$ das llhotas de Langherans, no pâncreas (GAYTON, 2002). Esse hormônio tem como precursor biológico a pró-insulina, que é clivada em três fragmentos: peptídeo $C$ e cadeias $A$ e $B$, que possuem, respectivamente, 31, 21 e 30 aminoácidos. A união das cadeias polipeptídicas A e B por duas pontes de dissulfeto resulta na insulina em sua forma ativa que apresenta ainda uma terceira ponte dissulfeto intracadeia $A$ ligando duas cisteínas nas posições 6 e 11 (LADISCH e KOHLMANN, 1992).

Existem pequenas diferenças estruturais na insulina de diferentes espécies. A bovina difere da humana por apresentar uma alanina substituindo uma treonina nas posições A8 e B31 e uma valina substituindo uma isoleucina na posição A10, enquanto que os ovinos diferem de bovinos apenas pela substituição de uma serina por uma glicina na posição A9 (TRENKLE, 1972). Essas diferenças acabam por conferir variações na massa molecular e ponto isoelétrico da insulina entre as espécies, e oscilam entre 5733,5 a 5808 Daltons e pH de 5,3 e 5,4. Apesar dessas diferenças, existe bioatividade cruzada entre as insulinas de diferentes espécies, mesmo que em intensidade variada (LADISCH e KOHLMANN, 1992; FERNANDES et al., 2007). 
A insulina é pouco solúvel no meio aquoso quando os valores de $\mathrm{pH}$ estão próximo do neutro. Em condições mais alcalinas ou em ácido acético diluído com pH oscilando entre dois e três, consegue-se soluções com concentrações próximas de 2 $\mathrm{mg} / \mathrm{mL}$. Em tampões fisiológicos, quando atinge concentrações superiores a 0,6 $\mu \mathrm{g} / \mathrm{mL}$, os monômeros de insulina se organizam de forma reversível, por ligações de hidrogênio não covalentes, em dímeros e principalmente hexâmeros, formando assim pequenos cristais. Tais cristais conferem ao hormônio grande estabilidade de estocagem sob refrigeração que, uma vez administrados, se dissociam na forma monomérica e biologicamente ativa (SIGMA-ALDRICH, 2006; FERNANDES et al., 2007).

De forma geral, o padrão de secreção da insulina nos animais é modulado principalmente pelos níveis plasmáticos de glicose e em menor escala por aminoácidos, ácidos graxos, incretinas, colicistocinina, secretina, polipeptídio inibidor gástrico, glucagon e através de inervações que liberam acetilcolina (STABENFELDT,1995). No caso de ruminantes,a concentração plasmática desse hormônio é menor que as dos monogástricos (TAKASU et al., 2007), e tem sua secreção fortemente estimulada pela concentração plasmática de ácidos graxos voláteis (AGV). Dos principais AGVs, o butirato exerce maior efeito estimulador em sua secreção (TRENKLE, 1972; COSTA et al., 2008),bem como administração endovenosa de aminoácidos como o a arginina e a leucina (TRENKLE, 1972).

\subsubsection{MECANISMOS PELOS QUAIS A INSULINA PODE INFLUENCIAR A REPRODUÇÃO}

As características pleiotrópicas da insulina atuando de diferentes maneiras sobre o crescimento celular, metabolismo de carboidratos, anabolismo proteico e lipídico, e a multifatorialidade (i.e. endócrinos, parácrinos e autócrinos) dos parâmetros que regem a reprodução em mamíferos torna difícil a compreensão isolada dos mecanismos pelos quais esse hormônio pode influir na reprodução. Para facilitar a compreensão, alguns desses efeitos serão agrupados em subitens, o que não significa que eles ocorram isoladamente.

\subsubsection{EFEITOS INESPECÍFICOS DA INSULINA}


A síntese de proteínas nos mais diversos tecidos depende sobretudo da concentração intracelular de aminoácidos e de substrato para geração de energia (CHOWDHURY e ORKOV, 1997). Por distintas maneiras, a insulina é capaz de estimular o aumento intracelular de proteína e de glicose e seus precursores.

Prior e Smith demostraram em 1983 que a administração exógena de insulina a bovinos promove a captação plasmática de aminoácidos, a incorporação celular de proteína e a redução da taxa de oxidação de aminoácidos de cadeia ramificada.

O nível de proteína intracelular é determinado pelo seu turnover, isto é, a diferença entre a sua taxa de síntese e a de degradação. Uma vez degrada, a proteína tem seus aminoácidos liberados no citoplasma e podem ser incorporados às outras proteínas em processo de confecção, ganhar a circulação sanguínea ou simplesmente serem oxidados (LORENZONI et al., 2007).

Quando avaliado o turnover de proteínas citoplasmáticas, a insulina exerce tanto um efeito estimulatório sobre o anabolismo proteico ( BONADONNA et al., 1993), quanto inibitório sobre o catabolismo proteico (HYDE et al., 2003). No caso dos ovinos, ocorrem os dois fenômenos, embora, a inibição do catabolismo proteico pareça ser mais intensa que o estímulo ao anabolismo (WESTER et al., 2000). Uma provável explicação para essa diferença é a ação supressiva da insulina sobre a atividade da $\alpha$-cetoácido de cadeia ramificada desidrogenase, enzima que cataliza o primeiro passo irreversível da descarboxilação oxidativa dos aminoácidos de cadeia ramificada (LOBLEY, 1992).

Outra forma de favorecimento do anabolismo proteico pela insulina é o aumento da captação de aminoácidos originários do plasma sanguíneo. De acordo com Hyde e colaboradores (2003), existem aproximadamente 23 subgrupos de sistemas transportadores transmembrana de aminoácidos conhecidos. Destes, o sistema $A$, talvez o mais estudado, tem sua atividade aumentada em resposta à adição de insulina (BONADONNA et al., 1993; HATANAKA et al., 2006). Como consequência, ocorre aumento da eficiência e da velocidade de captação de aminoácidos, disponibilizando-os para o crescimento e divisão celular (FEHLMANN et al.,1979).

A principal fonte de energia para os ruminantes advém dos ácidos graxos voláteis produzidos durante a fermentação ruminal que, juntamente com os aminoácidos gliconeogênicos, são os principais responsáveis pela manutenção do 
nível basal de glicose sanguínea (CHOWDHURY e ORKOV, 1997).

O transporte transmembrana de glicose é realizado por um grupo de proteínas carreadoras, as GLUT, que apresentam diferentes isoformas com capacidade distinta de resposta à administração de insulina (SANTOS et al., 2004 a e b). Dessas, as isoformas 1 e 4 foram mais profundamente estudadas. A GLUT 1 atua independente dos níveis plasmáticos de insulina e é responsável pelo transporte basal de glicose, enquanto que a ação da GLUT 4 é altamente dependente do estímulo hormonal e se encontra no citoplasma de células insulinasensível (KASANICKI e PILCH, 1990). Os transportadores GLUT 4 já foram encontrados em células endometriais (MUONI et al., 2004), da granulosa, da teca e luteínicas (NISHIMOTO et al., 2006) e em embriões na fase de mórula e blastocisto (HEYNER et al., 1989; SANTOS et al., 2000).

O receptor de insulina (Ir), uma vez estimulado, ativa por intermédio de sua subunidade $\beta$ a fosforilação da tirosina em alguns substratos citoplasmáticos, isto é, substrato de receptor de insulina-1 (IRS-1) e das proteínas relacionadas ao sistema SHC (src homology/a-collagen related protein), que acabam por ativar os mensageiros secundários fosfolipase $C_{\gamma}$ e fosfatidilinusitol 3-quinase, dando início ao processo de translocação da vesículas citoplasmáticas contendo GLUT 4 para a membrana fosfolipídica externa, e aumentando, assim, a captação de glicose. A fosforilação da IRS-1 e das proteínas relacionadas ao sistema SHC resultam também em efeitos mitogênico, antilipolítico e estimulatório da glicogênese, o primeiro mediado pelo complexo Ras/GTP sobre a MAP quinase (mitogem activated protein kinase), enquanto os dois últimos são mediados pela proteína quinase $B$ (SASAKI, 2003).

De forma geral, a insulina, além de promover o ingresso celular de glicose, acaba por aumentar as fontes intracelulares de energia, modulando a atividade e/ou transcrição de enzimas-chave de rotas metabólicas envolvidas no metabolismo energético, como a glicogênio sintase , 6 - fosfofruto quinase, piruvato quinase, piruvato desidrogenase, ATP citrato liase, acetil-Co A carboxilase e ácido graxo sintase, e a redução da atividade da glicose - 6 - fosfatase, frutose - 1,6 - difosfato aldolase, piruvato carboxilase, fosfoenolpiruvato carboxilase e lipase sensível a hormônio (DE HEDGE et al., 1988; BURNOL et al., 1988; SASAKI, 2003). 


\subsubsection{INTERAÇÃO NUTRIÇÃO, INSULINA E REPRODUÇÃO}

O status nutricional é um importante determinador da capacidade reprodutiva de mamíferos, assim tanto metabólitos quanto hormônios envolvidos no metabolismo energético são excelentes sinalizadores para o eixo reprodutivo (LEE et al., 2008). $O$ fato de a insulina ser o maior regulador da homeostasia de glicose e exercer controle em diversas etapas do metabolismo de gorduras e proteínas, fez desse hormônio, ao longo do processo evolutivo, um dos moduladores do crescimento, da reprodução e, em alguns casos, do tempo de vida (PLUM et al., 2006).

Tanto em monogástricos (PLUM, 2006) quanto em ruminantes (TRENKLE, 1972), a baixa ingestão de matéria seca, bem como seu perfil composicional e energético, conduzem o animal a um nível insulinêmico baixo e a um balanço energético negativo.

Em muitas espécies, períodos prolongados de balanço energético negativo e o grau de sua intensidade são associados a falhas ou à paralisação de processos reprodutivos (ESHRE Capri Workshop Group 2006; WEBB et al., 2006 ). Em humanos, cerca de um terço das mulheres que apresentam perdas de 10 a $15 \%$ do peso corpóreo tendem a manifestar um quadro clínico de oligomenorréia ou amenorréia (ESHRE Capri Workshop Group 2006). Nos animais de produção, esse fenômeno se repete, externando-se em anestro, falhas de ovulação, cistos foliculares, perdas embrionárias e morte fetal (FRANCO et al., 2004; VANHOLDER et al., 2006; COSTELLO et al., 2008). Além de aparecerem nos períodos carenciais impostos pela restrição alimentar, algumas dessas manifestações clínicas são bastante frequentes em bovinos no pósparto imediato (CHAGAS et al., 2007) e em pequenos ruminantes no terço final da gestação, vinculado a quadros clínicos de toxemia cetogênica (SCHILLO, 1992). O anestro e a falha de ovulação no pósparto de ovinos e caprinos é muito pouco estudado, visto que os partos normalmente ocorrem na contra estação, conferindo um maior período parto/concepção e possibilitando a recuperação da condição física e o retorno à ciclicidade (SCHILLO, 1992).

Quando o balanço energético negativo se instala no animal, ocorre uma queda nas concentrações de insulina (HAYIRLI, 2006). Essa queda é considerada 
por muitos autores como o mecanismo de disparo da lipólise, acarretando em liberação de ácidos graxos não esterificados (NEFA) na circulação sanguínea como fonte de energia alternativa à glicose e aos compostos gliconeogênicos (CHILLARD et al., 2000; ADEWUYI et al., 2005).

Para a produção de energia, o NEFA adentra nas mitocôndrias ou peroxissomos e ganham o clico da $\beta$-oxidação, nos quais são oxidados e produzem acetil-CoA, $\mathrm{NADH}+\mathrm{H}^{+}$e $\mathrm{FADH}_{2}$ (ADEWUYI et al., 2005). O ingresso do acetil-CoA no ciclo do ácido cítrico é dependente do oxaloacetato que, em condições adequadas devem seguir a razão de 1:1 para a produção de um citrato (VAN KNEGSEL et al., 2005). No fígado, quando as concentrações de acetil-CoA são maiores que as de oxaloacetato, o excedente é convertido em corpos cetônicos e o próprio NEFA é reesterificado em triacilglicerol (ADEWUYI et al., 2005).

O transporte sanguíneo dos triglicerídeos produzidos no fígado é realizado na forma de lipoproteína de muito baixa densidade (VLDL) (KATOH, 2002). Entretanto, os ruminantes possuem baixa capacidade de secretar os triglicerídeos na forma de VLDL e estes acabam por se acumular no fígado, ocasionando esteatose hepática (ADEWUYI et al., 2005). Esse acúmulo é acompanhado da redução de colesterol livre, esteres de colesterol, fosfolípedes, citrato e glicogênio no fígado, comprometendo sua função que, dentro outras, é produzir IGF-I (BOBE et al., 2004).

Em elevadas concentrações, o NEFA também exerce um efeito citotóxico nos tecidos periféricos (EMERY, et al., 1992) pelo fato de alterar a fluidez da membrana celular e reduzir a capacidade de síntese proteica (HAYIRLI, 2006). O impacto dessa toxicidade na parte reprodutiva pode ser constatado por testes in vitro que já identificaram redução da taxa de maturação de oócitos e na competência de desenvolvimento embrionário, quando expostos ao NEFA (LEROY et al., 2008) e ao aumento no índice de apoptóse nas células da granulosa de bovinos (VANHOLDER et al., 2005). O aumento do NEFA também induz a uma queda na resposta à insulina, basicamente pela redução da expressão gênica da GLUT4, provável downregulation dos receptores de insulina e decrécimo na fosforilação dos IRS-1 (BELL e BAUMAN, 1997; BOBE 2004; HAYIRLI, 2006).

A elevação da concentração de NEFA pode comprometer também a esteroidogênese por um decréscimo na liberação hipotalâmica de LHRH, uma baixa pulsatilidade do LH e queda da responsividade ovariana ao LH (SCHILLO, 1992). Ademais, o aumento circulatório do NEFA e o aparecimento de um quadro de 
esteatose hepática induzem à queda na concentração plasmática dos esteres de colesterol, que é precursor dos hormônios esteróides (OIKAWA e KATOH, 1997) e consequente diminuição de sua captação no corpo lúteo (KATOH, 2002). O mecanismo pelo qual esse processo ocorre é o somatório de vários eventos, passando pela redução dos receptores de estrógeno hepático; redução da produção da apolipoproteína B-100, proteína responsável pela associação dos triglicerídeos ao VLDL; redução da apolipoproteína A-I, um polipeptideo excencial para o transporte de colesterol via lipoproteína de alta densidade; e redução da lecitina:colesterol aciltransferase, enzima chave para produção dos esteres de colesterol (KATOH, 2002). De uma forma geral, da-se uma queda da produção de estrógeno pelo folículo dominante e de progesterona no corpo lúteo (OIKAWA e KATOH, 1997; KATOH, 2002; BUTLER, 2003).

Efeito oposto é observado quando o balanço energético é positivo. Animais que se encontravam em anestro retomam a ciclicidade, a taxa de concepção aumenta e os índices reprodutivos como um todo tendem a melhorar (FRANCO et al., 2004). Gong (2002) demonstrou que o aumento da densidade energética da dieta pode aumentar a concentração plasmática média de insulina em bovinos, e este incremento resultou em início mais precoce da atividade cíclica pós-parto. Mais recentemente, Garnsworthy e colaboradores (2008) comparando dietas isoenergéticas em bovinos leiteiros, observaram que as dietas ricas em carboidratos induziam a níveis plasmáticos de insulina mais elevados. Ainda nesse experimento, identificou-se uma correlação positiva entre insulina e o número de folículos com diâmetro máximo de $5 \mathrm{~mm}$ na onda folicular que precedia à ovulação. Em ovinos, caprinos e suínos o efeito do flushing, um aumento temporário do aporte energético na dieta durante os dezenove dias que precedem os acasalamentos, aumenta o número de ovulações e há como resultado o aumento da taxa de natalidade (WEBB et al., 2006).

Por outro lado, existem relatos de que a superalimentação associada à obesidade pode induzir a um quadro clínico de resistência à insulina concomitantemente à hiperinsulinemia (VERMON et al. 1990). Nesta situação, efeitos reprodutivos negativos com manifestações clínicas de hiperandrogenismo, ovários policísticos, amenorréia e oligomenorréia, anovulações, macrossomias e baixos índices na fertilização in vitro e na injeção espermática intracitoplasmática foram observados em humanos e cobaias (STEIN et al., 1995; ESHRE Capri 
Workshop Group, 2006; VAN HOOFF et al., 2006). Em bovinos, detectou-se queda na qualidade oocitária e no crescimento embrionário inicial (Adamiak et al., 2005) e em ovinos Lozano e colaboradores (2002) identificaram aumento da mortalidade embrionária.

\subsubsection{INSULINA/EIXO HIPOTÁLAMO-HIPOFISÁRIO}

O GnRH (hormônio liberador de gonadotrofina) é o controlador inicial do eixo hipotálamo-hipofisário-gonadal, produzido por uma pequena população de neurônios hipotalâmicos que, uma vez estimulados, o lança no sistema porta hipofisário. $\mathrm{Na}$ adenohipófise, estimula tanto a secreção quanto a produção de FSH e LH (hormônio folículo estimulante e hormônio luteinizante).

A concentração periférica de insulina em ovinos é diretamente proporcional ao nível de ingestão de energia alimentar (BASSETT et al., 1971) e como ela passa facilmente a barreira hematoencefálica, funciona como um dos importantes sinalizadores para o eixo hipotálamo-hipófise (SCHILLO, 1992).

Estudos em ratos demonstraram que o gene que codifica a expressão do $\mathrm{GnRH}$ possui uma sequência promotora de aproximadamente 1250 pares de base a qual, quando estimulada por fatores transcricionais produzidos pela ação da insulina sobre os Ir, ocasionou um aumento na ordem de quatro vezes em sua transcrição (BRUNING, 2000; LEE et al., 2008), o que justifica os relatos de aumento da pulsatilidade do GnRH estimulado pela insulina (MARTIN et al, 2004; BLANCHE et al, 2006), o qual pode resultar em maior pulsatilidade tanto de FSH quanto de LH (ADASHI, 1981). Blanche e colaboradores (2006) relataram que em carneiros diabéticos a injeção de pequenas doses de insulina no terceiro ventrículo culminou com um aumento na frequência de pulsos de LH, normalizando a pulsatilidade do hormônio quando comparada ao controle. Em humanos (LAUGHLIN et al., 1998), baixos níveis de insulina foram correlacionados positivamente com queda na pulsatilidade de LH, e culminou em desenvolvimento de amenorréia funcional hipotalâmica e falhas de ovulação, com o restabelecimento dos níveis plasmáticos de insulina a pulsatilidade do LH se normalizou. Manifestações clínicas semelhantes também foram relatadas em bovinos por Butler (2003).

Por outro lado, Clarke e colaboradores (1990) relataram que níveis suprafisiológicos de insulina podem suprimir completamente por horas a liberação 
pulsátil de LH. Esse efeito foi atribuído a um estresse da função neuroendócrina, causado pela redução dos precursores de energia prontamente disponíveis no sistema circulatório.

\subsubsection{INSULINA E ESTEROIDOGÊNESE}

Evans et al. (1981) relataram que à medida que os folículos e os corpos lúteos vão crescendo, ocorre um aumento na capacidade esteroidogênica de ambos, que culmina em aumento da produção de estrógeno e progesterona respectivamente; portanto, a adequada produção desses hormônios ao longo do ciclo estral é um forte indício do desenvolvimento saudável dessas estruturas.

Ao investigar as células da granulosa, da teca interna e luteais de suinos, Quesnel (1999) observou grande quantidade de receptores de insulina. Segundo o autor, a marcante presença desses receptores nas células é decorrente da elevada importância que tal hormônio tem para a esteroidogênese adequada dessas duas glândulas.

Um potente efeito sinérgico entre LH e insulina foi observado na transcrição do gene responsável pela produção de receptores de LDL (LDLr) e do gene da proteína da regulação aguda da esteroidogênese (StAR) em células suínas da granulosa previamente luteinizadas (SEKAR e VELDUIS, 2004). Nesse caso, a ação conjunta desses dois genes promovem um incremento na esteroidogênese, uma vez que o aporte intracelular de colesterol pode ser mantido pela maior concentração de LDLr, bem como pelo aumento da eficiência de seu transporte transmembrana mitocondrial proporcionado pela StAR.

Stein et al. (1995) demonstram que a insulina aumentou a capacidade de clivagem da cadeia lateral do colesterol em células luteínicas de rato, resultando em maior produção de andrógenos e progesterona in vivo e de progestinas in vitro. Nesse experimento os achados foram atribuídos ao aumento da concentração protéica no citocromo $\mathrm{P} 450 \mathrm{scc}$, que é o sistema enzimático crucial na conversão do colesterol em progesterona. Spicer em 2005, utilizando cultivo de células da teca de bovinos, também constatou um aumento na produção de progesterona decorrente da adição de insulina ao meio de cultura. Lemley e colaboradores (2008) observaram que a insulina exerce um efeito conservador da concentração plasmática de progesterona, fato explicado pela redução da expressão gênica das 
enzimas pertencentes ao citocromo P450 2C e 3A em hepatócitos, que são sistemas enzimáticos responsáveis pelo catabolismo hepático da progesterona.

A citocromo P450 17-a-hidroxilase (CYP17) é um conjunto enzimático responsável por duas reações sequenciais na biossíntese da testosterona e do estrógeno. Munir et al. (2004) descreveram um aumento na atividade da CYP17, de forma dose dependente, quando a insulina foi adicionada ao meio de cultivo de células tecais. Isso resultou em aumento proporcional da produção de andrógenos. Modelos in vivo, utilizando ratas, responderam de forma semelhante quando a insulina foi administrada, i.e. aumento da atividade da CYP17 e aumento da produção de andrógenos (STEIN et al., 1995; SWAIN et al. 2004). Aparentemente nas células da teca, a presença de insulina é necessária para que ocorra a transcrição do gene da CYP17, porém concentrações extremas tanto de LH quanto de insulina parecem inibir sua transcrição (ZHANG e VELDHUIS, 2004).

Possuindo um efeito direto sobre as aromatases (citocromo P450arom), a insulina também consegue provocar um aumento na sua atividade em meio de cultura, proporcionando dessa forma, uma maior conversão dos andrógenos em estradiol. (DULEBA et al., 1997; DULEBA et al., 1999; VOGE et al., 2004; SELVARAJU et al., 2003). Em células da granulosa de bovinos que foram prétratadas com insulina (SAHMl et al., 2006), houve aumento da transcrição do gene do citocromo P450 arom e da estabilidade pós-transcricional de seu RNAm. Cabras suplementadas com insulina exógena apresentaram níveis plasmáticos de estradiol e andrógenos mais elevados que o grupo controle (Selvaraju et al., 2003).

\subsubsection{INSULINA E DESENVOLVIMENTO FOLICULAR}

A fase inicial do desenvolvimento folicular é marcada por uma intensa comunicação entre o oócito e a única camada de células da granulosa que o rodeia. Uma vez recrutado, o folículo primordial (PROF) sofre algumas transformações morfofisiológicas que culminam com mudanças morfológicas das células da granulosa, que deixam de ser chatas e adquirem formatos cubóides, recebendo agora a denominação de folículo primário (PRIF). Tanto o fator inibidor de leucemia (LIF) quanto o kit-ligant $(\mathrm{KL})$ são importantes mediadores desta transformação e parecem ter seus efeitos potencializados pela insulina. Assim, este hormônio é um corregulador do processo de transição PROF/PRIF (VAN DEN HURK e ZHAO, 
2005). Estudos in vitro realizados com ovários de rato, indicaram que nesta espécie a insulina exerce um efeito estimulatório maior que o IGF-I na transição PROF/PRIF (KEZELE et al., 2002).

Em uma outra fase do crescimento, os folículos multilaminares, no início de seu desenvolvimento, possuem quase que exclusivamente $\mathrm{LHr}$, entretanto com o aumento do número de camadas também surge a dependência dos FSHr para a manutenção do crescimento folicular. Como já discutido anteriormente, a insulina exerce forte influência tanto na androgênese via aumento da atividade da CYP17 (MUNIR et al., 2004), quanto na mitogênese via ativação da MAP quinase (SASAKI, 2003). O somatório desses estímulos favorece a multiplicação das células da granulosa, o aumento da produção de andrógenos nas células tecais e o crescimento oocitário. Neste estágio de desenvolvimento, o andrógeno produzido nas células da teca é um estimulador do aumento no número de $\mathrm{FSHr}$ nas células da granulosa, amplificando assim o efeito do $\mathrm{FSH}$ e possibilitando o crescimento folicular (VAN DEN HURK e ZHAO, 2005). De acordo com Picton e colaboradores (2008), os efeitos fisiológicos proporcionados pela insulina, tornam sua presença imprescindível nos meios de cultivo foliculares para a obtenção de índices aceitáveis de crescimento folicular in vitro.

In vivo, animais que possuem concentração plasmática de insulina maiores tendem a apresentar recrutamento de maior número de folículos dependentes de gonadotropinas, além de reduzida taxa de atresia folicular (COX et al., 1994; MATAMOROS et al., 1991; SELVARAJU et al. 2003). Os resultados desses experimentos também podem ser explicados, pela já abordada, maior pulsatilidade de $\mathrm{GnRH}$ e por consequência de $\mathrm{FSH}$ e $\mathrm{LH}$, e pelo favorecimento do crescimento de células da teca e granulosa. Em cultivo de células da teca intersticial e da granulosa proveniente de folículos com antro de ratos (DULEBA et al., 1997) e de humanos (DULEBA et al., 1998) quando submetido a doses crescentes de insulina, foi observado um significativo aumento numérico dessas células, uma marcante redução no índice de clivagem internucleossomal, redução das alterações morfológicas dos núcleos e aumento no índice de incorporação de DNA, mudanças que indicam redução no grau de apoptose.

De forma geral, a insulina aumenta também a sensibilidade ovariana ao FSH e LH (CHAGAS et al., 2007) e muito provavelmente, tal efeito se deve ao aumento do números de receptores para esse hormônio, uma vez que ratos 
diabéticos apresentam marcante redução da expressão gênica desses receptores nas estruturas ovarianas (BALLESTER et al., 2007).

No caso dos LHr, entretanto, os resultados experimentais são antagônicos. Selvaraju et al. (2003) sugeriram que níveis demasiadamente elevados de insulina podem causar down-regulation nos $\mathrm{LHr}$, culminando em redução na taxa de ovulação. Essa suposição também foi sustentada por Stein et al. (1995) que propôs um modelo de associação entre os receptores de $\mathrm{LH}$ e insulina, em que a cointernalização de um acarreta em redução no número de receptores do outro, explicando assim a redução dos $\mathrm{LHr}$ em ratos que receberam insulina. Controversamente, Sekar et al. (2000) detectaram sinergismo entre LH e insulina no aumento de produção de RNAm para LHr de células da granulosa de suínos previamente luteinizadas. Possivelmente, a divergência entre tais resultados é fruto de condições experimentais além de tempos e intensidade de exposição à insulina distintos.

\subsubsection{INTERAÇÃO INSULINA E OUTROS EFETORES BIOLÓGICOS}

Como anteriormente citado, existem outros efetores que podem interferir na reprodução e ao mesmo tempo sofrer ação da insulina, exemplificando: a IGF, polipeptídeo que apresenta grande homologia estrutural à pró-insulina e, em muitas circunstâncias, função semelhante, é um deles. O tamanho e a similaridade entre o sítio de ligação com seus receptores fazem com que a insulina estimule competitivamente os receptores de IGF-I (IGF-Ir), com afinidade que varia de 1:500 em ratos (CARA e ROSENFIELD, 1998) a 1:100 em coelhos (SANTOS et al. 2004a) em favor da IGF-I. Em seus estudos, Poretsky et al. (1988) apud Stein et al. (1995) encontraram que o aumento da insulina leva a um up-regulation dos receptores de IGF-I, bem como aumento nas concentrações plasmáticas de IGF-I. No caso dos receptores de IGF-II, a insulina parece não exercer estimulação cruzada como ocorre nos de IGF-Ir (SILVA et al., 2009).

Hunter et al. (2004), trabalhando com novilhas em balanço energético positivo observaram que elas apresentavam maiores concentrações plasmáticas de IGF-I, insulina e estradiol, as quais foram correlacionados positivamente com a qualidade dos oócitos quando comparado com os animais em dietas de mantença ou em balanço energético negativo. Uma possível explicação foi um aumento na 
resposta dos centros produtores de gonadotrofinas em resposta aos altos níveis plasmáticos de IGF-I e insulina.

As proteínas ligadoras de IGF (IGFBP) são um grupo de proteínas que normalmente estão associados com a homeostase dos IGFs. Nos folículos dominantes, normalmente os níveis de IGFBP - 2, 4 e 5 encontram-se inversamente correlacionados com o diâmetro folicular (HUNTER et al., 2004; VOGE et al., 2004; FRANCO et al., 2004; FORTUNE et al., 2004).

Estudos em cultivo de células da teca e da granulosa bovina demostraram que a insulina aumenta a concentração de IGFBP 2 e 5, e reduz a de IGFBP 4 (VOGE et al., 2004). Controversamente, Chamberlain e Spicer (2001) e Webb e colaboradores (2006) relataram redução nas concentrações de IGFBP - 2 e 5, e não observaram alterações nas concentrações de IGFBP - 4, também em cultivo de células tecais e da granulosa bovina quando associadas a insulina. Aparentemente, a insulina é capaz de alterar as concentrações foliculares das IGFBPs e, por consequência, das IGFs, porém o seu exato efeito bem como o mecanismo de ação sobre essas proteínas não está elucidado.

Outro hormônio que tem sua produção e secreção fortemente estimulada pela insulina é a leptina, um hormônio produzido primariamente por adipócitos, (SALADIN et al., 1995). Chilliard e colaboradores (2005) relataram que doses únicas de insulina a ruminantes, como estímulo secretor de leptina são mais eficientes in vitro do que in vivo, contudo este efeito não deve ser desconsiderado in vivo. A interação insulina/leptina/reprodução foi avaliada por Swain e colaboradoes (2004) em ratos, e Koutkia e colaboradores (2003) em humanos. Ambos os grupos concluíram que a insulina estimulou a produção de leptina e a ação conjunta destes dois hormônios foi capaz de restabelecer a ciclicidade reprodutiva em indivíduos acíclicos. Ovelhas que receberam dietas ricas em tremoço apresentaram níveis plasmáticos de leptina mais elevados que o grupo controle. Este aumento foi correlacionado positivamente com a taxa de ovulação, com os níveis circulantes de FSH e, negativamente, com os de 17- $\beta$ estradiol (KOSIOR-KORZECKA e BOBOWIEC, 2003). De acordo com Cervero e colaboradores (2006), a leptina pode interferir na reprodução por quatro vias, I) neuroendócrina, em que a leptina estimula a pulsatividade de $\mathrm{GnRH}$ e por consequência de LH e FSH; II) ação direta no ovário, na qual pode reduzir a produção de 17- $\beta$-estradiol; III) na fase pré-implantação embrionária; IV) estimulando a secreção endometrial na fase final do ciclo estral de 
roedores.

\subsubsection{INSULINA E CRESCIMENTO EMBRIONÁRIO}

A adequada nutrição no estágio pré-implantação é fundamental para determinar a sobrevivência e o desenvolvimento embrionário inicial. Até a implantação, o suporte nutricional para o crescimento embrionário é dado, exclusivamente, pela secreção de histotrófos, realizada pelo epitélio e glândulas endometriais (ASHWORTH, 2005).

Altos níveis de insulina são capazes de estimular a capacidade secretória tanto do epitélio quanto das glândulas endometriais através de dois mecanismos, I) pelo aumento da capacidade secretória, via aumento da atividade da Na-K ATPase, que uma vez estimulada pela insulina proporciona maior secreção de sódio transepitelial, e por consequência de histotrófos (DEACHAPUNYAet al, 1999); II) via efeito mitogênico, estimulando a adenogênese e o crescimento epitelial do endométrio (GRAY et al., 2001).

In vivo, a baixa concentração de insulina plasmática de ovelhas foi associada por Davies-Morel e Beck (2003) com uma pequena captação uterina de glicose e aminoácidos, resultando na redução da secreção dos histotrófos nas fases iniciais de gestação.

Mesmo não produzindo insulina na fase pré-implantação, os embriões podem ter acesso à insulina através de secreções do oviduto, fato demonstrado por Heyner e colaboradores (1989) e, muito provavelmente também, pelo fluido uterino (KAYNE et al., 1992).

Atuando diretamente sobre o embrião, a insulina estimula tanto a captação de glicose quanto influencia o turnover proteico em favor do anabolismo. Este hormônio além de favorecer o anabolismo proteico pelos mecanismos já abordados, e no caso de embriões, também pode estimular a absorção de macroproteínas por endocitose, como foi observado no caso da albumina sérica bovina por embriões de rato cultivados in vitro (KAYNE et al., 1992).

No caso da captação de glicose, Santos e colaboradores (2004 b) relataram que a presença de Ir e de proteínas GLUT são importantes para o bom desenvolvimento embrionário. Blastocistos bovinos expressaram a produção de 
RNAm para as GLUT 1 e 4 (SANTOS et al., 2000), e embriões de coelho apresentam proteínas GLUT 1, 3, 4 e 8 e Ir (SANTOS et al., 2004 a;b ). De acordo com tais autores, além do aumento da captação de glicose, os Ir, quando estimulados, demonstraram grande função mitogênica, antiapoptótica e anabólica na massa interna de célula do blastocisto, o que resultou em maior desenvolvimento embrionário.

Os efeitos benéficos da insulina observados in vitro sobre o crescimento embrionário sinalizam reprodutividade in vivo. Em experimento realizado por Mann e colaboradores (2003), observou-se que os embriões oriundos de vacas com níveis plasmáticos superiores de insulina se mostravam mais alongados e com maior produção de interferon TAU entre $016^{\circ}$ e $\circ 18^{\circ}$ dias pós-fecundação. Como consequência, esses embriões cobriam uma maior área de endométrio e inibiram de forma mais eficiente a produção de protaglandina F2 $\alpha$ (PGF2 $\alpha$ ) nos cornos ipsolaterais à ovulação e apresentaram menores taxas de reabsorção fetal prematura.

\subsubsection{ESTRATÉGIAS DE USO DA INSULINA VISANDO AUMENTAR A PRODUÇÃO EMBRIONÁRIA E OS ÍNDICES REPRODUTIVOS}

As respostas de estudos in vitro, no controle da função ovariana, da esteroidogênese e desenvolvimento embrionário têm despertado o interesse de uso estratégico de insulina exógena ou mesmo o estímulo do aumento de sua produção endógena, visando incrementar os índices reprodutivos.

Gong e colaboradores (2002) e Garnsworthy e colaboradores (2008) fizeram uso de dietas ricas em carboidratos para vacas leiteiras com o intuito de aumentar a concentração plasmática de insulina. No primeiro experimento, os autores conseguiram antecipar a primeira ovulação pós-parto; no segundo, os autores concluíram que a insulina bem como a relação insulin/glucagon favorece 0 crescimento folicular pré-ovulação.

Em suínos, a administração exógena de insulina visando aumentar a taxa de ovulação foi avaliada por COX e colaboradores (1987), que administraram doses de $0,4 \mathrm{UI} / \mathrm{Kg}$ de peso vivo de insulina por até dez dias, o que resultou em aumento da taxa ovulatória e em maiores concentrações plasmáticas de LH e FSH. Outra estratégia também utilizada em suínos foi a adotada por Almeida e colaboradores 
(2001) para mitigar o efeito negativo latente sobre a reprodução de curtos períodos de restrição alimentar, ministrando dose de $0,8 \mathrm{Ul} / \mathrm{kg}$ de peso vivo de insulina durante oito dias. Os animais tratados apresentaram maior taxa de ovulação e maior número de embriões. Estratégia semelhante foi proposta por Hax e colaboradores (2008) para melhorar o recrutamento e o crescimento folicular em ovinos. As ovelhas tratadas receberam oito aplicações intervaladas de 0,25 UI/kg de peso vivo de insulina durante quatro dias, porém não foi encontrada diferença entre os tratamentos e os autores atribuíram esse resultado ao pequeno número de animais utilizado neste experimento. O mesmo grupo de pesquisa em experimento semelhante identificou que o grupo tratado com insulina apresentou redução plasmática de NEFA e de uréia e aumento da concentração de glicose e neste caso houve uma correlação positiva $\left(\mathrm{R}^{2}=0,4\right)$ com diâmetro folicular (SILVA NETO et al., 2008).

O usos de insulina, concomitante ao processo de superovulação, foi utilizado em cabras com o intuito de aumentar o número de embriões. Para tanto, foram aplicados $0,2 \mathrm{Ul} / \mathrm{kg}$ de peso vivo de insulina durante o processo superovulatório, resultando em maior produção de progesterona e taxa de recrutamento folicular. Porém esses acréscimos não refletiram em maior número de embriões e corpos lúteos (SELVARAJU et al., 2003). O uso de insulina durante o período de estro e na fase pré-implantação de cabras, acarretou em incremento da taxa de gestação gemelar e da produção de progesterona (SUGUNA et al., 2009).

Sarath e colaboradores (2008), propuseram o uso insulina para conseguir estimular o retorno à ciclicidade de cabras acíclicas. O retorno à ciclicidade foi conseguido em $71 \%$ dos animais com a administração de $0,2 \mathrm{UI} / \mathrm{kg}$ de peso vivo de insulina durante cinco dias.

\subsubsection{INDUÇÃO DO STATUS DE HIPOINSULINEMIA EM OVINOS}

A indução do diabetes, para fins de estudo do metabolismo de carboidratos, avaliação dos efeitos da insulina e elucidação das lesões pré-diabéticas, pode ser conseguida com 0 uso de drogas diabetogênicas como o alloxano, a estreptozotocina e a ditizona, que induzem o aparecimento de um quadro de hipoinsulinemia irreversível, fruto de uma pancreatite com destruição relativamente seletiva das células $\beta$ pancreáticas (CANDY et al., 1982). Outros mecanismos a 
serem considerados são a pancreactomia e o uso de anticorpo anti-insulina, talvez o único irreversível (CARVALHO et al., 2003).

As drogas diabetogênicas promovem uma inibição parcial da atividade da cobre/zinco superóxido dismutase (SOD), uma enzima que se encontra em grande quantidade nas células $\beta$ e cuja finalidade é inativar os radicais de oxigênio (CANDY et al., 1982).

O alloxano é uma pirimidina altamente instável e é estruturalmente bastante semelhante ao ácido úrico e à glicose, possuindo uma meia vida plasmática de aproximadamente noventa segundos. A potencial desvantagem dessa droga é que ela pode apresentar toxicidade ao rim, fígado e pulmão, mas nada foi observado por Miodovinik et al.. (1989) que, durante o período experimental com uma única dose de $40 \mathrm{mg} / \mathrm{kg}$ de peso vivo intravenosa (I.V.), obtiveram 100\% de diabetes em ovelhas em final de gestação. Leenanuruksa e McDowell (1988 a;b) conseguiram êxito na indução do diabetes em apenas $75 \%$ das ovelhas tratadas com $50 \mathrm{mg} / \mathrm{kg}$ de peso vivo I.V.

A estreptozotocina é mais específica e por isso menos tóxica que o alloxano, mas seu custo de mercado é cerca de cem vezes superior, restringindo muitas vezes seu uso para animais de médio a grande porte. O estado diabético com esse fármaco foi conseguido em ovelhas com a aplicação única de uma dose intravenosa de $50 \mathrm{mg} / \mathrm{kg}$ de peso vivo em todos os animais tratados (DICKISON et al., 1991, a;b).

Em experimento de Leenanuruksa e McDowell (1988 a), durante as primeiras quatro horas que sucederam à administração de alloxano, ocorreu uma redução da insulina plasmática a concentrações inferiores aos níveis basais, com uma consequente hiperglicemia. Doze horas após o início do procedimento, a insulina atingiu uma concentração quatro vezes superior à linha de base e começou a declinar lentamente durante as oito horas subsequentes, quando se estabilizou em valores de $30 \%$ da linha de base. A glicose apresentou comportamento exatamente oposto à insulina, provavelmente devido à morte e degranulação das células $\beta$. Ao término deste experimento os autores concluíram que o modelo ovino alloxanodiabético serve para estudar o efeito da insulina no metabolismo. 


\section{2 DESENVOLVIMENTO DE UMA FORMULAÇÃO NANOESTRUTURADA DE INSULINA}

\subsubsection{INTRODUÇÃO}

A insulina juntamente com o glucagon são os dois principais responsáveis pela homeostasia da glicose sanguínea. $\mathrm{O}$ aumento dos níveis plasmáticos de insulina culmina com a redução da glicose circulante. Em contrapartida, o glucagon possui uma função oposta à insulina, promovendo a mobilização das reservas hepáticas de glicogênio e conseguindo assim a normoglicemia (WATANABE et al., 1998).

Em condições normais, insulina endógena tem tempo de depuração de 10 a 15 minutos, circulando livremente no plasma sanguíneo (GORLA JUNNIOR et al., 2001). O conhecimento desses parâmetros nas terapias com insulina é fundamental, uma vez que a administração desse hormônio em condições de hipoglicemia ou em sobredose, pode causar hipoglicemia não fisiológica prolongada. Clinicamente tais falhas são externadas em indivíduos prenhes como choque hipoglicêmico, embriotoxicidade, teratogenia e morte embrionária, aborto, coma e eventualmente morte da genitora (EMEA, 2002).

Para contornar esses problemas, existem no mercado diferentes tipos de formulações de insulina que apresentam padrões distintos de absorção e ação pósinjeção. O padrão de absorção e ação de uma formulação é regido por diversos fatores, dentre eles o grau de polimerização dos monômeros de insulina (FERNANDES et al., 2007), grau de protamina ou de zinco e o tipo de análogos de insulina, e.g. lispro, aspart, glargine e insulinas aciladas a ácidos graxos (GUERICH, 2002; GHOUGH, 2007). Mais recentemente, sistemas micro/nanométricos baseados em polímeros e lipossomas foram propostos para simultaneamente reduzir o pico de absorção e aumentar o tempo de liberação da insulina e seus análogos, ampliando assim as opções de padrões de absorção e ação desse hormônio (BOYLE, 2008).

A administração de apenas uma dose de insulina para maximizar a reprodução aparentemente é ineficaz (CHILLIARD et al., 2005). Experimentos que demostraram efeitos positivos da insulina nos índices reprodutivos, fizeram uso por cinco dias ou mais da suplementação deste hormônio (ALMEIDA et al., 2001; 
SARATH et al., 2008).

Em produção animal, dois pontos são importantes no manejo de biotécnicas de reprodução assistida, a redução da mão de obra e do estresse animal. Nesse contexto, o desenvolvimento de uma formulação nanoestruturada de insulina pode simultaneamente mitigar o risco de choques hipoglicêmicos e reduzir o estresse animal e os custos de mão-de-obra por reduzir o número de aplicações quando se aventar seu uso. Pode ainda ser utilizada como modelo de estudo para liberação sustentada ou permeação de mucosa de hormônios proteicos, como por exemplo FSH e eCG, já que a manutenção da atividade biológica da insulina é facilmente mensurada pela queda da glicemia.

\subsubsection{SISTEMAS NANOESTRUTURADOS EM LIBERAÇÃO SUSTENTADA DE FÁRMACOS}

Em farmacologia, sistema nanoestruturados de liberação sustentada são caracterizados como partículas coloidais que apresentem pelo menos uma das dimensões inferior a $1000 \mathrm{~nm}$, sendo elas capazes de carrear e/ou direcionar um princípio ativo dentro de um sistema biológico (SOPPIMATH et al., 2001, COUVREUR et al., 2002 e REIS et al., 2006).

Com o uso de nanopartículas poliméricas, tem-se conseguido a liberação controlada e o direcionamento passivo de drogas para células específicas, como fagócitos e células tumorais, ou até mesmo para órgãos como baço, fígado e pulmão (FORMARIZ et al., 2004; O'DONNELL e MCGINITY, 1997). Ao imobilizar a droga no interior da nanopartícula também se consegue isolá-la da solução, o que em alguns casos acaba conferindo maior estabilidade à substância aprisionada (SOPPIMATH et al., 2001; O'DONNELL e MCGINITY, 1997). Formariz e colaboradores (2004) relataram que o uso de nanopartículas pode camuflar algumas propriedades físicoquímicas de drogas, sem causar alteração no seu mecanismo de ação. Um exemplo é a melhoria observada na veiculação aquosa de quimioterápicos lipofílicos. Outro benefício conseguido com o uso de sistemas nanoestruturados é a redução da toxicidade (figura 1) do composto encapsulado, fenômeno que ocorre porque as moléculas de princípio ativo ficam entremeadas às que compõem a nanopartícula, dificultando o alcance do DL50 do tecido alvo (COUVREUR et al., 2002). 
As nanoesferas são formadas por uma matriz poliméricas na qual o princípio ativo se encontra disperso no polímero e/ou adsorvido à sua superfície, entre as interfaces de fase. Já as nanocápsulas são formadas por um núcleo oleoso líquido revestidas por uma parede polimérica e, em função das características do princípio ativo encapsulado, este pode encontrar disperso no núcleo oleoso, na interface óleo polímero e/ou na interface polímero meio externo (LEGRAND et al, 1999, GUTERRES et al, 2006).

O processo de liberação do princípio ativo nas nanoesferas se dá por difusão através do polímero e vai se acelerando à medida em que a esfera sofre o processo de erosão sendo, portanto, dependente da área exposta. Em contrapartida, nas micro-nanocápsulas um processo de difusão e ou osmose ocorre em decorrência de uma poração na membrana polimérica; o efeito final é uma liberação sustentada do princípio ativo, como observado na figura 1 (BRANNONPEPPAS,1997; SOPPIMATH et al., 2002).

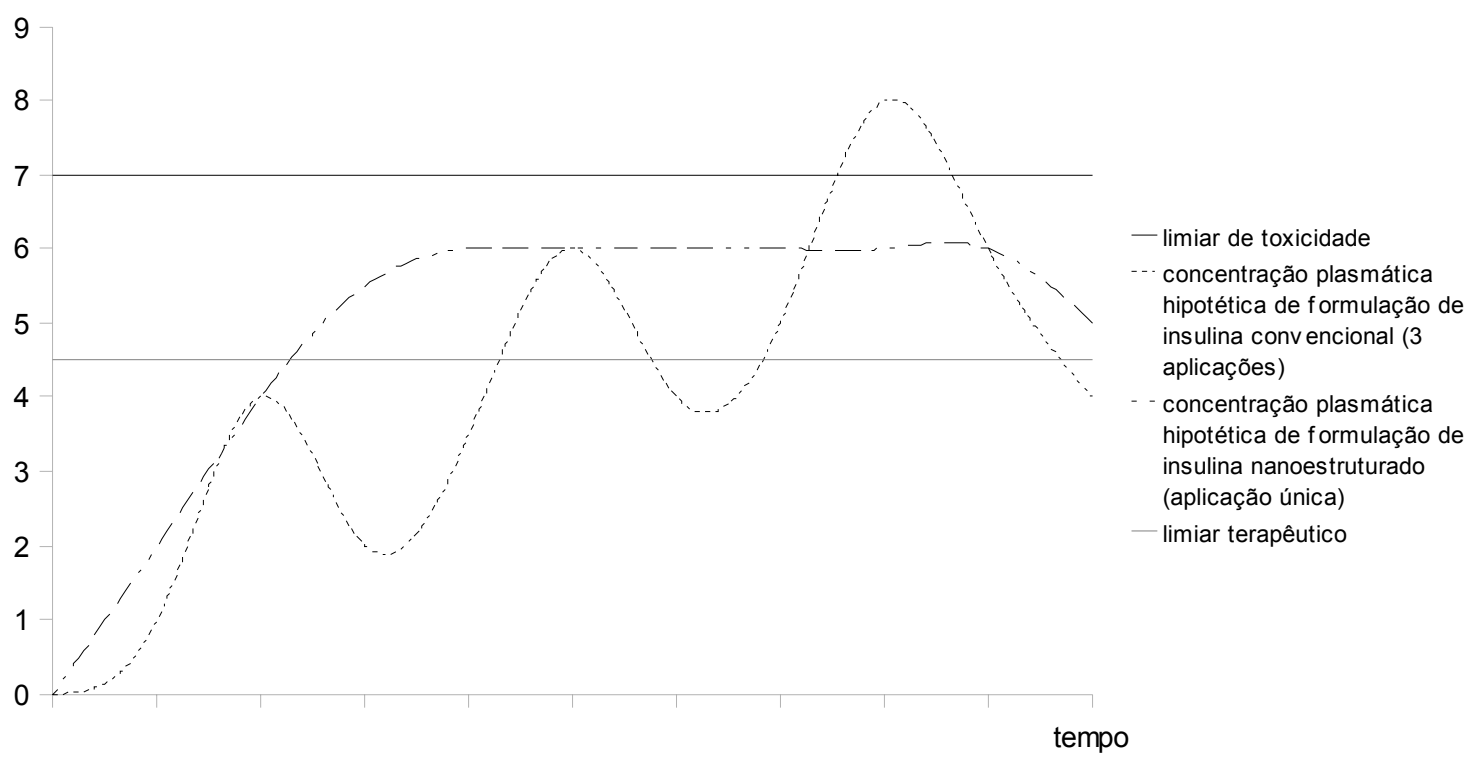

Figura1: Comparação teórica de uma formulação de insulina convencional e uma nanoestruturada com liberação sustentada. Eixo $Y$ refere-se a valores hipotéticos de concentração plasmática de insulina.

Duran e colaboradores (2006) relataram que a velocidade e degradação de um polímero pode ser afetada pela sua composição química, peso molecular e polidispersão, caráter hidrofóbico/hidrofílico, mecanismo de hidrólise (não catalítica, catalítica e ou enzimática), estrutura cristalina ou amorfa do polímero, grau de porosidade, características físicas como tamanho e forma, fatores físico-químicos e local de implante, podendo variar de horas a meses. 
Um universo bastante grande de substâncias já foi encapsulada, usufruindo assim de algum benefício propiciado pelo polímero formador da nanopartícula: antineoplásicos, como a doxorubicina, foram encapsulados (NÉMATI et al., 1996), visando à liberação controlada e a redução dos efeitos colaterais; partículas virais foram apresentadas de forma mais eficiente ao sistema imune (KREUTER et al., 1975); hormônios protéicos como a insulina foram protegidos para evitar proteólise digestiva e posteriormente apresentaram absorção intestinal (WATNASIRICHAIKUL et al., 2000; LIN et al., 2007).

Nanopartículas podem ser feitas por diferentes técnicas e com inúmeros polímeros, mas uma atenção especial deve ser dada aos polímeros biodegradáveis que, através de hidrólise das ligações ésteres e ou ação enzimática, se transformam em metabólitos inócuos que podem ser excretados ou reutilizados pelo metabolismo celular (LEGRAND et al., 1999, DURAN et al., 2006). Os polímeros utilizados para nanoencapsulação podem ser divididos em dois grandes grupos, polímeros hidrofílicos e hidrofóbicos (HANS e LOWMAN, 2002).

O encapsulamento direto de proteínas com polímeros hidrofóbicos, isto é

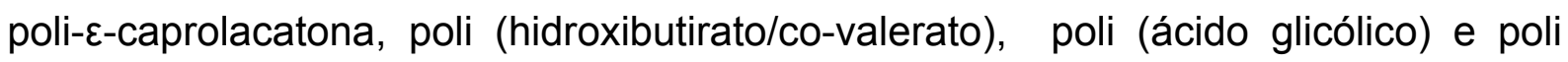
(ácido lático) e seus copolímeros é muito pouco eficiente. Para melhorar a eficiência de encapsulamento, pode-se trabalhar em sistemas de dupla emulsão, sólido/óleo/água ou água/óleo/água com remoção ou difusão do solvente orgânico (SOPPIMATH et al., 2001).

Fármacos hidrofílicos e proteínas, normalmente são mais eficientemente encapsulados por polímeros também hidrofílicos, visto que interações elétricas podem ocorrer entre os grupos funcionais da cadeia polimérica e a proteína (REIS et al, 2006b). Dentre os polímeros utilizados, pode-se destacar a permeação da barreira hematoencefálica com nanopartículas de albumina/lipoproteína, o encapsulamento de insulina com quitosana (LIN et al., 2007), de BSA com alginato (WELLS e SHEARDOWN, 2007).

\subsubsection{QUITOSANA}

A quitosana é um polissacarídeo linear derivado da quitina, talvez o segundo 
biopolímero natural mais abundante, ficando atrás apenas da celulose. Na natureza a quitina é comumente encontrada no exoesqueleto de crustáceos e de insetos ou produzidas por fungos (DENKBAS e OTTENBRITE, 2006 ).

Industrialmente, a quitosana é obtida a partir da quitina após exaustiva desacetilação do grupamento acetoamino que, sob condições de temperatura elevada e ambiente alcalino, é convertido em um grupamento amino (DENKBAS e OTTENBRITE, 2006). Comercialmente, as quitosanas com peso molecular variando entre 3,8 e 20 kDa e grau de desacetilação entre 66 e 95\% são mais facilmente encontradas que os demais tipos, o que explica sua maior utilização em produtos no mercado (AGNIHOTRI et al., 2004). O constante aumento na procura e na prospecção de novos produtos à base de quitosana são decorrentes de suas varias propriedades biológicas, como por exemplo: biodegradabilidade, biocompatibilidade, efeito hemostático, atividade analgésica, atividade antitimoral, mucoadesividade, permeabilidade de mucosa, atividade anticolesterolêmica, atividade antimicrobiana e atividade antioxidante (AGNIHOTRI et al., 2004; BARROS et al., 2006; MASOTTI e ORTAGGI, 2009). Com isso, este biopolímero acumula aplicações nas áreas biomédicas de cicatrização de feridas, sistemas de liberação sustentada para fármacos e genes, engenharia de tecidos, ingredientes alimentares, biocatálise e imobilização de enzimas (RINAUDO, 2006; ARANAZ et al., 2009).

Ambas, quitosana e quitina, estruturalmente são muito semelhantes, apresentam uma ligação $\beta(1-4)$ entre os o monossacarídeos e diferem entre si exclusivamente no grau de desacetilações, i.e. quantidade de monômeros desacetilados em sua cadeia. Quando o grau de desacetilação supera $50 \%$, o polímero recebe a denominação de quitosana. Em contrapartida, biopolímeros com grau de desacetilação inferior a este valor são denominados de quitina (BARROS et al., 2006). A figura 2 exemplifica uma unidade monomérica acetilada e uma desacetilada. De acordo com Aranaz e colaboradores (2009), o grau de desacetilação da quitosana é o fator que mais interfere em sua caracterítica fisicoquímica e farmacológica, contudo o peso molecular e o grau de cristalinidade também devem ser considerados. 


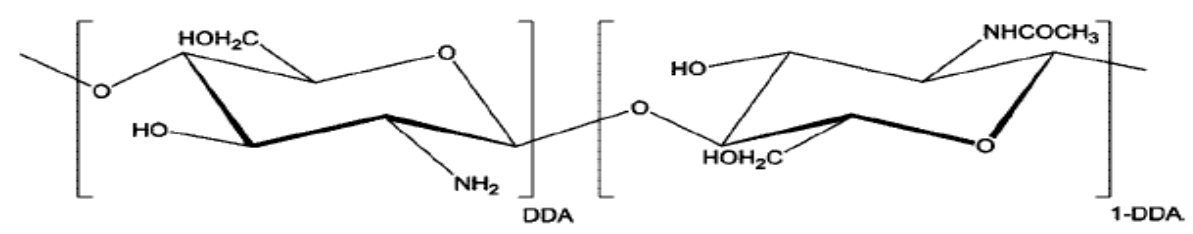

Figura 2: Cadeia polimérica de quitosana, monômero da esquerda desacetilado e monômero da direita acetilada. Adaptado (PAYET e TERENTJEV, 2008).

No caso da quitina, existem três formas cristalinas: $\alpha, \beta$ e $\gamma$-quitina (WONG, 2009). Po sua vez, a quitosana é um polímero semicristalino que pode apresentar um polimorfismo de cristalinidade dependendo de seu estado físico (ARANAZ et al., 2009). Em ambos os polímeros, quanto menor o grau de desacetilação maior será a cristalinidade, i. e. quitina com $0 \%$ de desacetilação está totalmente na forma cristalina, enquanto que a quitosana $100 \%$ desacetilada se encontra completamente na forma amorfa (ARANAZ et al., 2009; WONG, 2009). Isso ocorre por que o decréscimo na intensidade de desacetilação torna a cadeia mais rígida e esticada, o que favorece sua organização na forma de mais cristalina (RINAUDO, 2006). O enrijecimento da cadeia de quitosana pode afetar o comportamento reológico das moléculas quando em solução ao formar pontes de hidrogênio intercadeias e assim formar multímeros que acabam por pertubar todas as características do polisacarídeo (WONG, 2009).

A presença de grupamentos aminos livres (figura 2) fazem da quitosana uma base fraca, com pKa variando entre 6,2 e 7 e insolúvel em solventes orgânicos ou soluções aquosas com pH alcalino (LIN et al., 2007). Sob condições ácidas, os grupamentos aminos livres $\left(-\mathrm{NH}_{2}\right)$ ficam protonados $\left(-\mathrm{NH}_{3}{ }^{+}\right)$e thes conferem solubilidade em meio aquoso, transformando-se em um policátion. Assim o grau de desacetilação é um dos fatores que determina a solubilidade da quitosana em meio aquoso (LIN et al., 2007), entretanto sua solubilidade em ácidos inorgânicos é limitada quando comparada a ácidos orgânicos (SINGLA e CHAWLA, 2001). Adicionalmente, sabe-se também que a forma com que os grupamentos acetil se distribuem ao longo da cadeia polimérica, bem como os distintos ácidos em mesmo $\mathrm{pH}$ podem influenciar as propriedades físicas da solução de quitosana (SINGLA e CHAWLA, 2001; RINAUDO, 2006). 
Com relação ao tamanho de cadeia, a quitosana pode ser classificada em alto peso molecular, variando entre 700 e 1000 kDa; médio peso molecular, 150 a 700 kDa; e baixo peso molecular com menos de 150 kDa (WONG, 2009). A influência do peso molecular na determinação da vicosidade da quitosana em solução aquosa é de grande importância na determinação do seu comportamento bioquímico e biofarmacológico. De maneira geral, quitosanas de baixo peso molecular em solução apresentam baixa viscosidade que tende a aumentar com o incremento no tamanho da cadeia do polimero (SINGLA e CHAWLA, 2001). Todavia outras variáveis da solução como, $\mathrm{pH}$, temperatura e a força iônica podem influenciar nas características do sistema (WHONG, 2009).

A velocidade de biodegradação da quitosana está intimamente relacionada ao ambiente em que ela se encontra, ao tamanho da cadeia polimérica e ao seu grau de desacetilação (ARANAZ et al., 2009). A propensão à degradação da quitosana aumenta com o decrécimo no grau de deacetiliação, no entanto, se os grupamentos acetil se concentram em uma determinada parte da cadeia, o processo se torna bastante lento (KOFUJl et al., 2005). Quando inoculada em mamíferos, a quitosana sofre ataque de enzimas proeolíticas como a lisosima, papaina e pepsina, porém a sinética de degradação enzimática é bastante lenta (PANGBURN et al., 1982) e acaba por liberar oligossacarídeos de diferentes tamanhos que podem ser incorporados em glicosaminoglicanos e em glicoproteínas, metoabolisados ou excretados (AGNIHOTRI et al., 2004).

A biocompatibilidade e baixa toxicidade da quitosana a torna um polímero de uso bastante difundido, uma vez que seu $\mathrm{DL}_{50}$ em ratos é de $16 \mathrm{~g} / \mathrm{kg}$ de peso vivo (AGNIHOTRI et al., 2004). A biocompatibilidade, todavia, pode ser afetada por quitosanas que apresentem velocidade de degradação muito acelerada, já que durante este processo podem ser produzidos aminoglicanos capazes de estimular uma resposta inflamatória aguda quando acumulados (PANGBURN et al., 1982; KOFUJI et al., 2005; ARANAZ et al., 2009).

\subsubsection{QUITOSANA EM SISTEMAS DE LIBERAÇÃO SUSTENTADO}

Os sistemas de liberação sustentada em medicina veterinária possuem grande impacto econômico por reduzir o manejo e o estresse animal (MEDLICOTT 
et al., 2004). No caso de humanos, o foco vai além da redução do número de aplicações, buscando também o desenvolvimentos de novas vias de aplicação para os fármacos tradicionais (ARANAZ et al., 2009).

Na indústria farmacêutica, devido as características biológicas já discutidas, a quitosana ganhou espaço para o desenvolvimento de sistemas de liberação sustentado na forma de micro e nanopartículas, filmes, peletes, hidrogéis e na forma de moléculas conjugadas por síntese. De acordo com Kofuji e colaboradores (2005), a eleição do tipo adequado de quitosana é fundamental para se obter o efeito de liberação sustentada, melhoria na eficiência terapêutica ou mesmo redução da toxicidade. Para tanto, três fatores assumem elevada importância da quitosana: a pureza, seu grau de desacetilação e seu peso molecular.

O grau de desacetilação determina a capacidade de complexação, quelação ou de efetuar retuculação da quitosana (RINAUDO, 2006). Com o aumento do grau de desacetilação, maior número de grupamentos aminos ficam livres o que favorece a intensificação do processo de reticulação (DRAGHET, 1996). Ao intensificar o processo de reticulação consegue-se formar particulas menores e de superfície mais lisa, mais compacta e com menor capacidade de hidratação (DRAGHET, 1996; GUPTA E JABRAIL, 2007; ARANAZ et al., 2009). Ademais, essa variável exerce grande influência na cristalinidade e hidrofobicidade da quitosana, que acabam por interferir nas interações hidrofóbicas e ou eletrostática que controlam o encapsulamento e o comportamento de liberação da matiz polimérica (DRAGHET, 1996). Assim, a eficiência de encapsulamento vai depender não só do tipo de quitosana, mas também das características da molécula a ser encapsulada (MASOTTI e ORTAGGI, 2009).

Gupta e Jabrail (2007) avaliaram o efeito do peso molecular no processo de formação de microesferas de quitosana reticuladas com glutaraldeido. Tais autores, constataram que o aumento do peso molecular da cadeia polimérica culmina com a redução do tamanho e da rugosidade das esferas. Essas observações foram atribuídas a uma maior empacotamento molecular e reticulação intra e intercadeias poliméricas. A sinética de formação das micropartículas acabou por interferir na eficiência de encapsulamento do centchoman, indicando que a quitosana de baixo peso molecular foi menos eficiente que as de médio e alto peso molecular. Durante o processo de formação de micro e nanopartículas, quitosanas de baixo peso 
molecular necessitam de maior energia de ativação para a efetivação da reticulação, o que torna o processo mais lento e pode reduzir a eficiência de encapsulamento (MI et al., 2000).

Atenção especial tem sido dada à quitosana para o desenvolvimento de dispositivos que façam uso de suas características de mucoadesão e permeação de mucosa. O mecanismo de transposição da mucosa intestinal por nanopartículas de quitosana ainda não está bem definido, entretanto, segundo Jung e colaboradores (2000), Masotti e Ortaggi (2009) e Wong (2009), elas conseguem este feito através de três prováveis mecanismos: I. Via paracelular, no qual o polímero pode alterar a permeabilidade das junções firmes, após uma prévia ligação a células associadas. Por essa rota dificilmente se absorvem partículas com diâmetro superior a 100nm; II. Endocitose mediada por receptores (EMR), basicamente ocorre após a saturação dos receptores e com gasto de energia. Partículas de até 500nm são absorvidas por esta via; III. Endocitose absortiva, independe de receptores e ou especificidade do ligante, ocorre prioritariamente na base das microvilosidades pelas células $M$. Aparentemente esse processo tem início após a adsorção da nanopartícula à membrana e interações inespecíficas como pontes de hidrogênio e interações hidrofóbicas. Dessa forma, a absorção de nanopartículas pode ocorrer tanto por enterócitos quanto por células $M$, sendo mais eficiente no segundo tipo celular e em regiões associadas a folículos linfóides como placa de Payer e apêndice.

\subsubsection{PREPARO DE NANOPARTÍCULAS DE QUITOSANA}

Existem inúmeras metodologias para produção de nanopartículas de quitosana Dentre as técnicas mais utilizadas, as de emulsão e remoção da fase oleosa e a de geleificação ionotrópica se destacam pela facilidade e baixo custo de produção de nanopartículas, enquanto a técnica de spray drying se mostra muito promissora por atingir facilmente uma escala industrial, porém ainda apresenta limitações para produção de partículas com tamanho inferior a $1000 \mathrm{~nm}$ (SOPPIMATH et al., 2001; REIS et al., 2006; MASOTTI e ORTAGGI, 2009).

A técnica de emulsão e remoção da fase oleosa pode ser utilizada tanto com agentes reticulantes, quanto com agentes coacervantes para confeccionar nanopartículas. Para tanto, prepara-se uma emulsão água em óleo $(\mathrm{A} / \mathrm{O})$ por ação 
de um homogeneizador de alta potência, na qual o princípio ativo e a quitosana estão dispersos na fase aquosa e o componente oleoso perfaz a fase contínua. A estabilização da emulsão pode ser conseguida com o auxílio de distintos surfactantes. Ainda sob vigorosa agitação, um agente reticulante ou uma solução alcalina é adicionada à emulsão. A coalescência das gotículas em emulsão ao agente reticulante ou à solução aquosa com pH alcalino resultará na formação das nanopartículas (PAYET e TERENTJEV, 2008).

Uma variação desta técnica pode ser conseguida com a mescla de duas emulsões $\mathrm{A} / \mathrm{O}$ sob vigorosa agitação. Na fase aquosa de uma das emulsões, se encontram quitosana e princípio ativo, enquanto na fase aquosa da outra emulsão se encontra o agente reticulante, ou uma solução de $\mathrm{pH}$ alcalino. A coalescência entre as gotas formam as nanopartículas (AGNIHOTRI et al., 2004).

O processo de geleificação ionotrópico talvez seja a técnica mais difundida de confecção de nanopartículas a partir da quitosana. Baseia-se na complexação eletrostática de macromoléculas com cargas opostas. Na geleificação ionotrópica, a quitosana é protonada após sua solubilização em uma solução aquosa ácida. Posteriormente esta solução é vertida gota a gota em uma segunda solução sob agitação e que contenha um poliânion (SOPPIMATH et al., 2001).

Os poliânions mais utilizados na geleificação ionotrópica com a quitosana são o tripolifosfato, utilizado por Calvo e colaboradores (1997) e o sulfato de dextran, por Chen e colaboradores (2007), ambos para encapsular albumina sérica bovina, o ácido hialurônico para promover a liberação sustentada de gentamicina (LIM et al., 2000) e o alginato para proteger e propiciar uma liberação sustentada de insulina (SARMENTO et al., 2007).

O processo completo de complexação entre policátions e poliânions envolve três etapas, I) formação do um complexo primário. Nesta etapa estão envolvidas forças de ligação secundárias, como as forças de Coulombo; II) formação do processo intracomplexo, no qual ocorre um rearranjo das cadeias poliméricas com a correção das distorções de cadeia. Neste momento, pode ocorrer formação de novas ligações; III) agregação intercomplexos secundários, regida por interações hidorfóbicas (DIMITRIU e CHORNET, 1998).

Pela técnica de spray draying normalmente são confecionadas partículas 
com tamanho variando entre 1 e 10 micrometros, que podem ser reticuladas ou não (MASOTTI e ORTAGGI, 2009). Para a confecção das partículas é conseguida com a injeção de uma solução contendo o polímero sob pressão através de um bico atomizador, gerando gotículas de solução, que em contato com um cotrafluxo de ar aquecido promove uma rápida evaporação da água, formando assim as partículas (AGNIHOTRI et al., 2004).

\subsubsection{NANOPARTÍCULAS CONTENDO INSULINA}

Formulações de liberação sustentada com nanopartículas permitem 0 controle da glicemia em pacientes diabéticos por um longo período de tempo (REIS et al., 2007; WONG, 2009). Liu e colaboradores (2007) confeccionaram nanopartículas de poliácido latico-co-glicólico pela técnica de dupla emulsão e evaporação do solvente. O diâmetro das partículas variou entre 367 e 615 nm, com eficiência de encapsulamento da insulina de até $72 \%$. Posterior a sua confecção, as nanopartículas foram incorporadas a um hidrogel de álcool polivinílico e este sistema apresentou liberação acumulativa in vitro de $70 \%$ após 240 horas de ensaio. In vivo, após a administração intraperitonial de $20 U \mathrm{l} / \mathrm{kg}$, obteve-se a redução da glicemia por período superior a 12 horas e a significativa redução da toxicidade da insulina.

Ainda objetivando administração parenteral, Zang e colaboradores (2008) encapsularam a insulina com nanopartículas de quitosana PEG-ladas reticuladas com tripolifosfato. As nanopartículas apresentaram diâmetro variando entre 160 e $300 \mathrm{~nm}$ e eficiência de encapsulamento de até $65 \%$ e liberação acumilativa in vitro próxima a $70 \%$ nas primeiras 24 horas, com a partículas que continham maior quantidade de insulina, apresentando um pico de liberação inicial maior.

Outra estratégia para utilização de nanopartículas contendo insulina é a sua administração via nasal. Fernandez-Urrusuno e colaboradores (1999) produziram nanopartículas catiônicas de quitosana hidroclorídrica e tripolifosfato com tamanho variando entre 311 e 407 nm com eficiência de encapsulação de até 96\%. Estas partículas apresentaram $100 \%$ de liberação após duas horas de incubação em tampão fosfato e, quando administradas via nasal induziram uma queda na glicemia de $45 \%$ em função da linha de base. 
Tahara e colaboradores (2008) confeccionaram uma nanodispersão sólido em óleo, contendo a insulina como fase sólida objetivando sua permeação cutânea. As nanopartículas com diâmetro médio de $257 \mathrm{~nm}$ após $48 \mathrm{~h}$ de incubação conseguiram penetrar a pele, espalhando-se pelo tecido subcutâneo, epiderme e derme.

O encapsulamento da insulina pela técnica de geleificação ionotrópica foi avaliada por Lin e colaboradores (2007). Para tanto, o ácido poliglutâmico foi utilizado como agente reticulante, produzindo nanopartículas com diâmetro médio variando entre 114 e $302 \mathrm{~nm}$ e potencial Zeta variando entre $-23,7$ e $+33,4 \mathrm{mV}$. Tanto potencial Zeta quanto tamanho variaram em função das relações quitosana/ácido poliglutâmico. A eficiência máxima de encapsulamente foi de 56,8\% e, após um intervalo de 4 horas de ensaio de liberação in vitro, $90 \%$ da insulina havia sido liberada em pH 7,4. Em ensaios in vivo, duas horas após a ingestão das nanopartículas foi observada a queda da glicemia, atingindo valor mínimo em cinco horas pós ingestão e se mantendo baixo por cinco horas.

O tripolifosfato foi utilizado como agente reticulante durante o processo de confecção de nanopartículas por Pan e colaboradores (2002). As partículas produzidas apresentaram tamanho variando entre 265,3 e 387,4 nm com potencial Zeta superior a $+27,3 \mathrm{mV}$ e eficiência de encapsulamento mínima de $59,6 \%$. A administração oral resultou em redução da glicemia por até 24 horas. Outro agente reticulante, o sulfato de dextran, também pode ser utilizado para encapsular insulina (SARMENTO et al., 2006). Nesse trabalho for foram produzidas nanopartículas com tamanho entre 479 e $910 \mathrm{~nm}$, no qual as menores partículas apresentaram eficiência de encapsulamento de $54,7 \%$, enquanto que as maiores de $96,4 \%$. O mesmo grupo de pesquisa (SARMENTO et al., 2007) também produziu nanopartículas carreadoras de insulina baseada na reticulação da quitosana com o alginato. $O$ resultado foi a produção de partículas com diâmetro médio de $750 \mathrm{~nm}$ e potencial Zeta de $-5 \mathrm{mV}$. Os animais apresentaram redução da glicemia por até 18 horas após a administração oral. 


\section{OBJETIVO GERAL}

Avaliar a viabilidade do uso de ovelhas como modelo animal para estudo dos efeitos reprodutivos gerados pela ação da insulina.

\section{1 OBJETIVOS ESPECÍFICOS}

Estudar o perfil de progesterona plasmática envolvido na reprodução de ovelhas diabéticas alloxano-induzidas, normais e expostas a elevadas doses de insulina, mediante superestimulação ovariana.

Avaliar a influência da insulina na resposta à superovulação de ovelhas diabéticas alloxano-induzidas, de ovelhas normais e daquelas expostas a elevadas doses de insulina

Avaliar as alterações histológicas geradas pala ausência ou excesso de insulina em ovários após a superestimulação para produção embrionária.

Avaliar formulações nanoestruradas de insulina para liberação sustentada e permeação de mucosa grastrintestinal. 


\section{HIPÓTESE}

A insulina interfere positivamente na produção embrionária, principalmente na quantidade e na qualidade de embriões, bem como no aumento da capacidade esteroidogênica dos corpos lúteos.

A formulação nanoestruturada deverá proporcionar teores de insulina em níevis terapêuticos por período de pelo menos 24 horas.

A formulação nanoestruturada permitirá a absorção intestinal de insulina, mantendo sua atividade biológica. 


\section{MATERIAL E MÉTODOS}

\subsection{EXPERIMENTO 1}

\subsubsection{ANIMAIS E LOCAL DO EXPERIMENTO}

O delineamento experimental foi inteiramente ao acaso, dividido em 3 tratamentos lanceados, um com nove animais em cada grupo, sendo que cada animal representa uma unidade experimental. Para tanto, foram utilizadas 27 ovelhas do tipo Santa Inês, com histórico reprodutivo conhecido, escore corporal 4 (RIBEIRO et al., 2003) e peso variando entre 38 e $49 \mathrm{Kg}$. As ovelhas foram alojadas em baias coletivas de $3 \mathrm{~m}^{2} /$ animal e divididas aleatoriamente em 3 grupos experimentais, de 9 animais: Grupo controle (GC), Grupo hiperinsulinêmico $(G H)$ e Grupo diabético (GD), sendo que cada animal representou uma unidade experimental. Os animais pertenciam à fazenda Ponte Funda e o experimento foi conduzido entre os meses de dezembro de 2006 e março de 2007, no município de Três Corações, localizado na microrregião Vale do Rio Verde, que pertence à mesorregião Sul de Minas Gerais.

Durante o período experimental, todos os animais foram mantidos em condição idêntica de manejo e dieta, constituída de suplemento mineral (Tabela 1) e silagem de milho ad libitum, fornecida duas vezes ao dia, às $7 \mathrm{~h}$ e às $16 \mathrm{~h}$.

Tabela 1: Composição percentual (\%) dos ingredientes do sal proteinado

\begin{tabular}{lc}
\hline Ingredientes & $\%$ \\
\hline $\mathrm{NaCl}$ & 15,34 \\
Mistura mineral $^{*}$ & 15,34 \\
Farelo de Algodão & 30,67 \\
Milho triturado & 26,38 \\
Uréia & 11,05 \\
Sulfato de Amônia & 1,22
\end{tabular}

* (Ingredientes/Kg de produto): Fósforo 174g; Cálcio 240g; lodo 90mg; Manganês 2000 mg; Zinco 5270 mg; Selênio 15 mg ; Cobalto 100 mg; Cobre 1250 mg; Ferro 1795 mg

O valor nutricional da silagem foi estimado em $33,34 \%$ de matéria seca, $7,27 \%$ de proteína bruta, extrato etéreo $2,62 \%, 21,75 \%$ de fibra bruta, fibra detergente ácido $28,12 \%$, fibra detergente neutro $50,73 \%$, cinzas $4,05 \%$ e nutrientes totais digestíveis $65,98 \%$. Todos os animais passaram por um período de adaptação prévia à dieta que durou 21 dias. Neste mesmo período, também foi realizado o 
cabresteamento dos animais, com intuito de não gerar estresse no momento das colheitas de sangue.

\subsubsection{PROCEDIMENTO EXPERIMENTAL}

Os animais foram superovulados e submetidos a diferentes tratamentos experimentais, para avaliação da influência dos fatores hiperinsulenemia e hipoinsulinemia na superovulação e na qualidade e quantidade dos embriões, na esteroidogênese e na citometria dos corpos lúteos pós-tratamento.

O início do protocolo (D.0) foi marcado pela inserção de um pessário vaginal, confeccionado em esponja de densidade 20 e contendo $60 \mathrm{mg}$ de Acetato de Medroxiprogesterona (INIBIDEX ${ }^{\circledR}$, Jofadel- Varginha, Brasil), seguido da superovulação com 250UI de pFSH (PLUSET ${ }^{\circledR}$, Calier-Barcelona, Espanha), do D.10 ao D.12, com aplicações intervaladas de 12 horas, em doses decrescentes (65/65, 40/40, 20/20). Na manhã do D.12, juntamente com a aplicação da quinta dose de $\mathrm{FSH}$, foi feita a remoção do pessário vaginal e, no momento da sexta dose de $\mathrm{FSH}$, foram administradas $250 \mathrm{UI}$ de gonadotrofina coriônica equina (eCG) (NOVORMON ${ }^{\circledR}$, Syntex- Buenos Aires, Argentina) e $125 \mu$ de D-cloprostenol (VETEGLAN ${ }^{\circledR}$, CalierBarcelona, Espanha). Os animais que não manifestaram estro na manhã do D.13 receberam, adicionalmente, $10 \mathrm{UI}$ de $\mathrm{pFSH}$, repetido à cada 12 horas, até a manifestação do estro.

As rufiações tiveram início 12 horas após a remoção dos pessários vaginais, sendo repetidas à cada quatro horas. Foi considerado como início do estro a aceitação voluntária da monta.

Os acasalamentos foram realizados à cada 8h após o início do estro, até o final da aceitação da monta, utilizando-se um reprodutor para cada doadora.

Para tanto, foram utilizados quatro reprodutores, com prévia avaliação andrológica, segundo os parâmetros mínimos estabelecidos pelo Colégio Brasileiro de Reprodução Animal (1998). Em cada módulo foram superovuladas 2 a 3 fêmeas, favorecendo assim o uso de um único reprodutor por doadora.

No terceiro e quarto dias após o início do estro, administrou-se $1,1 \mathrm{mg} / \mathrm{Kg}$ do antiprostaglandínico flunixin meglumine (FLUMEDIN ${ }^{\circledR}$, Jofadel- Varginha, Brasil), em intervalos de 12 horas, visando inibir a regressão prematura dos corpos lúteos. A colheita dos embriões foi efetuada por via cirúrgica no sétimo dia pós-estro. 


\subsubsection{TRATAMENTO CONTROLE}

O grupo controle foi submetido, exclusivamente, ao protocolo de superovulação e colheita dos embriões acima descrito.

\subsubsection{INDUÇÃO DA HIPERINSULINEMIA}

A condição de hiperinsulinemia, no grupo hiperinsulinêmico, foi conseguida mediante administrações diárias subcutâneas de 40 UI de insulina humana, de duração intermediária (NPH BIOHULIN ${ }^{\circledR}$, Novonordisk- Montes Claros, Brasil), divididas em duas aplicações intervaladas de 12 horas. Semelhante ao grupo diabético, as aplicações tiveram início no D.8 da sincronização, finalizando no dia que precedeu a colheita embrionária.

\subsection{INDUÇÃO DO DIABETES}

O diabetes foi induzido no grupo diabético, segundo metodologia descrita por LEENANURUKSA e MCDOWELL (1988), no oitavo dia do programa de sincronização (D.8), equivalente à 48 horas antes do início do tratamento superovulatório, pela administração intravenosa lenta (vinte segundos) de Alloxano monohidratado (A-7413, SIGMA- St. Louis, USA), na dosagem de 0,05g por kg de peso vivo, dissolvido em soro fisiológico, na proporção de 1/10 (peso/volume). Foi considerado como efetivo o tratamento indutivo de diabetes nos animais que apresentaram glicemia periférica superior à $130 \mathrm{mg} / \mathrm{dL}$, em um período de 24 a 36 horas após a aplicação do alloxano. Dois animais não responderam ao processo de indução do diabetes e, por isso foram retirados das análises estatísticas. Um terceiro animal também foi retirado das análises estatísticas por ter respondido ao tratamento superovulatório com apenas um CL. Dessa forma este tratamento foi analizado com seis repetições. 


\section{Esquema de superovulação para o grupo controle}

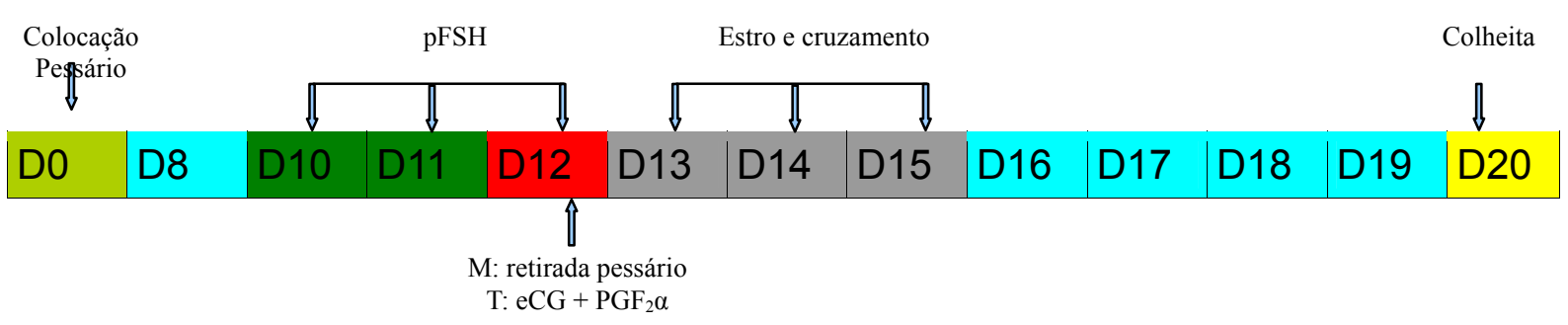

\section{Esquema de superovulação para grupo hiperinsulinêmico}

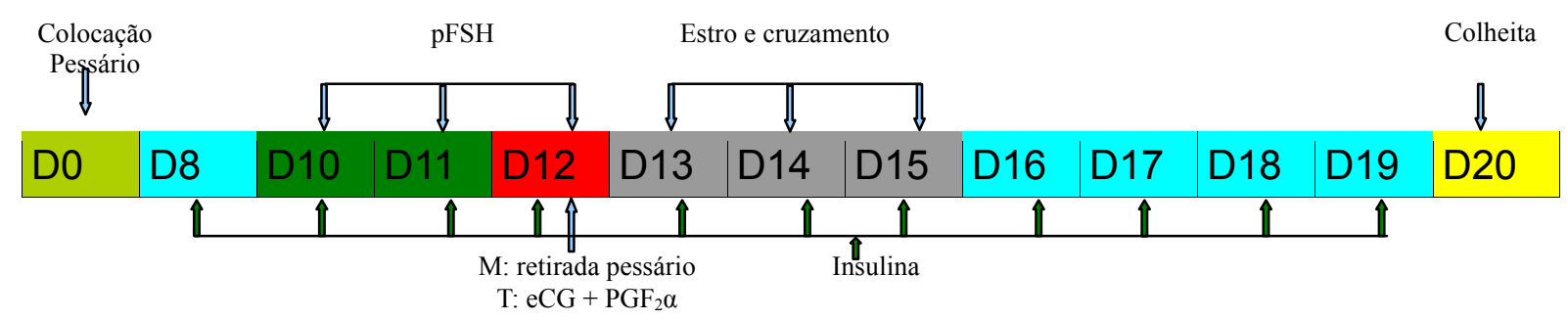

\section{Esquema de superovulação para grupo diabético}

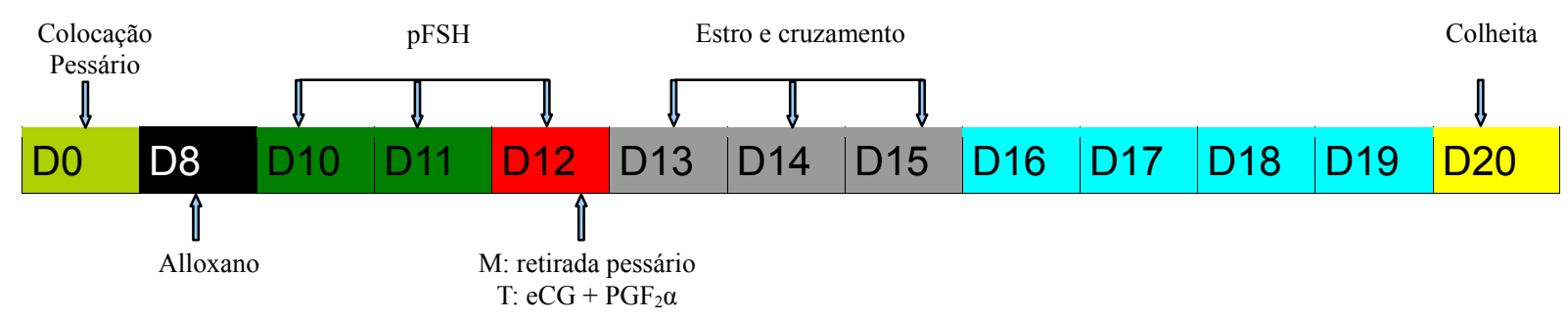

\subsubsection{COLHEITA DE SANGUE}

As colheitas de sangue tiveram início no oitavo dia do protocolo de sincronização, estendendo-se até o dia que precedeu a colheita embrionária. Estas foram realizadas às sete, treze e dezenove horas, visando dosagem plasmática de glicose, progesterona, insulina e ácido graxo não esterificado (NEFA). Tanto glicose quanto insulina foram mensuradas com as amostras de sangue colhidas às sete horas, perfazendo 12 horas pós aplicação da insulina e 15 horas após o fornecimento da dieta vespertina. Progesterona e NEFA foram dosadas, respectivamente, no plasma das amostras colhidas às treze e dezenove horas.

O sangue foi obtido por venopunção da veia jugular, com o auxílio de catéter tipo GELCRO G14 (SAFELET CATH ${ }^{\circledR}$, Nipro Medical Industries- Japão) e tubos a vácuo de $4 \mathrm{~mL}$, contendo fluoreto de sódio (LABOR- Osasco, Brasil), para inibir a glicólise. Os tubos foram centrifugados à 1222G (Centrífuga de Bancada Baby ${ }^{\circledR} 206$ 
BL, Fanem-São Paulo, Brasil), por 10 minutos, para separação do plasma e congelado à $-20^{\circ} \mathrm{C}$.

\subsubsection{COLHEITA E AVALIAÇÃO EMBRIONÁRIA}

A colheita embrionária foi realizada pela técnica cirúrgica, no sétimo dia após o início do estro. Os animais foram submetidos a um jejum alimentar de 24 horas e hídrico de $12 \mathrm{~h}$, e sedados com uma associação de cloridrato de xilazina $0,1 \mathrm{mg} / \mathrm{Kg}$ (IM) (Rompum ${ }^{\circledR}$, Bayer- São Paulo, Brasil) e cloridrato de quetamina $3,3 \mathrm{mg} / \mathrm{Kg}$ (IV) (KETAMINA, Fagra- São Paulo, Brasil), com intervalos de dez minutos, após uma administração prévia de sulfato de atropina $0,1 \mathrm{mg} / \mathrm{Kg}$ (IM) (ATROPINA, Fagra- São Paulo, Brasil). Quando necessário, uma dose adicional de 6 $\mathrm{mg} / \mathrm{Kg}$ de ketamina (IM) foi administrada para prolongar a anestesia. Os animais receberam anestesia epidural alta, com $3 \mathrm{~mL}$ de cloridrato de lidocaína a $2 \%$ (LIDOSTON ${ }^{\circledR}$, Ariston- São Paulo Brasil) e no local de incisão com $7 \mathrm{~mL}$.

Para a colheita, foi utilizada uma sonda de Foley $n^{\circ} 8$ (RuSCH 8 , Willy Rusch AG-Kermen, Alemanha) e $400 \mathrm{~mL}$ de Solução salina tamponada (DBPS) (DULBECCO MODIFICADO, Cultilab -Campinas, São Paulo), à $37^{\circ} \mathrm{C}$ por doadora, infundindo-se $200 \mathrm{~mL}$ na lavagem de cada corno uterino.

O lavado foi recolhido em filtro coletor (06.02.0010, Millipore- Billerica, USA) e, em seguida, transferido para placas de Petri (93100, TPP $^{\circledR}$ - Suiça), para posterior localização dos embriões. Durante o ato cirúrgico, também foram avaliados o número e a qualidade dos corpos lúteos (CL), classificados em graus I, II ou III. Os $\mathrm{CL}$ foram agrupados por animal e aplicado o índice de qualidade de $\mathrm{CL}$ (IQCL), adaptado de Sales e colaboradores (2008) e descrito na tabela 2. O uso desse índice se deve ao fato de que os CL não podem ser utilizados como unidades experimentais, uma vez que quem sofreu o tratamento foi a ovelha e não $\circ \mathrm{CL}$ individualizado.

O IQCL é calculado pela fórmula IQCL $=(\mathrm{CL}$ grau I * $1+\mathrm{CL}$ grau II * $2+\mathrm{CL}$ grau III * 3$) / \mathrm{n}^{\circ}$ de $C L$ total. Por exemplo, uma ovelha que apresentou $3 \mathrm{CL}$ grau I e 2 $\mathrm{CL}$ grau III apresentará IQCL $=\left(3^{*} 1+2 * 3\right) / 5=1,8$. Assim, quanto mais próximo de 1 for o IQCL, melhor será a qualidade dos CL.

Uma vez identificados os embriões, em esteromicroscópio, em aumento de 20 vezes, estes foram transferidos para uma placa contendo meio de manutenção (Holding, Embriocare ${ }^{\circledR}$ Cultilab -Campinas, São Paulo), para classificação 
embrionária, sob aumento de 60 vezes, segundo normas da Sociedade Internacional de Transferência de Embriões (1999) e transferidos quando houve disponibilidade de receptoras ou criopreservados em etileno glicol 1,5M (Freeze, Embriocare ${ }^{\circledR}$ Cultilab Campinas, São Paulo).

Tabela 2: Critérios usados na classificação morfológica dos Corpos Lúteos.

\begin{tabular}{ll}
\hline Categoria & \multicolumn{1}{c}{ Descrição } \\
\hline Grau 1 & CL maior que $8 \mathrm{~mm}$, protruído e de coloração vermelho intensa \\
Grau 2 & CL com tamanho variando entre 5 e $8 \mathrm{~mm}$, coloração vermelho claro à intenso. \\
Grau 3 & CL menor que $5 \mathrm{~mm}$, de coloração pálida, com tonalidade tendendo de \\
& vermelho-amarelada à amarelada. \\
\hline
\end{tabular}

Pelos mesmos motivos já observados para os $C L$, os embriões foram comparados pelo índice de qualidade embrionária (IQE), que foi obtido pela fórmula, IQE $=\left(n^{\circ}\right.$ embrião I * $1+n^{\circ}$ embrião II * $2+n^{\circ}$ embrião III * $3+n^{\circ}$ degenerados $4+n^{\circ}$ de óvulos $\tilde{n}$ fertilizados) $/ \mathrm{n}^{\circ}$ de estruturas totais (SALES et al, 2008).

Após a cirurgia, os animais receberam $1,1 \mathrm{mg} / \mathrm{Kg}$ de flunixin meglumine (FLUMEDIN $^{\circledR}$, Jofadel- Varginha, Brasil) e 20.000 UI/Kg de penicilina (AGRODEL ${ }^{\circledR}$, Jofadel- Varginha, Brasil), em intervalos de 12 horas, durante cinco dias, para posterior reincorporação ao rebanho.

\subsubsection{AVALIAÇÕES DE HORMÔNIOS, GLICOSE E NEFA}

As concentrações plasmáticas de progesterona foram determinadas por radioimunoensaio, de anticorpo em fase sólida (Coat-a-Count ${ }^{\circledR}$, DPC - Los Angeles, USA ) e fazendo uso do $1^{125}$ como elemento traçador. Os testes foram realizados em simplicata, com $100 \mu \mathrm{L}$ de amostra provenientes do soro e seguindo-se as recomendações do fabricante. A sensibilidade do teste foi de $0,001 \mathrm{ng} / \mathrm{mL}$, e o coeficiente de variação intraensaio foi de $2,54 \%$ para amostra de baixo teor e de $1,02 \%$ para a de alto teor de progesterona.

A insulina foi quantificada por radioimunoensaio de anticorpo em fase sólida, utilizando kit comercial (INS-Irma, Biosource - Nivelles, Belgica) e fazendo uso do $1^{125}$ como elemento traçador. Os testes foram realizados em duplicata, com $50 \mu \mathrm{L}$ de amostra provenientes do soro e seguindo-se as recomendações do fabricante. Todos os ensaios foram realizados no Laboratório de Reprodução Animal da Embrapa Gado de Leite (Coronel Pacheco/MG), com o auxílio de um contador gama (Gammatec model 600, The Nucleus Inc.- Oak Ridge, USA.). A sensibilidade do 
ensaio foi de $0,1 \mu \mathrm{Ul} / \mathrm{mL}$ e os coeficientes de variação inter e intraensaio foram inferiores à $8 \%$.

A determinação do ácido graxo não esterificado (NEFA) foi realizada em duplicata, pelo método enzímico-colorimétrico, com auxílio de kit comercial (FA 115 NEFA, Randox - Antrim, United Kingdom). Os testes foram conduzidos em microplacas de 96 poços (Microplate 176-6020, Bio-Rad - Hercules, USA), seguindo-se as recomendações do fabricante e as leituras de absorbância feitas no comprimento de onda de $595 \mathrm{~nm}$, em um leitor de ELISA (Microplate Reader 3550, Bio-Rad - Hercules, USA). Após as leituras, os valores foram convertidos em concentração ( $\mu \mathrm{mol} / \mathrm{L})$ utilizando-se a curva padrão determinada. Os ensaios para quantificação da glicose seguiram os mesmos procedimentos, porém foram conduzidos com kit específico (GL3815 GLUC-PAP, Randox - Antrim, United Kingdom) e as leituras foram realizadas no comprimento de onda de $490 \mathrm{~nm}$.

\subsubsection{COLHEITA DE AMOSTRAS PARA AVALIAÇÃO HISTOPATOLÓGICA}

Treze animais sacrificados por eutanásia, com a utilização de anestesia geral, por associação de cloridrato de xilazina $0,2 \mathrm{mg} / \mathrm{Kg}$ (Rompum ${ }^{\circledR}$, Bayer- São Paulo, Brasil) e cloridrato de quetamina $15 \mathrm{mg} / \mathrm{Kg}$ (IM) (KETAMINA, Fagra- São Paulo, Brasil), foram destinados para colheita de material histológico,. Uma vez inconsciente, o sacrifício foi realizado com uma dose de $10 \mathrm{~mL}$ de cloreto de potássio à 10\% (I.V.). Dos animais sacrificados, seis pertenciam ao grupo diabético, quatro ao grupo hiperinsulinêmico e três ao grupo controle.

Amostras de ovários, contendo $\mathrm{CL}$ e fígados foram acondicionadas em formol salina tamponado à $10 \%$, fragmentados e posteriormente incluídas em parafina. Após inclusão em parafina, foram cortados, com espessura de $4 \mu \mathrm{m}$ e corados com hematoxilina-eosina. Para a confecção dos cortes histológicos dos CL, seguiu-se metodologia descrita por Neves e Marques (2002), na qual foram reduzidos a cortes finos e retirados fragmentos de três pontos significativos para confecção das lâminas (figura 3). Uma vez inclusos em parafina, foram realizados cortes de $4 \mu \mathrm{m}$ e, posteriormente, corados por hematoxilina-eosina. 


\section{प11}

Figura 3: Esquema de pontos de amostragem para histologia de CL, adaptado de Neves e Marques (2002).

As análises de citometria foram realizadas seguindo-se metodologia adaptada de Neves e Marques (2006) e Neves e Marques (2002), na qual foram geradas imagens de 35 campos aleatórios, por $\mathrm{CL}$, com o auxílio de uma máquina digital, adaptada para microscopia óptica (Cyber-shot DSC-W110, Sony - China), previamente acoplada em um microscópio óptico, em objetiva de 40x (Axioplan I, Zeiss - Alemanha). As imagens foram processadas com o auxílio do software livre Image J (Image J, Image Processing and Analysis in Java - Bethesda, USA), fixando-se os parâmetros: distance in pixel $=7050$; known distance $=1 \mu \mathrm{m}$; Feres't diameter and area. Nestas configurações, foram avaliadas todas as células células luteínicas maiores (LLC: iniciais de Large Luteal Cell) e células luteínicas menores (SLC: iniciais de Small Luteal Cell), que apresentaram núcleo visível, fibroblastos e tecido conjuntivo, capilares e pericitos e células com sinais de apoptose. A determinação da área de tecido luteínico foi obtida pela subtração do somatório das áreas fibroblastos e tecido conjuntivo, capilares e pericitos e células com sinais de apoptose da área total avaliada.

\subsubsection{ANÁLISE ESTATÍSTICA}

Os dados foram interpretados por análise de variância com o auxílio do pacote estatístico SAS. Para as análises de medidas repetidas no tempo (insulina, progesterona, glicose e NEFA) foi utilizado o procedimento MIXED. Para as demais análises, que apresentavam distribuição normal (transformadas ou não), foi utilizado o procedimento GLM, enquanto que, para analisar amostras que seguiram uma distribuição de Poison, utilizou-se o procedimento GLIMMIX. Quando detectada diferença significativa, foi aplicado o teste Tukey para separação das médias.

Os coeficientes de regressão e os níveis de significância foram determinados pelo procedimento Corr do SAS, sendo utilizados para os dados paramétricos a correlação de Pearson e para os não paramétricos, a correlação de 
Spearman.

\subsubsection{MODELO ESTATÍSTICO}

$$
\begin{array}{r}
Y_{i j}=\mu+t_{i}+E_{(i) j} \quad i=1,2, \ldots \ldots, t \\
j=1,2, \ldots \ldots, r_{i}
\end{array}
$$

Onde,

$Y_{i j}=$ valor da parcela que recebeu o tratamento i na repetição j;

$\mu=$ média geral do experimento;

$t_{i}=$ efeito do tratamento $i$; $\left(0, \delta^{2}\right)$

$E_{(i) j}=$ erro da parcela que recebeu o tratamento i na repetição j e $E_{(i) j} \sim N$

\subsection{EXPERIMENTO 2}

\subsubsection{NANOENCAPSULAMENTO DA INSULINA E CARACTERIZAÇÃO DO SISTEMA}

\subsubsection{CONFECÇÃO DAS NANOPARTÍCULAS}

Utilizou-se uma quitosana de baixo peso molecular (448869, Aldrich Wisconsin, USA), com $91,8 \%$ de desacetilação e 32 CPS de viscosidade (C=1\% em $1 \%$ de ácido acético), segundo o certificado de análise do lote 04809DH; ácido acético (A6283, SIGMA- St. Louis, USA ); tripolifosfato de sódio (TPP) (28874, Dinâmica- Diadema, Brasil); insulina cristalina humana (Novonordisk- Montes Claros, Brasil), 26,1 UI/mg e 0,4\% de zinco.

O processo de confecção das nanopartículas foi realizado por geleificação ionotrópica, após adaptações da técnica previamente descrita por Calvo e colaboradores (1997).

Para tanto, foi preparada uma solução de quitosana, 2,06 mg/mL (solução 1), solubilizada em ácido acético $0,1 \%$ em água Milli-Q (Milli-Q Biocell Siytem, Millipore - Billencia, USA), e pH ajustado para 5,5; solução (solução 2) de TPP $1 \mathrm{mg} / \mathrm{mL}$, em água Milli-Q e pH ajustado para 9. 
Uma vez confeccionadas as soluções, adicionaram-se $0,515 \mathrm{mg}$ de insulina à solução de quitosana. Após a adição do hormônio, todas as soluções foram filtradas, em filtro de metil-acetato celulose regenerada, 0,22 $\mu \mathrm{m}$ (18407, Sartorius Gottingen, Alemanha), em fluxo laminar (BioSAFE, Veco - Campinas, Brasil).

A produção das nanopartículas (figura 4) foi conseguida pelo suave gotejamento da solução 1 sobre a solução 2, sob agitação de 600 rpm (MA085, Marconi-Piracicaba, Brasil), auxiliado por uma bomba peristáltica (2115, LKBBromma, Suécia), com fluxo de $140 \mathrm{~mL} /$ hora e um mangote de silicone, com diâmetro interno de $3 \mathrm{~mm}$, previamente conectado a uma ponteira de $200 \mu \mathrm{L}$ para micropipetas (256019, Gilson-Villiers, França). A solução 2 foi mantida em banho de gelo durante seu processamento.

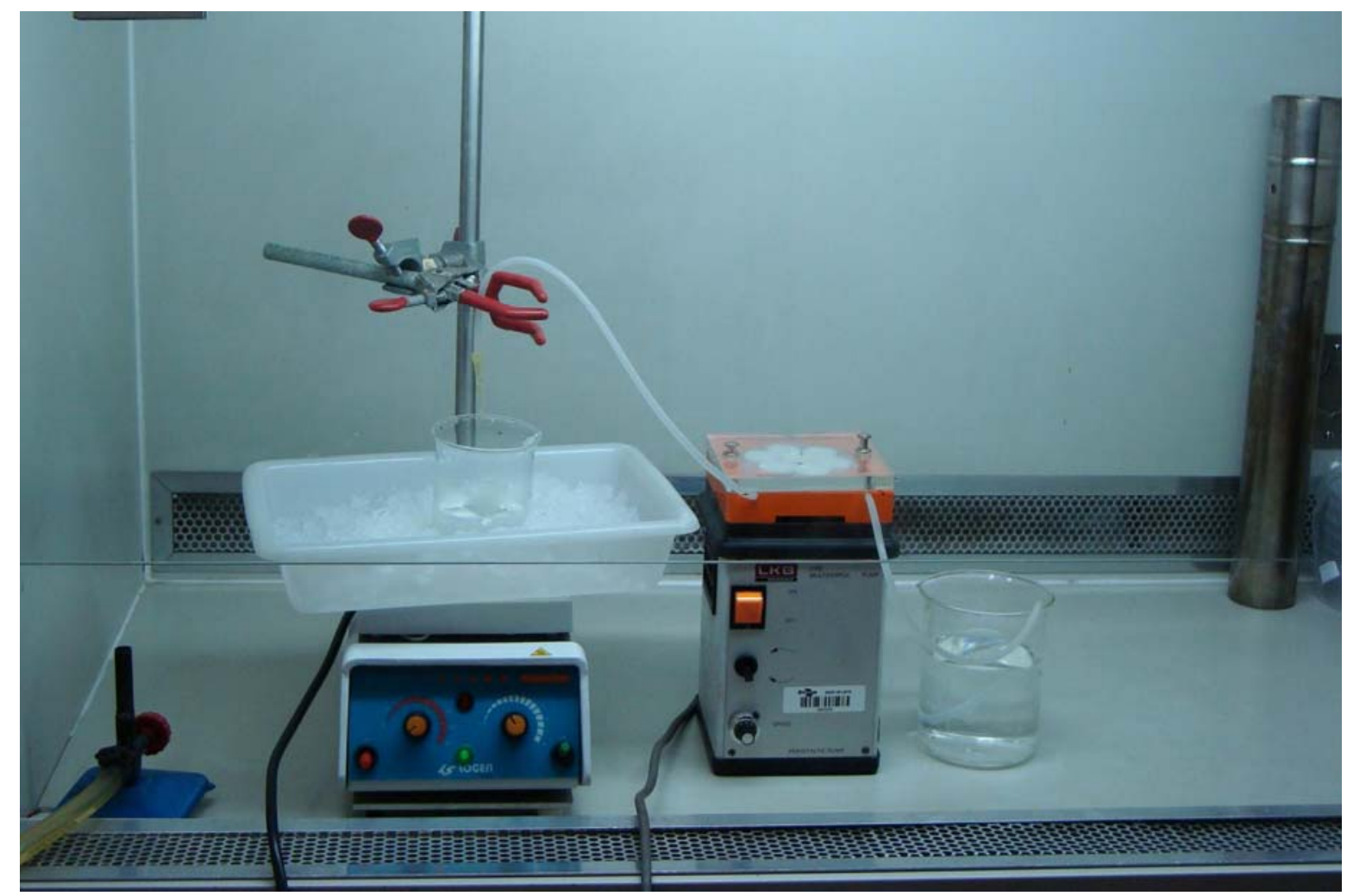

Figura 4: Sistema para preparo de nanopartículas por geleificação ionotrópica.

As nanopartículas em solução foram centrifugadas à $40.355 \mathrm{G}$, à $4^{\circ} \mathrm{C}$, por 40 minutos, em uma centrífuga refrigerada (RC5B Superspeed, Sorvall,- Chicago, USA). Após a remoção do sobrenadante, no qual $1 \mathrm{~mL}$ foi separado para quantificação, obteve-se um agregado de nanopartícilas na forma de gel. Tal procedimento se repetiu mais uma vez com a adição de água milli-Q para a completa remoção da insulina livre.

O agregado de nanopartículas foi então congelado em nitrogênio líquido e, 
posteriormente, liofilizado por 48 horas (Freeze dryer 18, Labconco - Kansas, USA).

A determinação da eficiência de encapsulamento das partículas foi feita com o auxílio do valor total de insulina adicionada ao meio de formação de nanopartículas e insulina livre, presente na solução aquosa sobrenadante, como observado na equação 1.

Equação 1- Eficiência de encapsulamento = $(\operatorname{Ins} A-\operatorname{lns} L) / \operatorname{lns} A$ * 100

onde: Ins A = insulina adicionada ao meio de formação de nanopartículas Ins $L=$ insulina livre no sobrenadante da formulação

A insulina foi quantificada tanto no sobrenadante, quanto na solução 1 , por cromatografia líquida de alto desempenho em fase reversa (HPLC-rp), pelo método descrito e, previamente validado, perante as normas do International Conference on Harmonization Guideline, de 1996, por Sarmento e colaboradores (2006).

As mensurações foram realizadas em um sistema HPLC-rt Shimadzu (Shimadzu-Kyoto, Japão), composto por um detector UV (SPD-A10), bomba (LC10AT) e sistema controlador (SCL-A10) e com o auxílio de uma coluna C18rp $5 \mu \mathrm{m} \times 3,9 \times 300 \mathrm{~mm}$ (Waters, Milford, USA). A fase móvel foi constituída de $40 \%$ de acetonitrila (412374, Carlos Erba-Duque de Caxias, Brasil ) e 60\% de ácido trifluoracético 0,1\% (v/v) (T0274, SIGMA- St. Louis, USA) . O eluente foi bombeado, com um fluxo de $1,5 \mathrm{~mL} / \mathrm{min}$ e pressão de $143 \mathrm{~kg} / \mathrm{F}$. O tempo de retenção da insulina foi de 2,08 min e detectada em um comprimento de onda de $210 \mathrm{~nm}$.

\subsubsection{ANÁLISE DE ESPALHAMENTO DE LUZ DINÂMICO}

O índice de polidispersividade (IPD), a distribuição de tamanho das partículas e o potencial Zeta foram determinados por Espalhamento de luz dinâmico (DLS), com o auxílio do equipamento Nanosetasizer (Malvern Instruments- Malvern, England), no Laboratório de Nanotecnologia da Embrapa Instrumentação Agropecuária, São Carlos.

As análises foram realizadas em duplicata, para cada amostra, com suspensões de $1,5 \mathrm{~mL}$ de nanopartículas, acondicionadas em cubeta apropriada (DTS1060, Malvern Instruments- Malvern, England). A temperatura de análise foi de $25^{\circ} \mathrm{C}$ e o equipamento foi calibrado para realizar dez mensurações por análise. 


\subsubsection{ANÁLISES DE MICROSCOPIA ELETRÔNICA DE VARREDURA DE ALTA RESOLUÇÃO (MEV)}

As nanopartículas liofilizadas foram depositadas em uma fita adesiva de carbono dupla face (Eletron Micrescopy Sciences - Washington, USA), imobilizada sobre um suporte metálico, de dois centímetros de diâmetro, próprio para MEV. Em seguida, cada amostra sofreu um processo de metalização à vácuo, com uma fina camada de ouro (SDC 50, Baltec AG - Liechtenstein, Suiça), com distância de trabalho de 4 centímetros, pressão de 0,01 mbar e tempo de cobertura de 70 segundos.

Todas as amostras tiveram pequenos segmentos de sua superfície micrografadas, em um microscópio eletrônico de varredura de alta resolução (FEG XL30, Philips Electronic Instruments - Mahwah, USA), com aumento de 70.000 vezes e potência de $5 \mathrm{kV}$, no Departamento de Engenharia de Materiais da Universidade Federal de São Carlos.

\subsubsection{ESPECTROSCOPIA DE INFRA VERMELHO}

Foram gerados os espectros da insulina, quitosana, tripolifosfato de sódio (TPP) e das nanopartículas com e sem insulina. Para o espectro de Infravermelho, foi utilizado um espectrômetro FTIR MB 102, ABB Bomem-Zurique, Suiça), com espectros coletados na região de número de ondas variando de 4000 a $400 \mathrm{~cm}-1$, em suporte de $\mathrm{KBr}$, com média 64 scans e resolução espectral de $4 \mathrm{~cm}-1$. A análise espectral foi realizada no laboratório de Espectroscopia Molecular do Departamento de Química da Universidade Federal de Juiz de Fora.

\subsubsection{DETERMINAÇÃO DO PADRÃO DE LIBERAÇÃO}

\subsubsection{DETERMINAÇÃO DO PADRÃO DE LIBERAÇÃO IN VITRO}

O padrão de liberação in vitro da insulina encapsulada foi determinado em meio PBS pH 7,4 (USP XXIV), sob agitação constante de 150 rpm e temperatura de $38^{\circ} \mathrm{C}$. Para tanto, foi adaptado uma agitador magnético (MA085, MarconiPiracicaba, Brasil), no interior de shaker, com controle de temperatura (Incubator Shaker 25, New Brunswich- Edison, USA), porém com a bandeja agitadora desligada.

O equivalente à $4 \mathrm{mg}$ de insulina encapsulada, em nanopartículas 
liofilizadas, foi introduzido no interior de uma membrana de diálise (D9277 SIGMASt. Louis, USA) e, posteriormente acomodada em um becker, contendo $50 \mathrm{~mL}$ de PBS (Figura 5). Foram coletadas amostras de $1 \mathrm{~mL}$, para quantificação por HPLC-rp, nos tempos de incubação: $1 ; 2 ; 3 ; 4 ; 5 ; 6$ e 24 horas. Para manutenção da condição Sink, volume igual de PBS puro foi adicionado ao sistema, garantindo assim, uma situação de diluição infinita no meio de liberação.

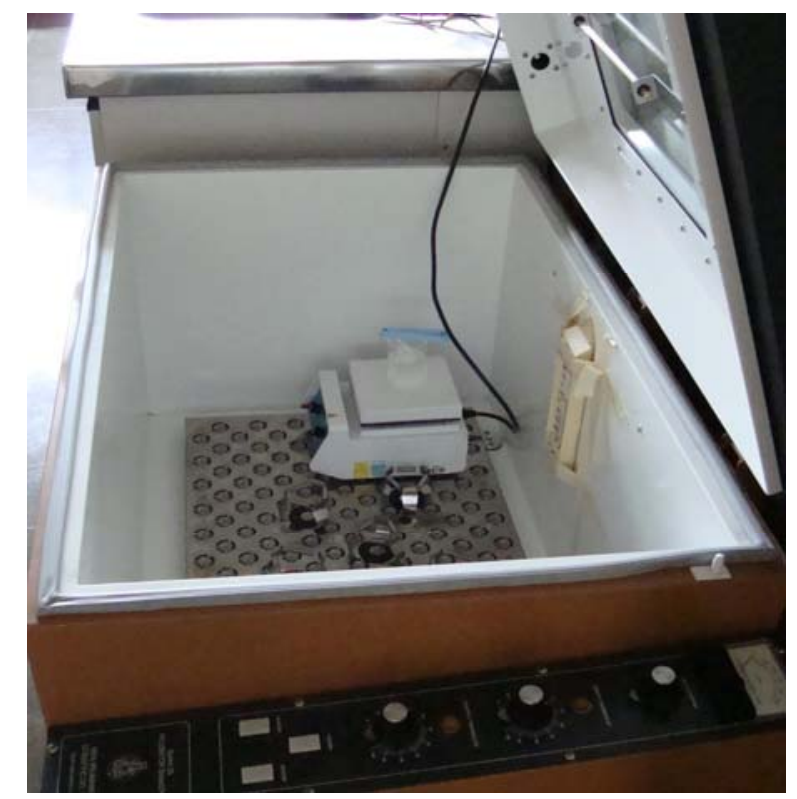

Figura 5: Sistema para avaliação do padrão de liberação in vitro de nanopartículas.

\subsubsection{FORMULAÇÕES PARA AVALIAÇÃO DA LIBERAÇÃO IN VIVO}

Todas as formulações foram preparadas a partir de nanopartículas produzidas e liofilizadas em condição estéril. Para tanto, os agregados de nanopartículas foram macerados em um fluxo laminar (BioSAFE, Veco - Campinas, Brasil) e aliquotadas em seringas de $10 \mathrm{~mL}$ (Injex- Ourinhos, Brasil), de acordo com a demanda de cada animal e tratamento.

Quando administrada pela via subcutânea, tanto a insulina pura quanto as nanopartículas foram ressuspendidas em $8 \mathrm{~mL}$ de soro fisiológico (Equiplex-Goiânia, Brasil), 25 minutos antes da aplicação. Para administração oral, quando administradas no veículo aquoso, o procedimento foi o mesmo, alterando apenas a via de aplicação.

Pela via oral, em um dos tratamentos, as nanopartículas foram incorporadas em uma matriz lipídica (Saúde ${ }^{\circledR}$, Siol Alimentos - Barueri, Brasil), composta por 
gordura vegetal $(25 \%$ gordura saturada, $37 \%$ gordura trans e ponto de fusão de $27^{\circ} \mathrm{C}$ ). A incorporação consistiu do aquecimento de $8 \mathrm{~mL}$ de matriz lipídica, até o ponto de fusão $\left(28^{\circ} \mathrm{C}\right)$, adição de nanopartículas, homogeneização manual, com o auxílio de uma espátula fina e posterior resfriamento.

\subsubsection{ANIMAIS E LOCAL DO ENSAIO DE LIBERAÇÃO IN VIVO}

Foram utilizados 4 cordeiros do tipo Santa Inês, pesando $24 \pm 2,5 \mathrm{Kg}$ e possuindo 4 meses de idade e dois meses pós desmame. Os cordeiros foram alojados em uma baia coletiva de $6 \mathrm{~m}^{2}$. Os quatro animais passaram por todos os 7 tratamentos, respeitando-se um intervalo de 24 horas entre o término de um tratamento e o início de outro, para evitar efeito residual dos tratamentos. Cada animal representou uma unidade experimental.

Os animais pertenciam à Embrapa Gado de Leite e o experimento foi conduzido nos meses de agosto e setembro de 2009, no município de Coronel Pacheco, localizado na microrregião de Juiz de Fora, que pertence à mesorregião Zona da Mata de Minas Gerais.

Durante o período experimental, todos os animais foram mantidos em condição idêntica de manejo e dieta, constituída de suplemento mineral (Tab.1) e silagem de milho ad libitum, fornecida apenas às $8 \mathrm{~h}$. O valor nutricional da silagem foi estimado em $30,87 \%$ de matéria seca, 6,62\% de proteína bruta, extrato etéreo $1,44 \%, 21,75 \%$ de fibra bruta, FDA 30,09\%, FDN 48,18\%, cinzas 4,12\% e NDT $62,51 \%$. Todos os animais passaram por um período de adaptação prévia à dieta que durou 2l dias. Neste mesmo período, também foi realizado o cabresteamento dos animais, com intuito de não gerar estresse, no momento das colheitas de sangue.

Quarenta e oito horas antes de iniciar o ensaio de liberação in vivo, todos os animais passaram pelo processo de indução do diabetes, conforme descrito no experimento 1.

As colheitas de sangue foram realizadas nos tempos $0,1,2,4,6,10,12,14$ e 24 horas e seguiram os procedimentos previamente descritos no experimento 1.

Os tratamentos foram constituídos por:

Trat.1: $8 \mathrm{~mL}$ de soro fisiológico subcutâneo;

Trat.2: Nanopartículas sem insulina, em 8 mL de soro fisiológico subcutâneo; 
Trat.3: 2,5 UI/kG de insulina, em $8 \mathrm{~mL}$ de soro fisiológico subcutâneo;

Trat.4: 2,5 Ul/kG de insulina encapsulada, em $8 \mathrm{~mL}$ de soro fisiológico subcutâneo;

Trat.5: $50 \mathrm{Ul} / \mathrm{kG}$ de insulina, em $8 \mathrm{~mL}$ de soro fisiológico oral;

Trat.6: $50 \mathrm{UI} / \mathrm{kG}$ de insulina encapsulada, em $8 \mathrm{~mL}$ de soro fisiológico oral;

Trat.7: $50 \mathrm{UI} / \mathrm{kG}$ de insulina encapsulada, incorporada em $8 \mathrm{~mL}$ de matriz lipídica oral.

A linha de base para glicemia foi determinada, com a média dos resultados de duas colheitas, com intervalos de meia hora antes de se iniciarem os tratamentos pela manhã, adaptado de Lin e colaboradores (2007). .

O doseamento da glicose plasmática foi determinado pelo procedimento previamente descrito no experimento 1 , enquanto a insulina foi determinada em duplicata, utilizando-se kit comercial de imunoensaio de eletroquimioluminescência (COBAS Insulin, Roche - Suiça) e leitura em um equipamento Elecsys (2010, Roche - Suiça). A sensibilidade do ensaio foi de $0,2 \mu \mathrm{Ul} / \mathrm{mL}$ e os coeficientes de variação inter e intraensaio foram, respectivamente, $2,8 \%$ e 2,1\%. As análises foram realizadas nas dependências do Laboratório Dom Bosco, Rio de Janeiro.

Pelo fato dos animais não serem contemporâneos, optou-se por fazer uma análise descritiva sem comparação de médias. 


\section{RESULTADOS}

\subsection{EXPERIMENTO 1}

\subsubsection{OBSERVAÇÕES GERAIS}

Durante o processo de indução do diabetes, dois animais não responderam ao tratamento, apresentando glicemia periférica suavemente aumentada, respectivamente de 85 e $100 \mathrm{mg} / \mathrm{dL}$ e, por isso foram retirados do experimento. Neste mesmo grupo, um terceiro animal não respondeu ao processo superovulatório e, por isso, também foi retirado do experimento.

Entre o quinto e o sexto dias pós indução do diabetes, todos os animais desse grupo apresentaram redução do escore corporal e sinais clínicos de cetose, como letargia, perda de apetite e odor cetônico no ar expirado.

No grupo suplementado com insulina, quatro animais apresentaram queda do escore corporal e, pelo menos por duas vezes, manifestaram sinais clínicos de hipoglicemia ao longo do tratamento, externando letargia e baixa resposta aos estímulos externos. Apesar de não mensurada, ocorreu visível redução no consumo de forragem quando comparado ao grupo controle. Os animais frequentemente se encontravam com o flanco esquerdo deprimido e perderam peso, fato mais frequente nas ovelhas que manifestaram sintomas de hipoglicemia.

\subsubsection{CONCENTRAÇÃO PLASMÁTICA DE INSULINA E GLICOSE}

Houve interação entre tempo e tratamento, para os teores de insulina (fig.6). Entretanto, em nenhum momento, pode-se verificar uma interação de ordem, apenas de grandeza. Nas amostras colhidas no D-2, D-1 e D.0 os teores de insulina nos animais diabéticos foram significativamente inferiores ao dos animais controle e hiperrinsulinêmicos, que não diferiram entre si. A partir do D. 1 até o D.4 os teores de insulina do grupo controle, ocuparam uma posição intermediária não diferindo, significativamente, dos teores encontrados nos animais do grupo hiperinsulinêmico e diabético, que diferiram significativamente entre si. Por fim as diferenças não foram significativas no D.5.

Considerando-se, no qual, o efeito de tratamento, pode-se verificar que os três tratamentos diferiram entre si, em que o grupo hiperinsulinêmico apresentou, em 
média, maior concentração plasmática de insulina $(20,05 \pm 0,9 \mu \mathrm{UI} / \mathrm{mL})$, seguido do grupo controle $(14,52 \pm 0,4 \mu \mathrm{Ul} / \mathrm{mL})$ e grupo diabético $(10,18 \pm 0,5 \mu \mathrm{Ul} / \mathrm{mL}),(p<0,01)$.

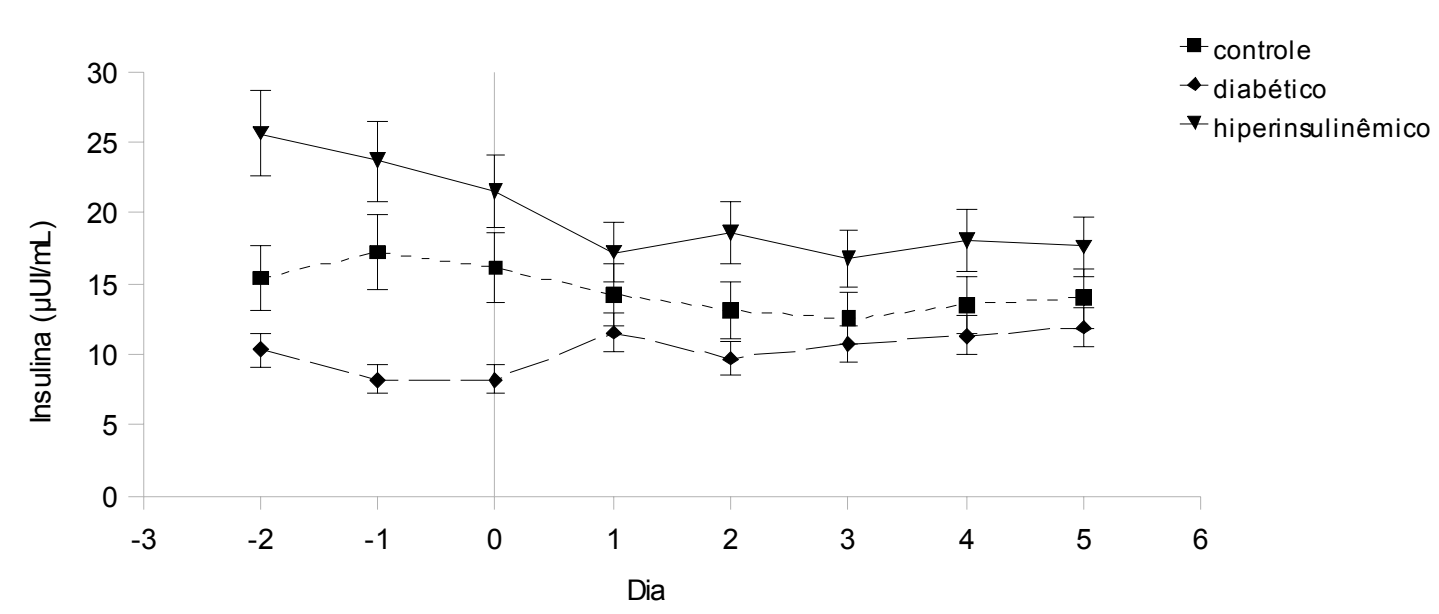

Figura 6: Concentração plasmática de insulina em ovelhas diabéticas, hiperinsulinêmicas e controle superovuladas.

Nas análises de correlação, a insulina foi correlacionada negativamente com o IQCL $\left(R^{2}=0,47, P<0,05\right)$ e com IQE $\left(R^{2}=0,39, P<0,05\right)$.

Não houve interação entre tempo e tratamento. Contudo, houve diferença $(\mathrm{P}<0,01)$ entre os tratamentos, para a variável glicemia, na qual o grupo diabético $(241,2 \pm 9,2 \mathrm{mg} / \mathrm{dL})$ apresentou valor mais elevado que a do grupo controle $(83,1 \pm 2,1$ $\mathrm{mg} / \mathrm{dL})$, que por sua vez foi maior que a do grupo hiperinsulinêmico $(53,9 \pm 2,7$ $\mathrm{mg} / \mathrm{dL}$ ). (figura 7).

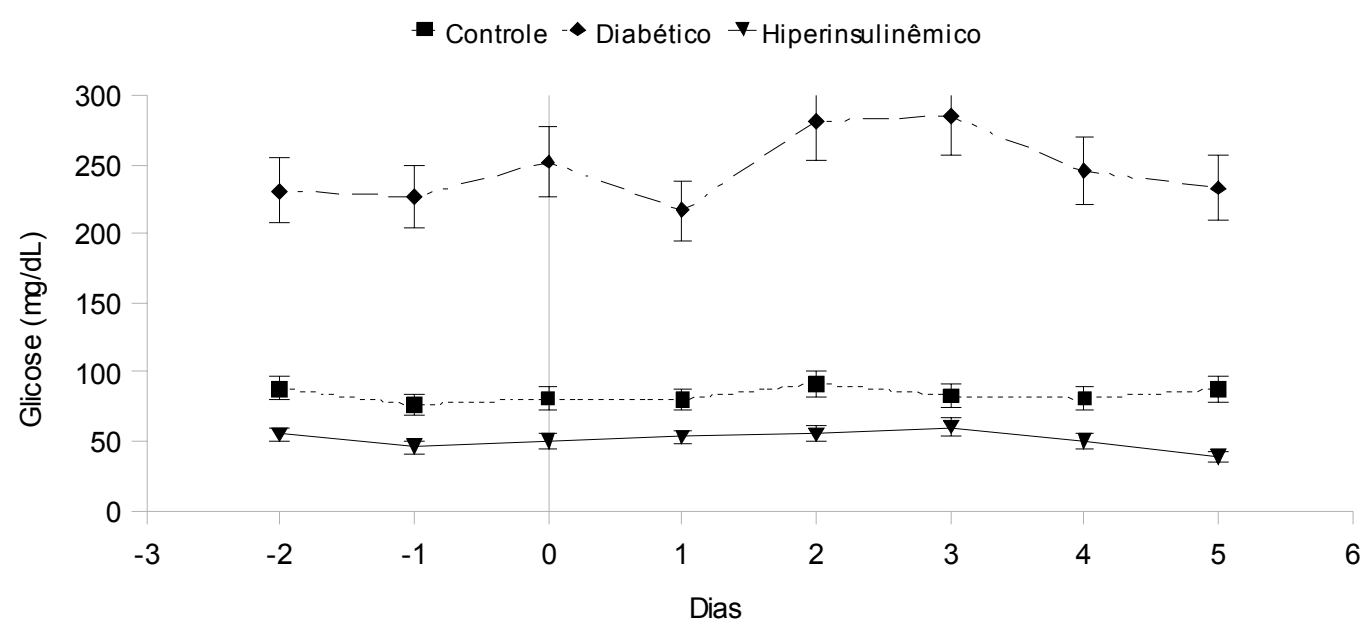

Figura 7: Concentração plasmática de glicose em ovelhas diabéticas, hiperinsulinêmicas e controle superovuladas $(\mathrm{P}<0,01)$. 


\subsection{3 ÁCIDO GRAXO NÃO ESTERIFICADO (NEFA)}

Imediatamente antes de induzir o diabetes e a condição de hiperinsulinemia (D-6) o NEFA foi mensurado nos animais destinados aos três tratamentos, não diferindo entre si. Após o final do estro (D.0), os animais diabéticos apresentaram maior concentração de NEFA plasmático $(0,41 \pm 0,11 \mathrm{mmol} / \mathrm{L})$ do que os animais controle $(0,04 \pm 0,01 \mathrm{mmol} / \mathrm{L})$ e hiperinsulinêmicos $(0,02 \pm 0,002 \mathrm{mmol} / \mathrm{L}, \quad p<0,001)$ (tabela 3)

Tabela 3: Média do ácido graxo não esterificado plasmático em mmol/L e seu respectivo erro padrão em ovelhas controle, diabéticas e hiperinsulinêmicas superovuladas

\begin{tabular}{lcccc}
\hline Dia & $\begin{array}{c}\text { Controle } \\
(\mathrm{mmol} / \mathrm{L})\end{array}$ & $\begin{array}{c}\text { Diabético } \\
(\mathrm{mmol} / \mathrm{L})\end{array}$ & $\begin{array}{c}\text { Hiperinsulinêmico } \\
(\mathrm{mmol} / \mathrm{L})\end{array}$ & $\mathrm{P}$ \\
\hline Início do Tratamento & $0.039 \pm 0.011(9)$ & $0.025 \pm 0.008(6)$ & $0.025 \pm 0.015(9)$ & 0,67 \\
Final do Estro (D.0) & $0.046 \pm 0.013^{\mathrm{B}}(9)$ & $0.438 \pm 0.117^{\mathrm{A}}(6)$ & $0.036 \pm 0.028^{\mathrm{B}}(9)$ & 0,001 \\
D.2 & $0.052 \pm 0.023^{\mathrm{B}}(9)$ & $0.353 \pm 0.093^{\mathrm{A}}(6)$ & $0.006 \pm 0.002^{\mathrm{B}}(9)$ & 0,001 \\
D.4 & $0.025 \pm 0.008^{\mathrm{B}}(9)$ & $0.405 \pm 0.100^{\mathrm{A}}(6)$ & $0.010 \pm 0.004^{\mathrm{B}}(9)$ & 0,001 \\
\hline
\end{tabular}

As concentrações de NEFA observadas entre os tratamentos no D.0, se mantiveram constantes no D.2 e no D.4.

No D.4, as concentrações plasmáticas de NEFA foram correlacionadas negativamente com as concentrações de insulina $\left(R^{2}=-0,42, \quad P<0,05\right)$, de progesterona $\left(R^{2}=-0,44, P<0,05\right)$ e com o número de $C L\left(R^{2}=-0,6, P<0,01\right)$ e positivamente correlacionada com o IQCL $\left(R^{2}=0,46, P<0,01\right)$ e IQE $\left(R^{2}=0,65\right.$, $P<0,01)$.

\subsubsection{DURAÇÃO DO ESTRO}

Não foi observada diferença estatística no intervalo entre a remoção do pessário vaginal e início do estro entre os grupos experimentais (tabela 4).

Tabela 4: Intervalo médio de tempo entre a remoção do pessário vaginal e o início do estro (horas) e a duração média do estro de ovelhas, controle, diabéticas e hiperinsulinêmicas e seu respectivo erro padrão.

\begin{tabular}{|c|c|c|c|c|}
\hline & $\begin{array}{l}\text { Controle } \\
\text { (horas) }\end{array}$ & $\begin{array}{l}\text { Diabético } \\
\text { (horas) }\end{array}$ & $\begin{array}{l}\text { hiperinsulinêmico } \\
\text { (horas) }\end{array}$ & $P$ \\
\hline $\begin{array}{ll}\text { Intervalo } & \text { retirada } \\
\text { pessário estro } & \end{array}$ & $28.7 \pm 1.7(9)$ & $36 \pm 4.7(6)$ & $30.9 \pm 4.2(9)$ & 0,35 \\
\hline Duração do estro & $48.7 \pm 3.8^{A}(9)$ & $26.4 \pm 1^{\mathrm{B}}(6)$ & $49.3 \pm 4.2^{\mathrm{A}}(9)$ & 0,003 \\
\hline
\end{tabular}

Médias seguidas de letras maiúsculas distintas na linha diferem entre si pelo teste Tukey $(p<0,01)$. ( )Número de repetições . 
Com relação ao tempo de duração de estro, o grupo diabético $(26.4 \pm 1)$ apresentou uma duração de estro menor que a dos grupos controle $(48.7 \pm 3.8)$ e hiperinsulinêmico $(49.3 \pm 4.2, p<0,01)$.

Tanto o grupo controle quanto o grupo hiperinsulinêmico apresentaram sinais clínicos de estro bastante evidentes, mucosa vaginal corada, aceitação da monta e discreto balançar da cauda, enquanto que os animais do grupo diabético apresentaram mucosa vaginal mais pálida e os demais sinais mais discretos. Por vezes, o grau de letargia dificultou a identificação da aceitação da monta.

\subsubsection{RESPOSTA OVARIANA}

Como demonstrado na tabela 5 , os animais do grupo diabético apresentaram menor quantidade de $C L(5 \pm 1,1)$ que os dos grupos $(p<0,05)$ controle $(10,3 \pm 1,9)$ e hiperinsulinemia $(11,3 \pm 1)$.

Tabela 5: Média e seus respectivos erros padrões de número de CL, do IQCL, IQE e do total de estruturas colhidas, embriões, mórulas, blastocistos e estruturas degeneradas ou não fecundadas coletados de ovelhas controle, diabéticas e hiperinsulinêmicas superovuladas.

\begin{tabular}{lcccc} 
& Controle & Diabético & hiperinsulinêmico & $\mathrm{P}$ \\
\hline Número de CL & $10.3 \pm 1.9^{\mathrm{A}}(8)$ & $5 \pm 1.1^{\mathrm{B}}(6)$ & $11.3 \pm 1^{\mathrm{A}}(9)$ & 0.013 \\
$\mathrm{IQCL}$ & $1.6 \pm 0.1^{\mathrm{A}}(8)$ & $2.3 \pm 0.3^{\mathrm{B}}(6)$ & $1.3 \pm 0.1^{\mathrm{A}}(9)$ & 0.0008 \\
$\mathrm{IQE}$ & $2 \pm 0.1^{\mathrm{A}}(8)$ & $2.9 \pm 0.2^{\mathrm{B}}(6)$ & $1.7 \pm 0.1^{\mathrm{A}}(9)$ & 0.002 \\
Total de estruturas & $8.3 \pm 1.9^{\mathrm{A}}(8)$ & $3.4 \pm 1^{\mathrm{B}}(6)$ & $8.6 \pm 1^{\mathrm{A}}(9)$ & 0.04 \\
$\begin{array}{l}\text { Colhidas } \\
\text { Total de embriões }\end{array}$ & $7.9 \pm 1.97^{\mathrm{A}}(8)$ & $2.3 \pm 1.2^{\mathrm{B}}(6)$ & $7.4 \pm 1.2^{\mathrm{A}}(9)$ & 0,001 \\
$\begin{array}{l}\text { Colhidos } \\
\text { Mórulas }\end{array}$ & $4.6 \pm 1.8^{\mathrm{A}}(8)$ & $1.2 \pm 0.6^{\mathrm{B}}(6)$ & $3.2 \pm 0.9^{\mathrm{A}}(9)$ & 0,018 \\
$\begin{array}{l}\text { Blastocisto } \\
\text { Estruturas degeneradas }\end{array}$ & $3.3 \pm 1.4^{\mathrm{a}}(8)$ & $1.3 \pm 0.8^{\mathrm{b}}(6)$ & $4.2 \pm 1^{\mathrm{a}}(9)$ & 0,025 \\
ou não fecundados & $0.4 \pm 0.1(8)$ & $1 \pm 0.6(6)$ & $1.1 \pm 0.5(9)$ & 0,087 \\
\hline
\end{tabular}

Médias seguidas de letras maiúsculas distintas na mesma linha diferem entre si pelo teste Tukey IQCL- Índice de qualidade de corpo lúteo; IQE - Índice de qualidade de embrião; CL- Corpo Lúteo.

( ) Número de repetições.

De uma forma geral, os $C L$ do grupo que recebeu insulina se mostraram maiores, mais protuberantes e com coloração vermelha viva. Isto se refletiu em IQCL mais próximo de $1(1,3 \pm 0,1)$. Apesar de ser numericamente menor, o IQCL deste grupo não diferiu do grupo controle $(1,6 \pm 0,1)$. Os animais diabéticos apresentaram IQCL estatisticamente maior $(2,3 \pm 0,3)$ que os demais tratamentos $(p<0,01)$. Este elevado IQCL foi devido à presença de CLs pequenos e pálidos (figura.4). 
O IQE é um índice de qualidade embrionária, atribuído a cada animal, considerando-se o conjunto de estruturas colhidas após a superovulação. Quanto mais distante de 1 for o seu valor, pior será a qualidade em questão. O grupo diabético apresentou IQE superior $(2.9 \pm 0.2)$ aos demais tratamentos, controle $(2 \pm 0.1)$ e hiperinsulinêmicos $(1.7 \pm 0.1), p<0,01$.

Da mesma forma que observado no número de CLs, o grupo diabético também apresentou menor quantidade de estruturas colhidas após a lavagem uterina $(3,3 \pm 2,7), p<0,05$ e menos embriões $(2,3 \pm 2,9) p<0,001$ comparativamente aos grupos controle e hiperinsulinêmicos, que apresentaram respectivamente 8,3 \pm 5,4 e 8,6 \pm 3,3 estruturas e 7,9 \pm 5,3 e 7,4 $\pm 3,6$ embriões.

$\mathrm{Na}$ tabela 5, pode-se observar ainda, que ambos os grupos, hiperinsulinêmicos $(3,2 \pm 2,7)$ e controle $(4,6 \pm 5,1)$ produziram mais mórulas que o grupo diabético $(1,2 \pm 1,3, p<0,05)$. Quando analisados os números de blastocistos, os animais diabéticos (1,3 $\pm 1,9$ mantiveram a baixa resposta, destoando estatisticamente dos demais grupos ( $p<0,05$ ), que produziram 3,3 $\pm 4,1$ no controle e 4,2 $\pm 2,9$ no grupo de hiperinsulinêmicos. Todavia não foi detectada diferença entre os tratamentos quanto ao número de estruturas degeneradas e não fertilizadas.

\subsubsection{AVALIAÇÃO HISTOPATOLÓGICA}

No momento da coleta do material para histopatologia, os fígados dos animais controle e hiperinsulinêmicos não apresentaram alterações em sua aparência geral, enquanto no grupo diabético, possuíam bordas mais arredondadas, discreto aumento de volume, evidenciação da lobulação na superfície e tonalidade mais amarelada (figura 8 A). Ao corte, estas características se mantiveram no parênquima. 

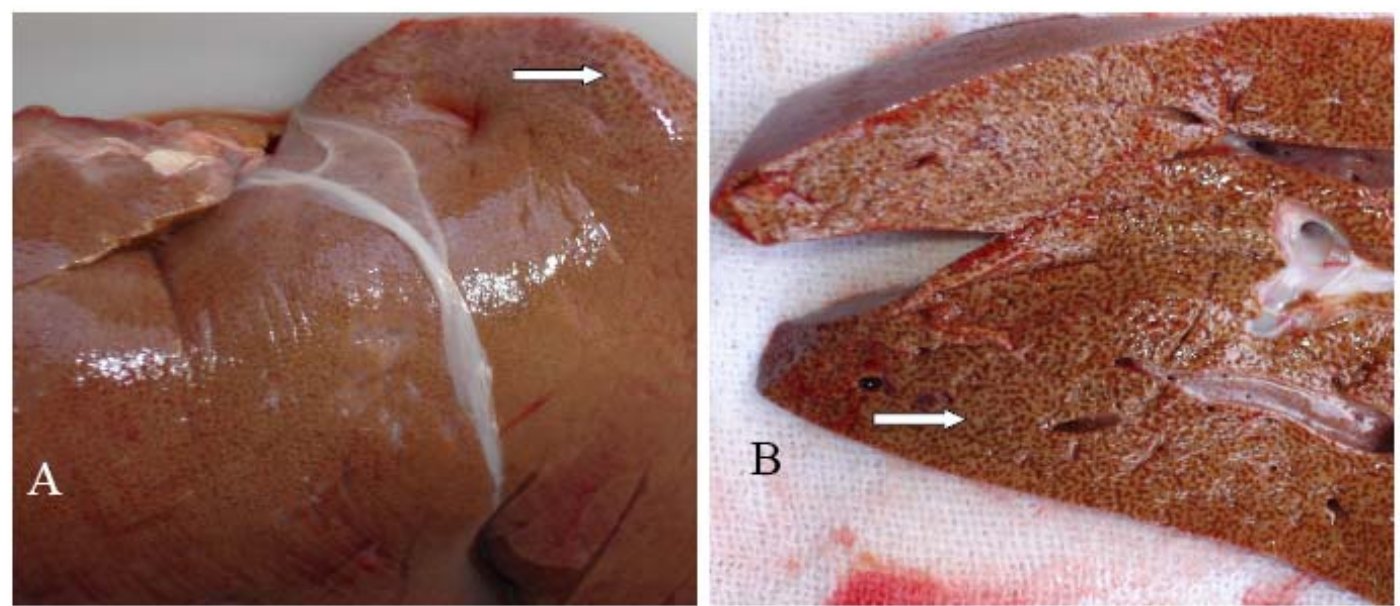

Figura 8: Fígado de ovelha diabética: (A) superfície externa; (B) superfície de corte. Setas branca representam evidenciação da lobulação.

$\mathrm{Na}$ microscopia, das amostras provenientes dos animais diabéticos, em aumento de 250 vezes observou-se intensa vacuolização intracelular próxima à região centrolobular. À medida em que se caminhava com o campo óptico em direção à região periportal, os vacúolos reduziam de tamanho e em número (figura 9A). Em aumento maior, os hepatócitos centrolobulares (figura 9 B) apresentaram tumefação celular e acúmulo de lipídeos no citoplasma, evidenciado pelo vacúolo com imagem negativa de gordura.

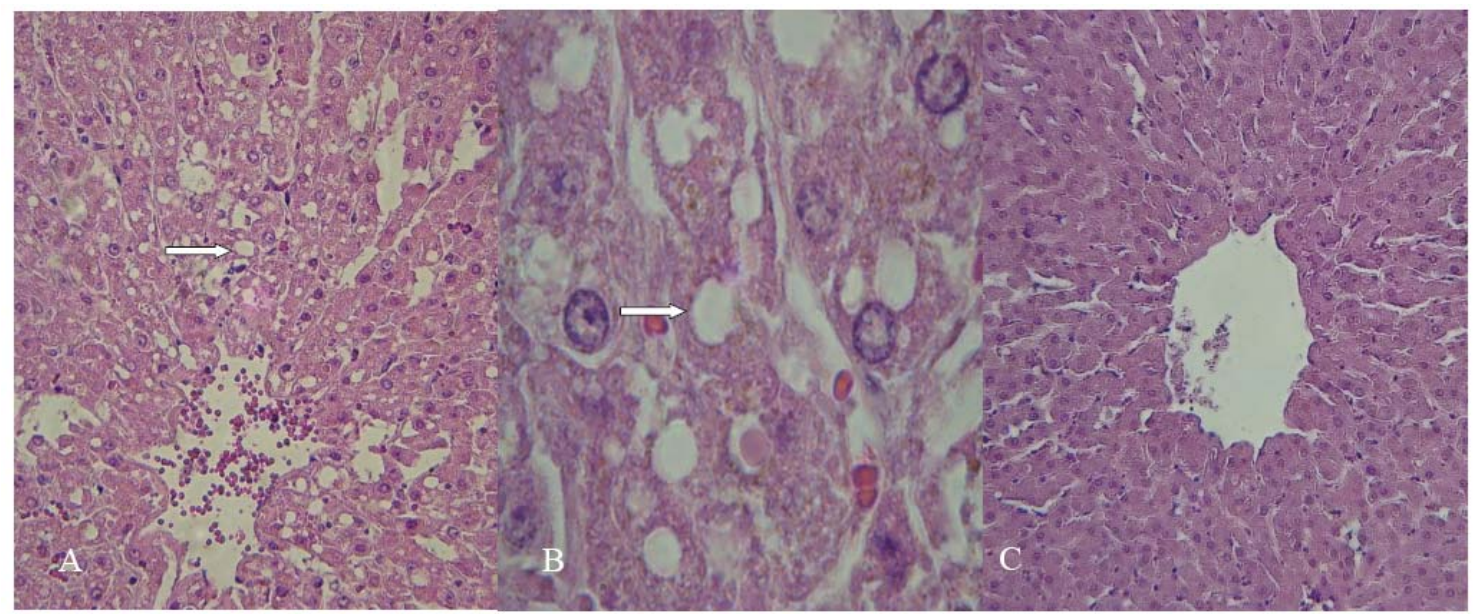

Figura 9: (A) Micrografia da região centrolobular hepática de ovelha (pertencente ao grupo diabético) com esteatose moderada (200x); (B) Hepatócito com de animal (pertencente ao grupo diabético) com esteatose moderada (1000x). (C) Região centrolobular hepática sem alterações histológicas, representativas dos tratamentos controle e hiperinsulinêmico (200x). Setas branca representam vacuolização intracelular.

Nos tratamentos controle e hiperinsulinêmicos não foram encontradas alterações macro ou microscópicas. As lesões identificadas no grupo diabético são compatíveis com um quadro de esteatose hepática moderado.

No momento da colheita embrionária, pode-se verificar que os animais do 
grupo diabético possuíam grande quantidade de CL pequenos (menores que cinco milímetros) e com coloração vermelho alaranjada (grau 3), (14,2\%) de CL grau 2 $(46,6 \%)$ e poucos grau $3(10,1 \%)$. Os tratamentos controle e hiperinsulinêmico apresentaram respectivamente 50 e $72,1 \%$ de $C L$ grau 3. Nas figuras 10 A, B e C podem ser observados ovários com CL graus 1, 2 e 3.

$\mathrm{Na}$ histologia, foi observado, em dois animais do grupo diabético, a presença de folículos com parede parcialmente luteinizada, totalizando cinco estruturas. Achado semelhante ocorreu em dois animais hiperinsulinêmicos, que juntos externaram dois folículos com parede parcialmente luteinizada (figura $10 \mathrm{D}$ e F). Tal ocorrência não foi observada no grupo controle.

Ainda no grupo diabético, foi encontrado um folículo não ovulado, porém plenamente luteinizado, apresentando um ovócito e transição direta entre células luteínicas e da teca. Entretanto, trata-se de achado ocasional, uma vez que a técnica empregada não foi desenvolvida para esse fim.

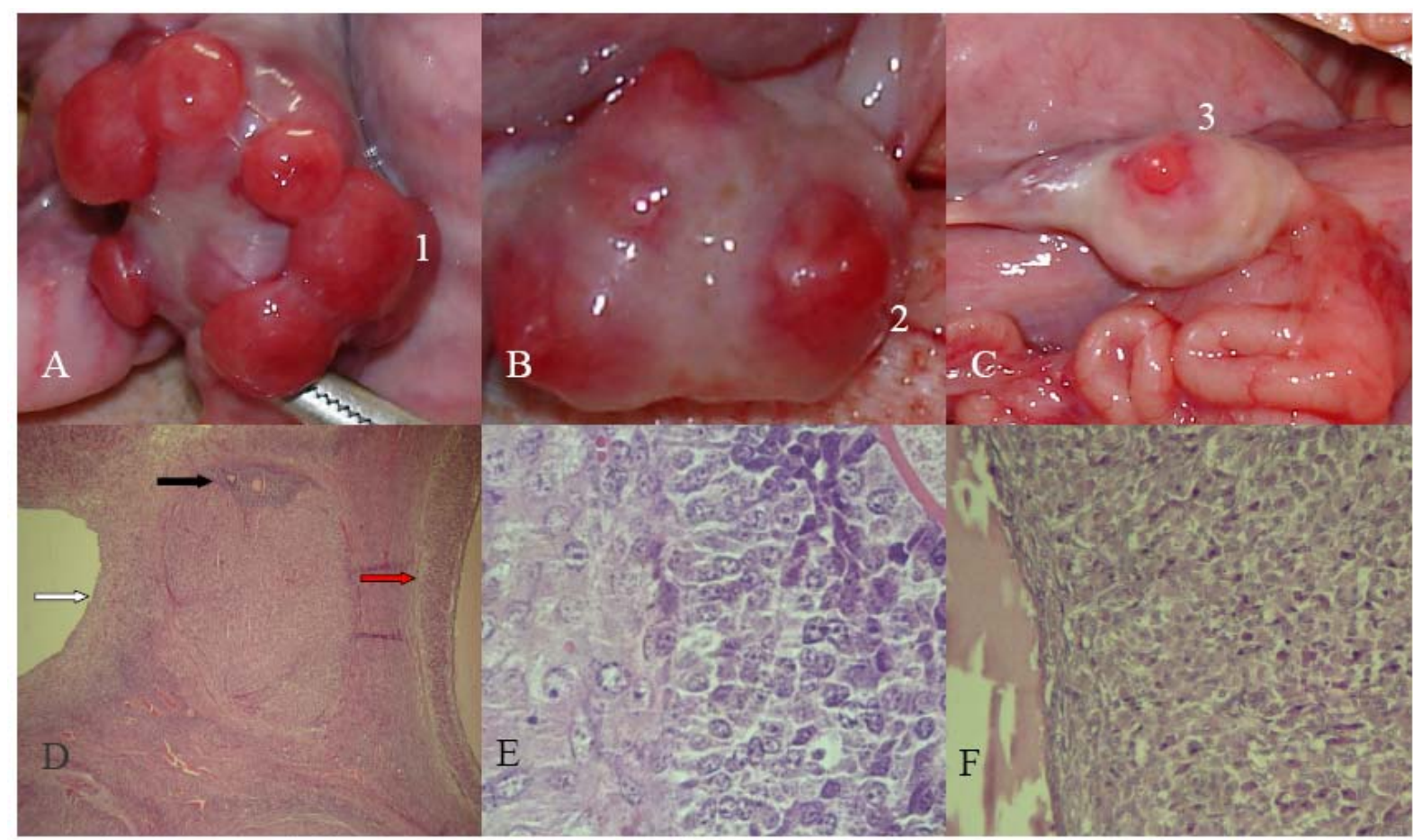

Figura 10: (A) Ovário ovino apresentando CL grau 1; (B) Ovário ovino apresentando $C L$ grau 2; (C) Ovário ovino apresentando CL grau 3; (D) Corte histológico de CL do grupo diabético com folículo luteinizado (seta preta), folículo com parede parcialmente luteinizada (seta vermelha) e folículo terciário (seta branca) (25x); (E) Transição direta entre células luteínicas e celulas da teca no folículo não ovulado (1000x); (F) Detalhe do folículo com parede parcialmente e grande número de células em apoptose (200x).

$\mathrm{Na}$ tabela 6 estão expressos os resultados das avaliações citométricas. As LLC dos animais do grupo diabético apresentaram menor área $(336,9 \pm 26,8)$ que as dos grupos controle e hiperinsulinêmicos, com respectivamente 438,9 \pm 16,8 e 450,9 
$\pm 26,7 \mu m^{2} \quad(p<0,05)$. O número de células apoptóticas por campo avaliado foi superior $(p<0,05)$ no grupo diabético $(1,07 \pm 0,4)$, quando comparado aos tratamentos controle $(0,3 \pm 01)$ e hiperinsulinêmico $(0,48 \pm 0,2)$. As demais variáveis expressas na tabela não diferiram estatisticamente entre si.

Ao submeter os dados à análise de correlação, o número de células apoptóticas por campo apresentou correlação negativa com o diâmetro maior das SLC $\left(R^{2}=-0,61 ; p<0,05\right)$, com a área de tecido luteínico $\left(R^{2}=-0,63 ; p<0,05\right)$ e com a produção de progesterona $\left(R^{2}=-0,60 ; p<0,05\right)$. Por outro lado, o número de células apoptóticas por campo correlacionou-se positivamente com a área de tecido conjuntivo e fibroblastos $\left(R^{2}=0,71 ; p<0,01\right)$ e a área de tecido conjuntivo e fibroblastos foi negativamente correlacionada com a produção de progesterona $\left(R^{2}=-\right.$ $0,64 ; p<0,05)$ e com área de tecido luteínico $\left(R^{2}=-0,87 ; p<0,01\right)$.

Tabela 6: Média da área e do diâmetro maior das LLC e SLC, número de células apoptóticas por campo e percentagem de células endotelial e pericito, tecido luteínico e tecido conjuntivo e fibroblasto, com seus respectivos erros padrões em corpos lúteos de ovelhas controle, diabéticas e hiperinsulinêmicas superovuladas

\begin{tabular}{|c|c|c|c|c|}
\hline Dia & Controle & Diabético & Hiperinsulinêmico & $P$ \\
\hline Área LLC $\left(\mu \mathrm{m}^{2}\right)$ & $438.9 \pm 16.8^{\mathrm{A}}(3)$ & $336.9 \pm 26.8^{\mathrm{B}}(6)$ & $450.9 \pm 26.7^{A}(4)$ & 0.02 \\
\hline Diâmetro LLC maior $(\mu \mathrm{m})$ & $33 \pm 0.6(3)$ & $29.7 \pm 1.5(6)$ & $35.6 \pm 1.2(4)$ & 0.085 \\
\hline Área da SLC $\left(\mu \mathrm{m}^{2}\right)$ & $119.5 \pm 3.3(3)$ & $101.7 \pm 6.1(6)$ & $133.8 \pm 13.1(4)$ & 0.07 \\
\hline Diâmetro maior SLC $(\mu \mathrm{m})$ & $17.1 \pm 1.3(3)$ & $14.4 \pm 0.4(6)$ & $17 \pm 1(4)$ & 0.078 \\
\hline $\begin{array}{l}\text { Células apoptóticas por } \\
\text { campo }\end{array}$ & $0.3 \pm 0.1^{\mathrm{B}}(3)$ & $1.7 \pm 0.4^{\mathrm{A}}(6)$ & $0.48 \pm 0.2^{\mathrm{B}}(4)$ & 0.049 \\
\hline $\begin{array}{l}\text { Célula endotelial e pericito } \\
(\%)\end{array}$ & $2.5 \pm 0.2(3)$ & $1.4 \pm 0.3(6)$ & $1.5 \pm 0.3(4)$ & 0.21 \\
\hline $\begin{array}{l}\text { Tecido conjuntivo } \\
\text { fibroblasto }(\%)\end{array}$ & $11.6 \pm 0.4(3)$ & $17.4 \pm 1.6(6)$ & $12.6 \pm 2.4(4)$ & 0.117 \\
\hline Tecido Luteínico (\%) & $85.8 \pm 0.4(3)$ & $82.61 \pm 1.3(6)$ & $86.9 \pm 2.7(4)$ & 0.25 \\
\hline
\end{tabular}

Médias seguidas de letras maiúsculas distintas na mesma linha diferem entre si pelo teste Tukey. ( ) Número de repetições.

Nos animais diabéticos, a área e o diâmetro maior das LLC foram correlacionados positivamente com a área de células endoteliais e pericitos, possuindo respectivamente $R^{2}=0,88(p<0,05)$ e $R^{2}=0,99(p<0,01)$, enquanto que $o$ número de células apoptóticas foram correlacionadas negativamente com a área de tecido luteínico $\left(R^{2}=-0,97 ; p<0,01\right)$.

A figura $11 \mathrm{C}$ evidencia uma LLC em processo de apoptose, apresentando citoplasma fortemente eosinofílico e retraído, núcleos picnóticos e aumento do espaço intercelular. Está presente ainda discreta vacuolização no citoplasma de 
células adjacentes.

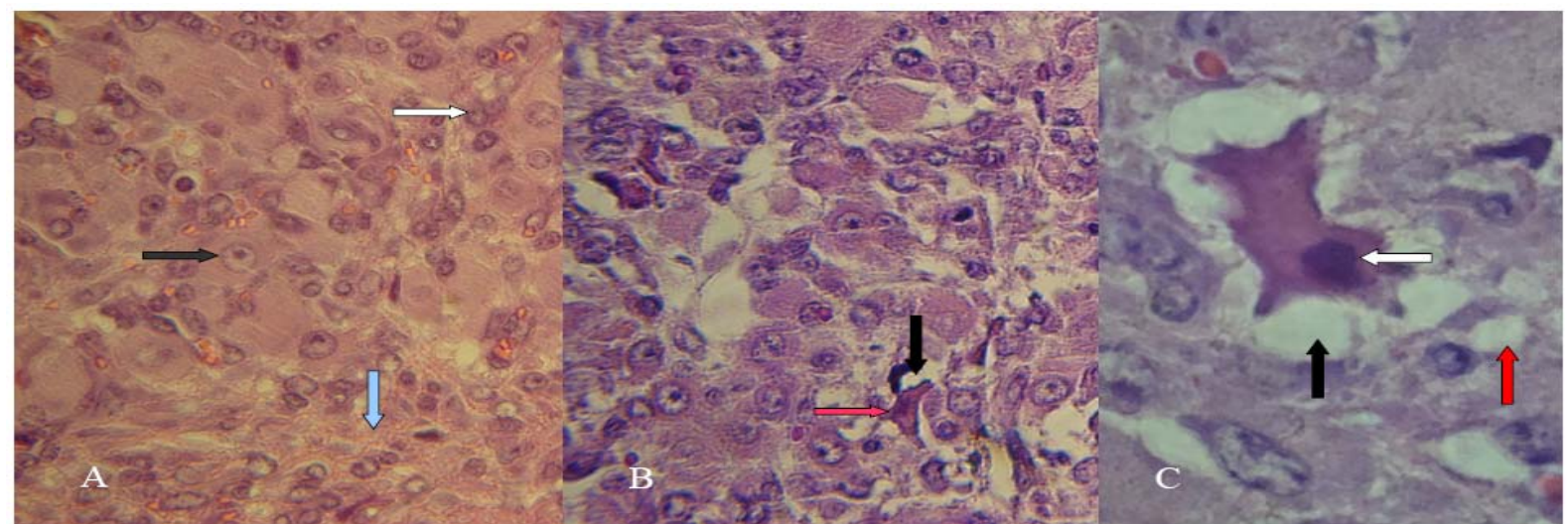

Figura 11: (A) Corte histológico de CL de ovelha compatível com os grupos controle e hiperinsulinêmico: região rica em tecido conjuntivo (seta azul), LLC típica (seta cinza) e SLC típica (seta branca), 200x; (B) Corte histológico de CL de ovelha diabética: célula apoptótica (seta vermelha) e retração celular (seta branca), 200x; @ Célula LLC em apoptose, com núcleo picnótico (seta branca), retração célula (seta preta) e área de vacuolização celular (seta vermelha).

Na grande maioria das lâminas pertencentes ao grupo diabético, as células do tecido luteínico se apresentavam retraídas, com pontos de vacuolização e com um início de desorganização, por vezes dificultando as análises de citometria (figura 11B). Nos demais tratamentos o tecido luteínico se apresentou sem alterações (figura $11 \mathrm{~A}$ ).

\subsubsection{CONCENTRAÇÃO PLASMÁTICA DE PROGESTERONA}

Nas análises das concentrações plasmáticas de progesterona nos dias: D-2, D-1, D.0, D.1, D.2, D.3, D.4, D.5, considerando-se o D.0 como o último dia de manifestação de estro das ovelhas, foi identificada interação entre tratamento e tempo $(P<0,01)$. Na tabela 7 , pode ser visualizada a concentração de progesterona segundo, tempo em cada tratamento.

Tanto o grupo diabético $(0.7 \pm 0.1 \mathrm{ng} / \mathrm{ml})$, quanto o hiperinsulinêmico $(0.8 \pm 0.2 \mathrm{ng} / \mathrm{mL})$ apresentaram maior concentração plasmática de progesterona que o grupo controle $(0.2 \pm 0.1 \mathrm{ng} / \mathrm{mL})$, no momento da remoção do pessário vaginal ( $p<0,05)$.

Durante o estro (D-1 e D.0) e no primeiro dia após o estro (D.1), não foram encontradas diferenças significativas entre os tratamentos. 
Tabela 7: Média de progesterona plasmática em $\mathrm{ng} / \mathrm{mL}$ e seus respectivos erros padrões em ovelhas controle, diabéticas e hiperinsulinêmicas superovuladas e seu respectivo erro padrão

\begin{tabular}{lcccc}
\hline Dia & $\begin{array}{c}\text { Controle } \\
(\mathrm{ng} / \mathrm{mL})\end{array}$ & $\begin{array}{c}\text { Diabétco } \\
(\mathrm{ng} / \mathrm{mL})\end{array}$ & $\begin{array}{c}\text { Hiperinsulinêmico } \\
(\mathrm{ng} / \mathrm{mL})\end{array}$ & $\mathrm{P}$ \\
\hline D-2 & $0.2 \pm 0.1^{\mathrm{B}}(9)$ & $0.7 \pm 0.1^{\mathrm{A}}(6)$ & $0.8 \pm 0.2^{\mathrm{A}}(9)$ & 0.029 \\
D-1 & $0.19 \pm 0.1(9)$ & $0.5 \pm 0.2(6)$ & $0.4 \pm 0.1(9)$ & 0.056 \\
D.0 & $0.4 \pm 0.1(9)$ & $0.5 \pm 0.1(6)$ & $0.5 \pm 0.1(9)$ & 0.22 \\
D.1 & $1.7 \pm 0.5(9)$ & $1 \pm 0.2(6)$ & $2.4 \pm 0.4(9)$ & 0.13 \\
D.2 & $5.4 \pm 1.3^{\mathrm{A}}(9)$ & $2.2 \pm 0.7^{\mathrm{B}}(6)$ & $6.4 \pm 0.9^{\mathrm{A}}(9)$ & 0.006 \\
D.3 & $11 \pm 2.2^{\mathrm{A}}(9)$ & $4.2 \pm 1^{\mathrm{B}}(6)$ & $12.9 \pm 2.3^{\mathrm{A}}(9)$ & 0.003 \\
D.4 & $23.2 \pm 3.5^{\mathrm{A}}(9)$ & $7.5 \pm 4^{\mathrm{B}}(6)$ & $22.7 \pm 2.5^{\mathrm{A}}(9)$ & 0.0002 \\
D.5 & $24.8 \pm 3.7^{\mathrm{A}}(7)$ & $7.6 \pm 3.1^{\mathrm{B}}(5)$ & $32.1 \pm 3.9^{\mathrm{A}}(7)$ & 0.0006 \\
\hline
\end{tabular}

Médias seguidas de letras maiúsculas distintas na mesma linha diferem entre si pelo teste Tukey.

( ) Número de repetições.

Como observado na figura 12, a partir do D.2 a concentração de progesterona aumentou significativamente, nos três tratamentos em relação ao D1. Desse momento em diante, até o D.5, o grupo diabético apresentou concentração plasmática de progesterona menor $(p<0,01)$ que os demais tratamentos, que não diferiram entre si.

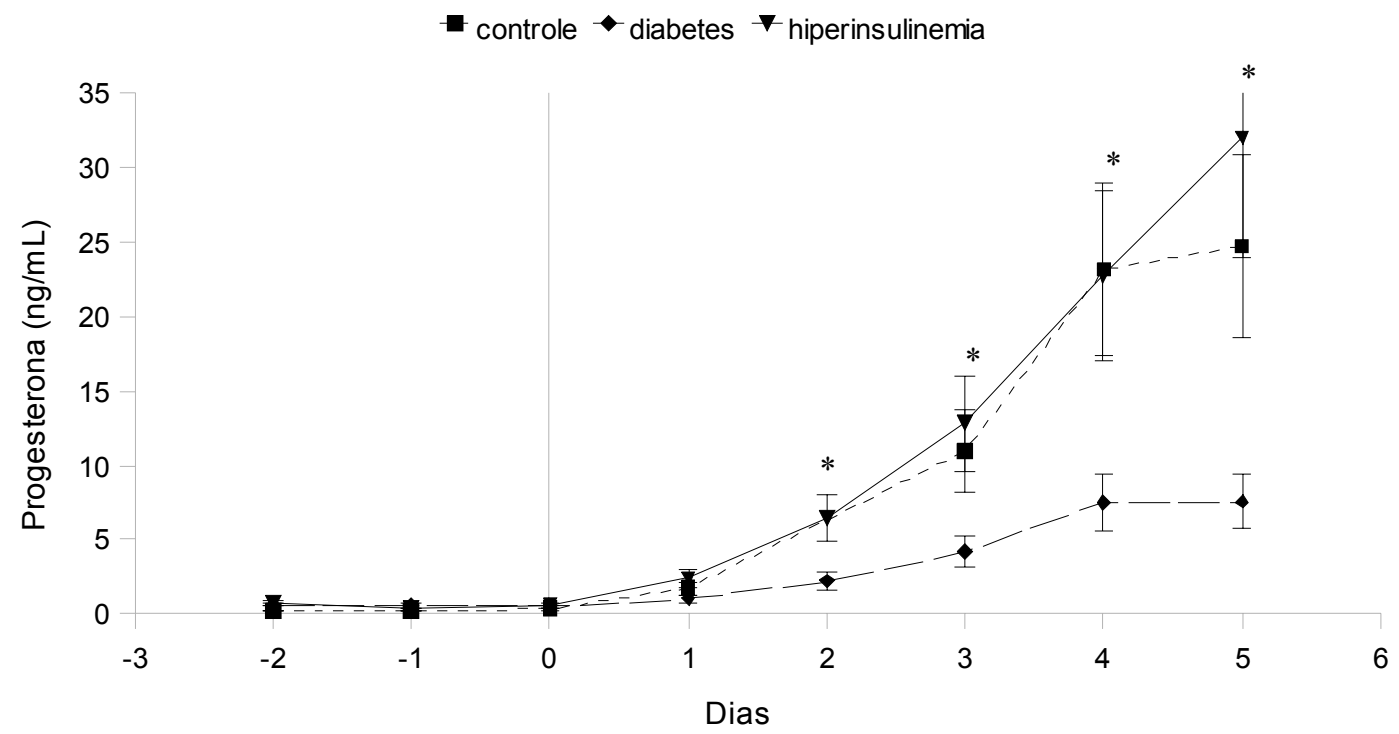

Figura 12: Concentração plasmática de progesterona de ovelhas diabéticas, hiperinsulinêmicas e controle superovuladas.

A progesterona plasmática foi correlacionada negativamente com o IQE $\left(R^{2}=0,45, P<0,05\right)$ e IQCL $\left(R^{2}=0,47, P<0,05\right)$ e, positivamente com o número de $C L$ 
$\left(R^{2}=0,53, P<0,01\right)$.

Ao correlacionar progesterona e insulina, não foi observado um comportamento semelhante entre os tratamentos. Enquanto os grupos controle e hiperinsulinêmicos não apresentaram correlação, no grupo diabético essa se mostrou positiva e bastante elevada $\left(R^{2}=0,88, P<0,01\right)$.

\subsection{EXPERIMENTO 2}

\subsubsection{CONFECÇÃO E CARACTERIZAÇÃO DAS NANOPARTÍCULAS}

Como observado na figura 13 , a avaliação por DLS, foi indicativa de que 92\% das nanopartículas contendo insulina apresentaram diâmetro médio menor que $100 \mathrm{~nm}$, enquanto que $98,6 \%$ das nanopartículas brancas se enquadravam neste parâmetro. O maior diâmetro de partículas nas formulações com e sem insulina, foram de respectivamente $396 \mathrm{~nm}$ e $295 \mathrm{~nm}$. Pode -se observar também, que a inclusão da insulina ao sistema deslocou o gráfico de tamanho das partículas para direita.

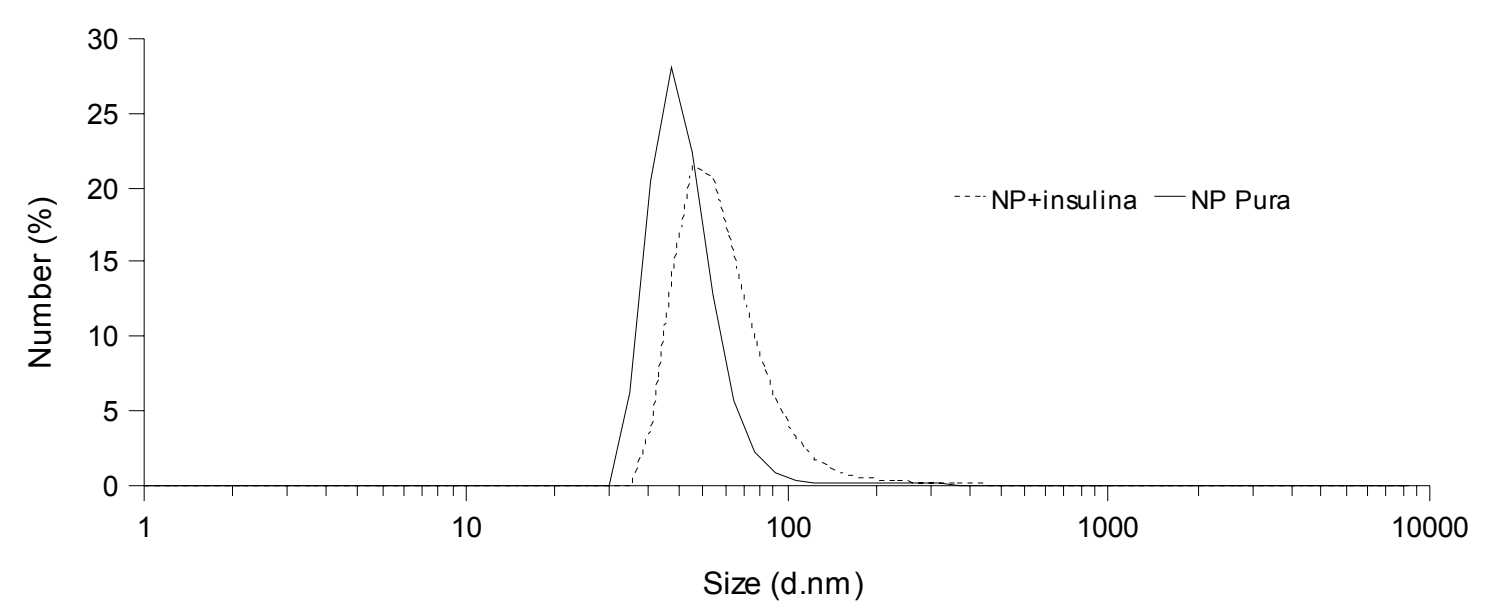

Figura 13: Distribuição de tamanho de nanopartículas brancas (linha contínua) e de nanopartículas contendo insulina (linha tracejada).

O índice de polidispersão (IPD) e potencial Zeta encontrados na amostra de nanopartícula branca foram respectivamente de 0,395 0,07 e $+40,5 \pm 0,9 \mathrm{mV}$, por sua vez a amostra contendo insulina apresentou IPD de 0,45 0,09 e potencial Zeta de $+37 \pm 1,1 \mathrm{mV}$.

$\mathrm{Na}$ microscopia eletrônica de varredura, tanto nanopartículas contendo insulina (figura $14 \mathrm{~A}$ ) quanto as brancas (figura $14 \mathrm{~B}$ ) se mostram com formato esférico, de tamanho relativamente homogêneo e com diâmetro predominantemente 
inferior à $100 \mathrm{~nm}$. Contudo, as nanopartículas que possuíam insulina se apresentaram com tamanho discretamente superior em relação às nanopartículas brancas. As amostras de nanopartículas incorporadas na matriz lipídica não suportaram a tensão do equipamento de MEV e se deterioraram durante o processamento, inviabilizando a geração de suas imagens.

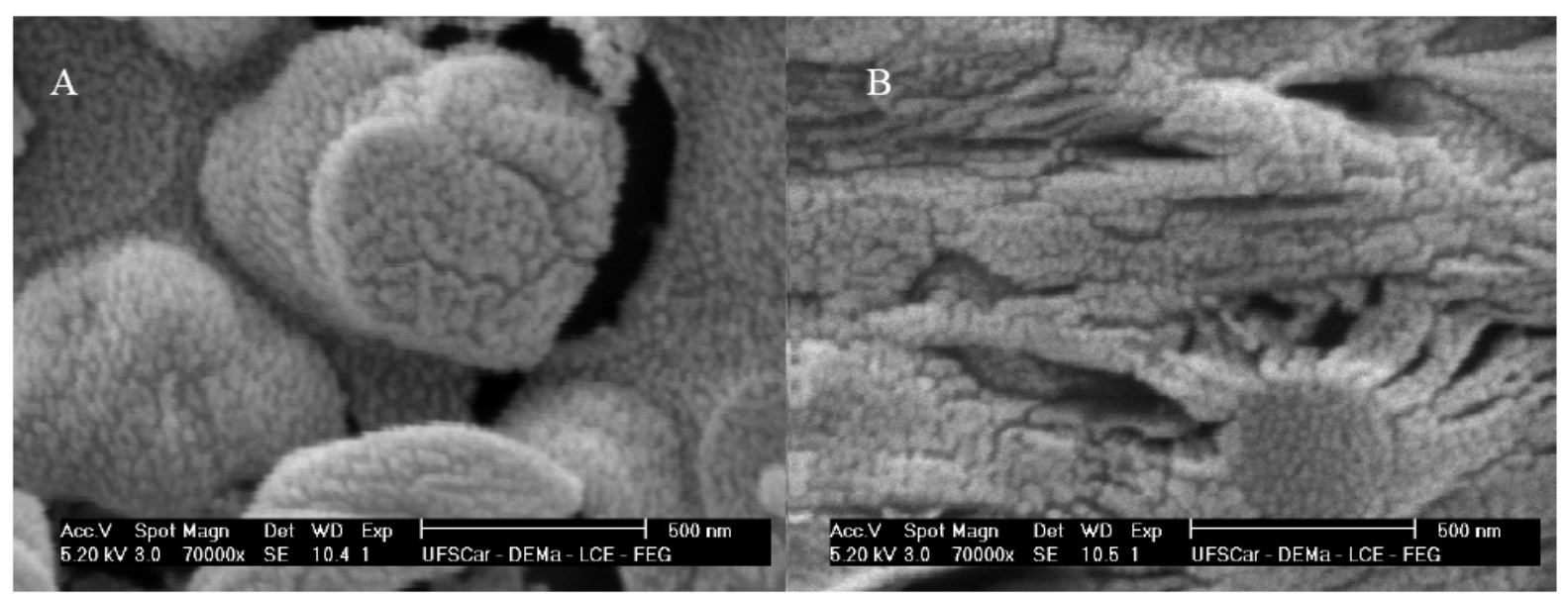

Figura 14: Eletromicrografia de Varredura (A) Nanopartículas de quitosa/TPP contendo insulina e (B) nanopartículas de quitosana/TPP (70.000x).

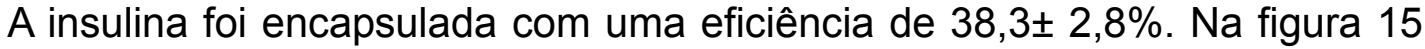
pode-se observar um cromatograma da insulina durante o ensaio de liberação in vitro. Nota-se um único pico, bem definido, no tempo de retenção 2,08 minuto, compatível com apenas uma proteína no meio de liberação.

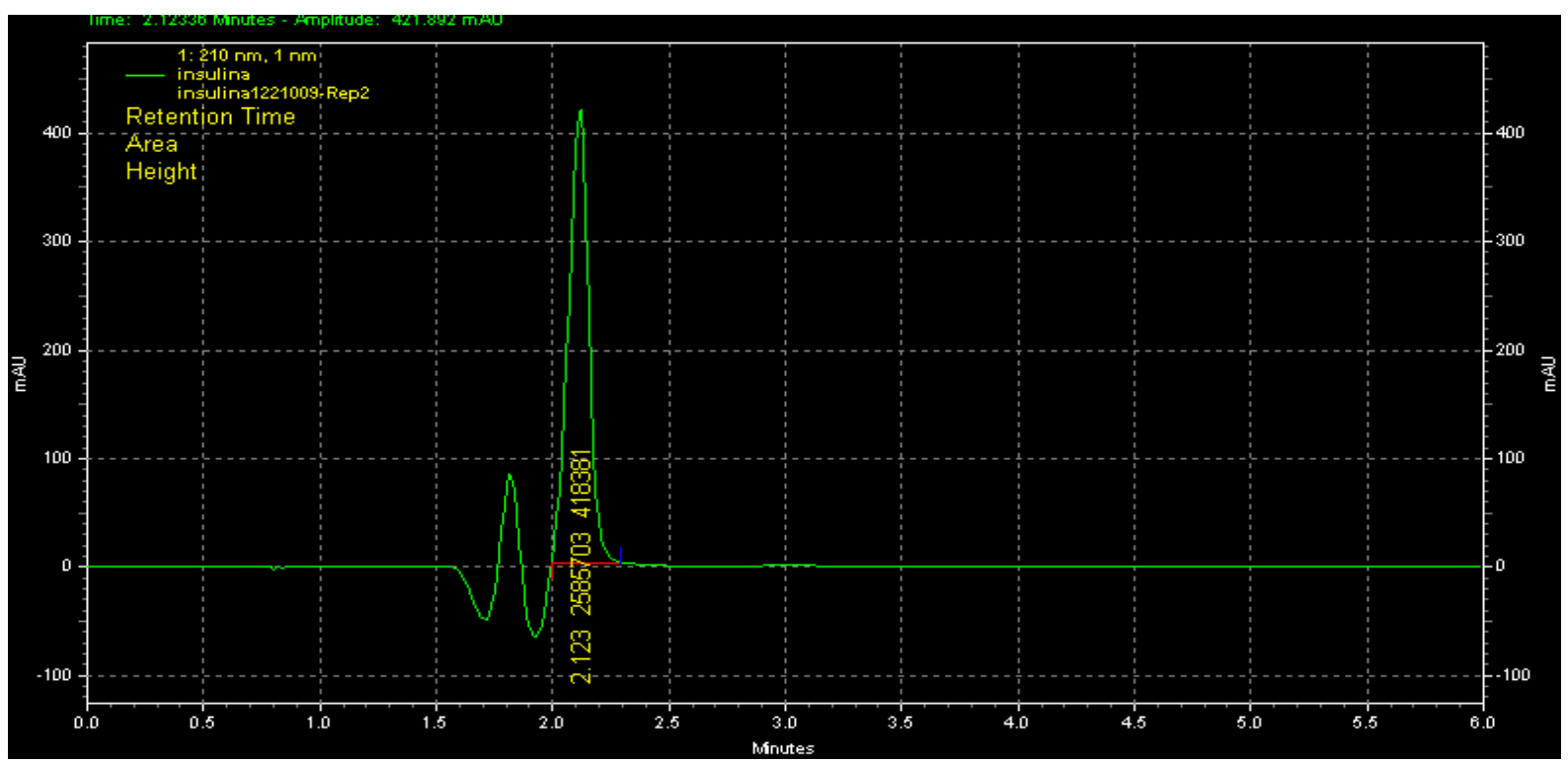

Figura 15: Cromatograma da insulina amostrada durante o ensaio de liberação in vitro.

Os espectros de infravermelho da quitosana, do TPP, da insulina, da nanopartícula branca e da insulina nanoencapsulada podem ser visualizados na 
figura 16. A insulina apresenta dois picos vibracionais, de absorção bem definidos, um na banda carbonil $1654 \mathrm{~cm}^{-1}$, que também é comum à quitosana e outro na banda amina II, em $1541 \mathrm{~cm}^{-1}$, principalmente devido ao estiramento vibracional da ligação $(C=0)$, característico de proteínas.

Além da banda carbonil, a quitosana exibe uma segunda banda característica, referente à protonação do grupamento amino, em $1575 \mathrm{~cm}^{-1}$ (curvatura $\mathrm{N}-\mathrm{H})$.

No espectro do TPP pode ser observado um pico, bastante evidente, entre 1216 e $1094 \mathrm{~cm}^{-1}$, referente ao estiramento $P=O$. Em $910 \mathrm{~cm}^{-1}$ fica evidenciada ainda um estiramento, referente à ligação P-O-P.

Tanto nas nanopartículas brancas, quanto nas contendo insulina, pode-se observar o deslocamento da banda $1651 \mathrm{~cm}^{-1}$ e a evidenciação da banda amina II em $1541 \mathrm{~cm}^{-1}$. Ocorre ainda um alargamento da base nas regiões entre 1284 e 1032 $\mathrm{cm}^{-1}$.

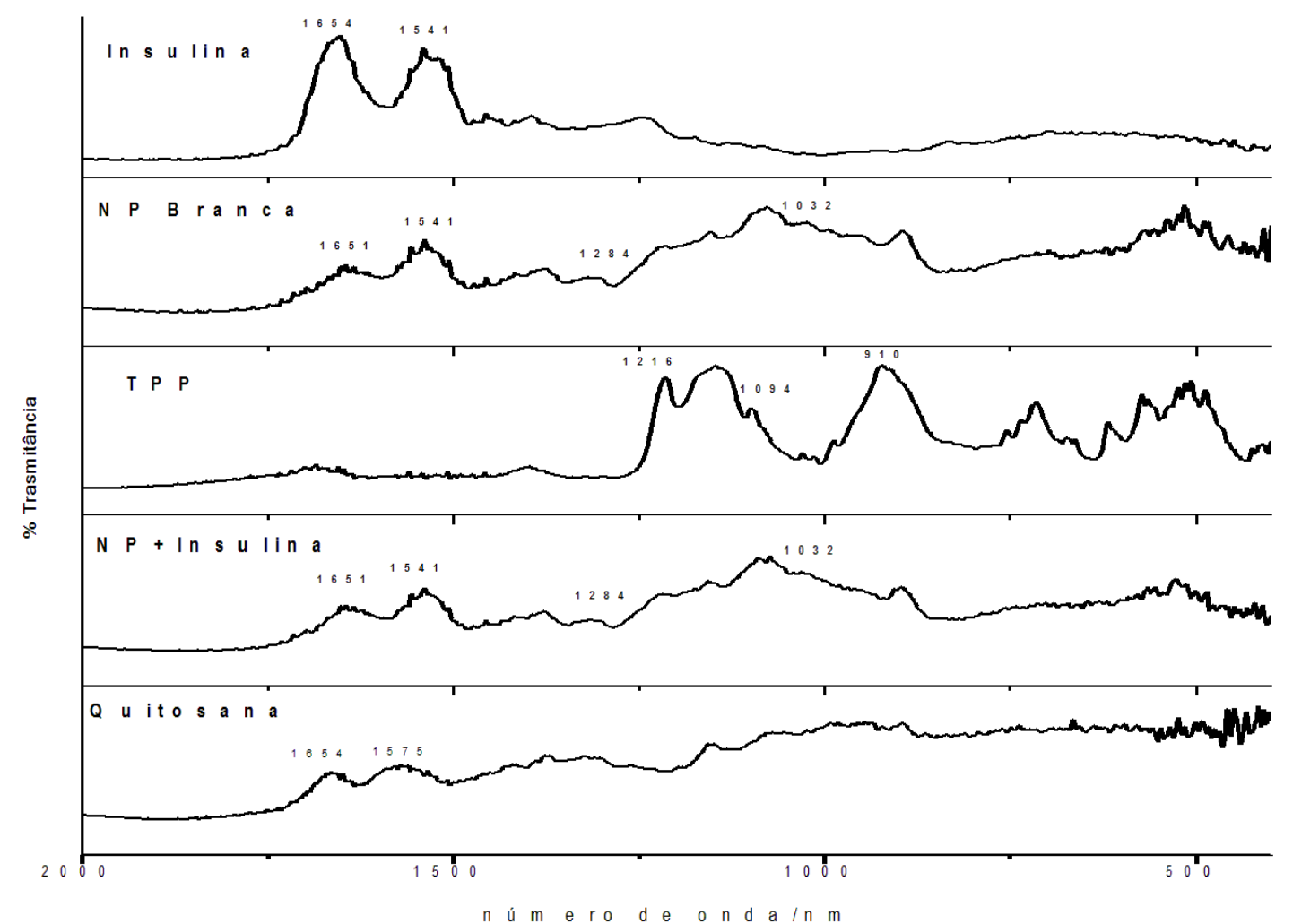

Figura 16: Espectro infravermelho da insulina, nanopartícula branca, tripolifosfato de sódio (TPP), nanopartícula contendo insulina e quitosana. 


\subsubsection{ENSAIOS DE LIBERAÇÃO}

O padrão de liberação in vitro da insulina nanoestruturada simples e incorporada em uma matriz lipídica, em função do tempo, foi determinado em $\mathrm{pH} 7,4$ e pode ser visualizada na figura 17.

O sistema constituído de insulina nanoencapsulada apresentou um pico de liberação de $57,2 \pm 4,1 \%$ na primeira hora de ensaio, atingindo $78,7 \% \pm 4,3 \%$ ao final da segunda hora. Este valor continuou aumentando suavemente até atingir 92,1 $\pm 3,01 \%$ em 24 horas de ensaio.

A insulina nanoencapsulada, incorporada em matriz lipídica, liberou na primeira hora de ensaio $7,4 \pm 4,1 \%$. A partir da segunda hora de avaliação os valores se estabilizaram em $11,8 \% \pm 6,3 \%$, seguidos de pequenas flutuações crescentes até a vigésima quarta hora de ensaio, na qual apresentavam 15,6 \pm $4,9 \%$.

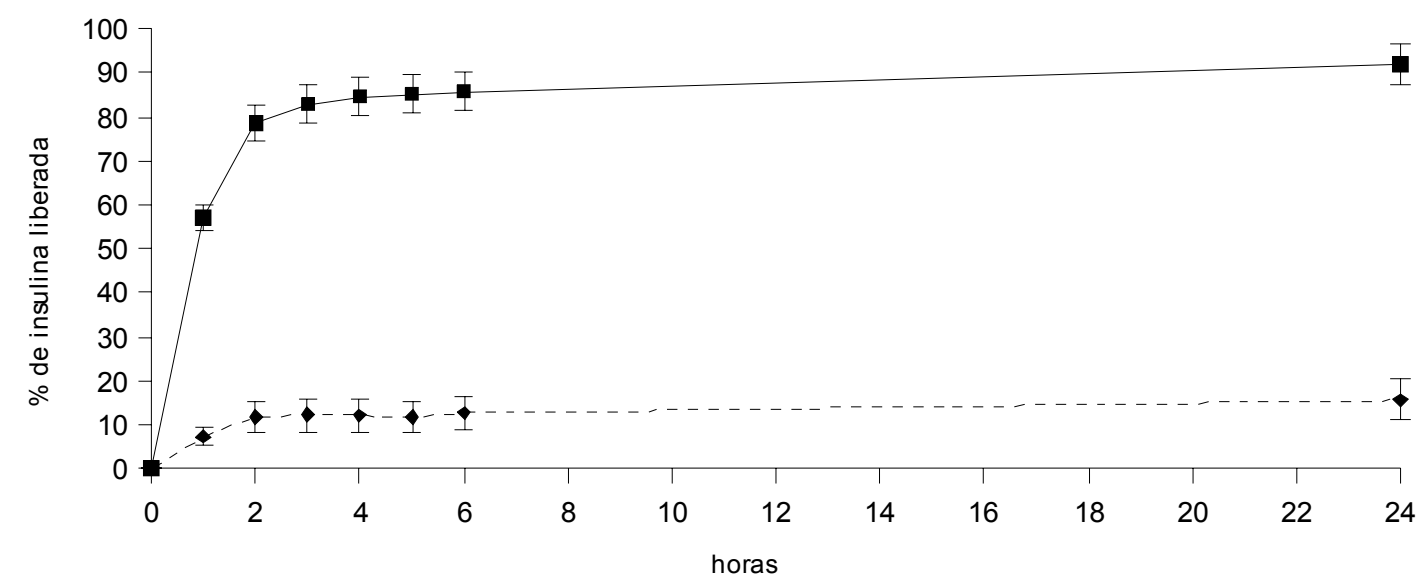

Figura 17: Percentagem cumulativa de insulina liberada in vitro sob $\mathrm{pH} 7,4$. Linho contínua nanopartículas contendo insulina, linha tracejada nanopartículas contendo insulina incorporada em matriz lipídica.

Foi avaliado o padrão de liberação in vivo e o comportamento glicêmico de diferentes formulações, com intuito de identificar a viabilidade de permeação de mucosa gastrintestinal e o efeito de liberação sustentado da insulina nanoestruturada.

$\mathrm{Na}$ figura 18, estão expressos os resultados dos animais controle, que receberam $8 \mathrm{~mL}$ de soro fisiológico subcutâneo. Ao longo do ensaio, a insulinemia apresenta uma discreta elevação a partir da quarta hora de ensaio e, retorna ao valor próximo do iniciais na décima quarta hora, mantendo-se assim até o término do ensaio. Por sua vez, os valores glicêmicos apresentam comportamento semelhante, 
apresentando uma suave elevação de aproximadamente $20 \%$ entre quatro e

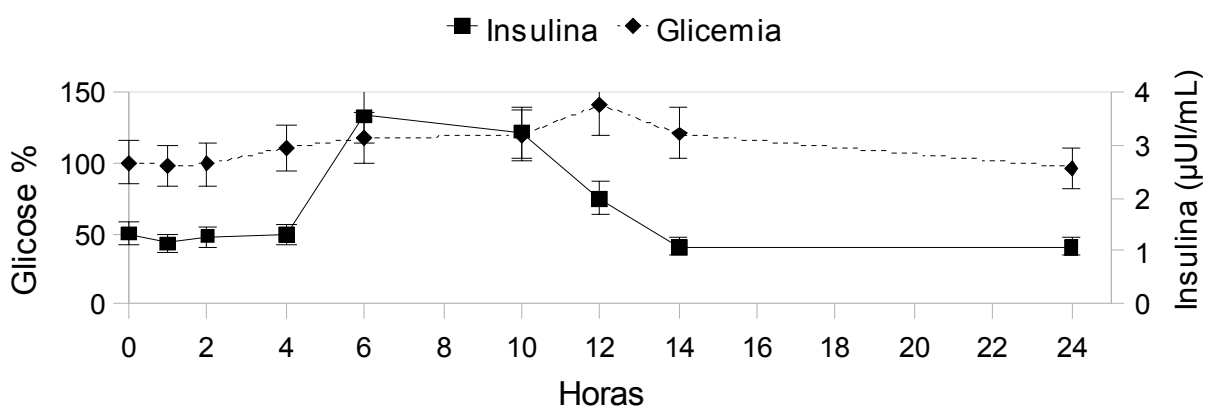

quatorze horas.

Figura 18: Média da concentração plasmática de insulina e de \% de glicose em função da linha de base, após a administração subcutânea de $8 \mathrm{~mL}$ soro fisiológico.

A formulação avaliação da formulação composta exclusivamente de nanopartículas pura (branca) pode ser observada na figura 19 . O comportamento das variáveis insulinemia e glicemia foram semelhantes aos observados nos animais controle.

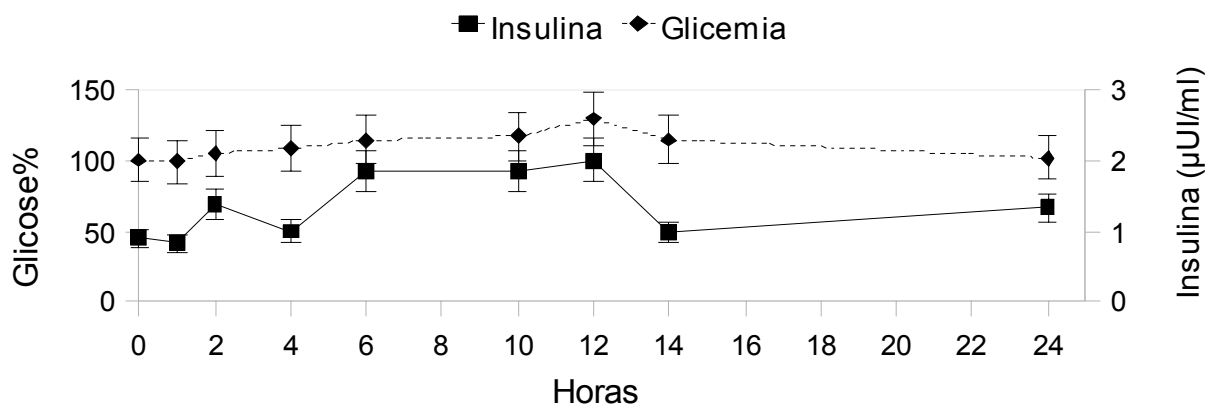

Figura 19: Média da concentração plasmática de insulina e de \% de glicose em função da linha de base, após a administração subcutânea de nanopartículas branca.

Os animais que receberam 2,5 Ul/kg de insulina (S.C.) apresentaram uma rápida elevação plasmática deste hormônio, atingindo em uma hora pós aplicação valor de $828,9 \pm 23,9 \mu \mathrm{Ul} / \mathrm{ml}$ que, caíram suavemente até a sexta hora pós aplicação $(629,6 \pm 99,4)$. A partir deste momento a queda se tornou mais acentuada atingindo a concentração de $8,72 \pm 1,93 \mu \mathrm{Ul} / \mathrm{ml}$ em quatorze horas de ensaio. $O$ tratamento completou 24 horas de ensaio com valores plamáticos de insulina próximo ao inicial (figura 20). Nesse tratamento um animal apresentou letargia da resposta aos estímulos externos entre 6 e 10 horas, período em que apresentou glicemia inferior. 


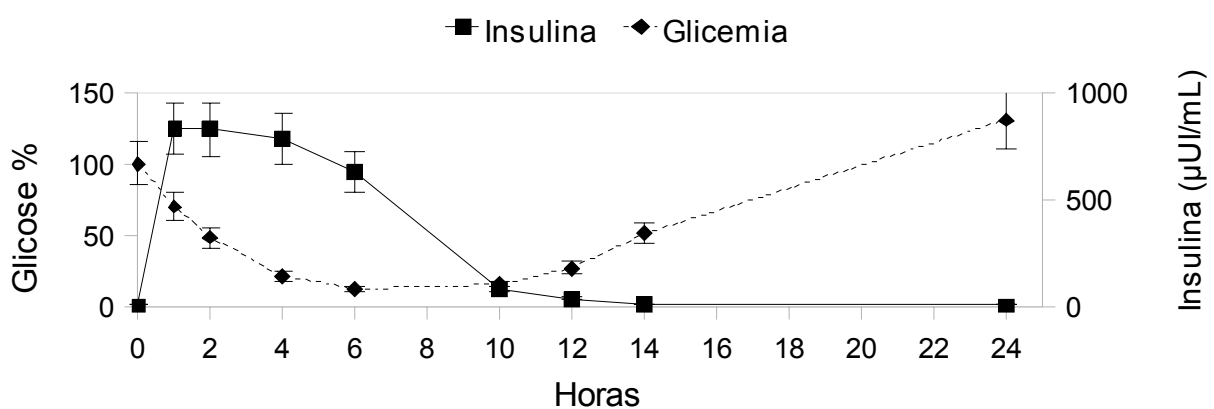

Figura 20: Média da concentração plasmática de insulina e de \% de glicose em função da linha de base, após a administração subcutânea de $2,5 \mathrm{Ul} / \mathrm{kg}$ de insulina.

Os valores glicêmicos apresentaram comportamento invertido ao da insulina, porém menos aguda. A partir da aplicação, a glicemia apresentou redução de valores, atingindo ao valor mínimo $11,8 \pm 4,6 \%$ na sexta hora de ensaio. A partir desse momento, retoma o crescimento atingindo $50,64 \pm 3,6 \%$ da linha de base em

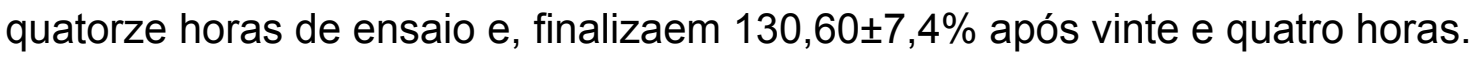

Os animais que receberam 2,5 UI de insulina pela via subcutânea na forma de nanopartícula (figura 21) apresentaram um aumento na insulina plasmática até a segunda hora de ensaio $(77,55 \pm 22,14 \mu \mathrm{Ul} / \mathrm{ml})$. Com quatro horas, sua concentração regride para $32,4 \pm 6,5 \mu \mathrm{Ul} / \mathrm{ml}$, diminuindo suavemente até $15,6 \pm 1,6 \mu \mathrm{Ul} / \mathrm{ml}$ na décima quarta hora. Ao término do ensaio de liberação se estabilizou em concentração semelhante a dos demais tratamentos.

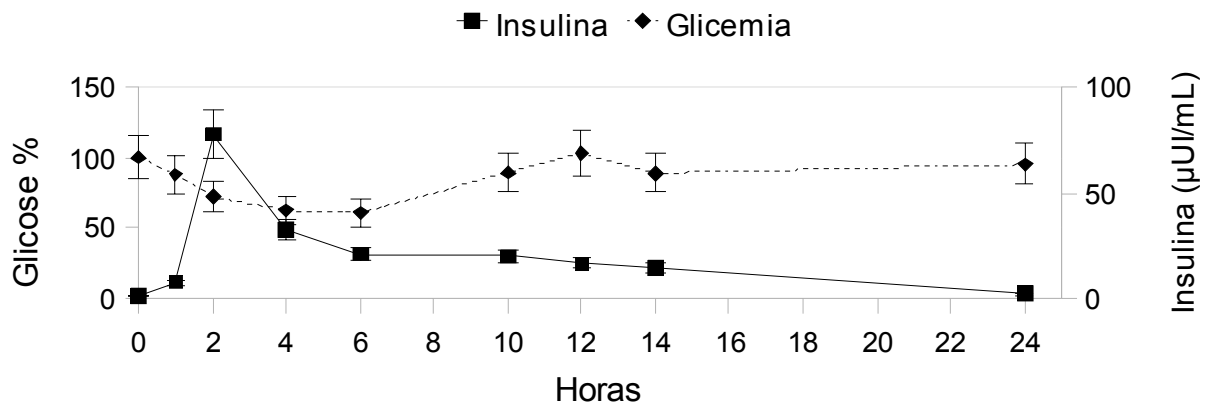

Figura 21: Média da concentração plasmática de insulina e de \% de glicose em função da linha de base, após a administração subcutânea de $2,5 \mathrm{UI} / \mathrm{kg}$ de insulina nanoestruturada.

Após a aplicação da formulação, o menor valor glicêmico ocorreu na sexta hora de ensaio $(60,8 \pm 3,2 \%)$, quando então retomou o aumento, apesentando um retorno da glicemia à linha de base $(102,95 \pm 3,2 \%)$ na décima segunda hora, com uma subseqüente queda à $88,85 \pm 4,2 \%$ na décima quarta hora e encerrada a avaliação próximo ao valor da linha de base.

O padrão da insulinemia e da glicemia dos animais que receberam $50 \mathrm{UI} / \mathrm{kg}$ 
de insulina em $8 \mathrm{~mL}$ de soro fisiológico via oral (figura 22) e $50 \mathrm{UI} / \mathrm{kG}$ de insulina encapsulada dispersa em $8 \mathrm{~mL}$ de soro fisiológico via oral (figura 23) foi semelhante aos observados nos animais controle.

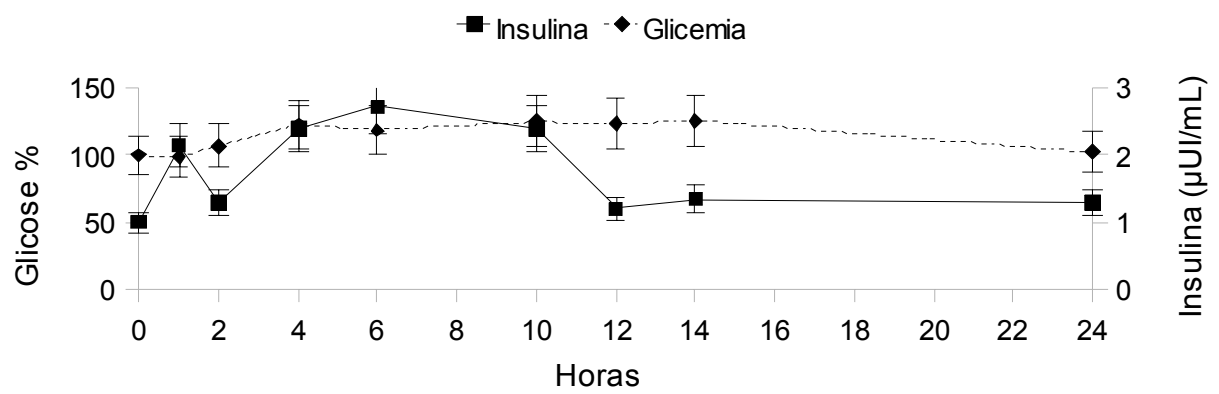

Figura 22: Média da concentração plasmática de insulina e de \% de glicose em função da linha de base, após a administração via ora de $50 \mathrm{Ul} / \mathrm{kg}$ de insulina

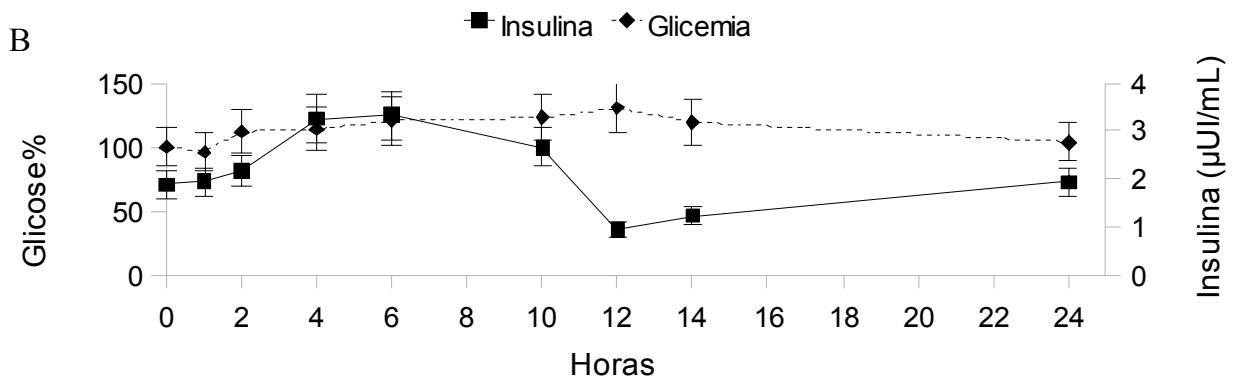

Figura 23: Média da concentração plasmática de insulina e de \% de glicose em função da linha de base, após a administração via ora de $50 \mathrm{Ul} / \mathrm{kg}$ de insulina nanoestruturada.

Nos indivíduos que receberam $50 \mathrm{Ul} / \mathrm{kg}$ de insulina nanoestruturada incorporada em uma matriz lipídica (figura 24) as concentrações de insulina se mantiveram iguais ao grupo controle até as quatorze horas de ensaio. Entre a décima quarta e a vigésima quarta hora houve um incremento na concentração de insulina plasmática $(42,95 \pm 25 \mu \mathrm{Ul} / \mathrm{ml})$. Os valores de glicemia também acompanharam os padrões dos animais controle, contudo na vigésima quarta hora de ensaio, apresentaram uma redução da glicemia para $79,88 \pm 4,3 \%$ da linha de base.

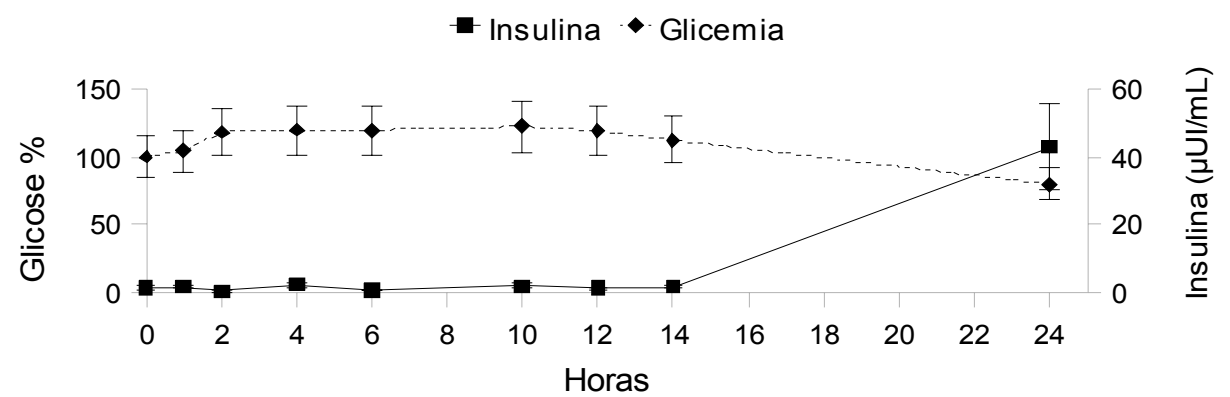

Figura 24: Média da concentração plasmática de insulina e de \% de glicose em função da linha de base, após a administração via ora de $50 \mathrm{Ul} / \mathrm{kg}$ de insulina nanoestruturada incorporada em matriz lipídica. 


\section{DISCUSSÃO}

\subsection{EXPERIMENTO 1}

\subsection{CONDIÇÃO METABÓLICA}

No presente experimento, quando se considerou o efeito de tratamento, durante todo o período de colheita (do D-2 ao D5) os animais do grupo hiperinsulinêmico, apresentaram teor de insulina maior do que os do grupo controle, que, por sua vez, apresentaram teores maiores do que os do grupo diabético (figura 6). Portanto, as condições experimentais pretendidas foram, de fato, alcançadas.

De acordo com Trenkle (1972), nos ruminantes, a insulina tem sua concentração plasmática fortemente influenciada pela fermentação ruminal, atingindo sua concentração máxima no período subsequente ao ápice do processo de fermentação. Baseado nessa informação, para assegurar que o delineamento experimental proposto atingisse o objetivo (i.e. animais hiperinsulinêmicos, hipoinsulinêmicos e controle), optou-se por colher as amostras matinais de sangue, para o doseamento da insulina,evitando-se, com isso, as variações dos teores decorrentes dos diferentes estágios do processo fermentativo. Assim, as amostras de sangue foram colhidas, em média, 15 horas após a última alimentação e, portanto, os teores de insulina obtidos referem-se praticamente aos teores basais. Note-se que os animais diabéticos apresentaram uma redução na capacidade de produção de insulina e não sua completa supressão. Desse modo, durante o período experimental esse grupo sempre apresentou teores de insulina numericamente inferiores aos demais tratamentos. De acordo com Candy et al. (1982) o grau de eficiência da indução do diabetes é dependente da dose da droga diabetogênica e da intensidade de jejum, no momento da indução do diabetes. Por consequência, variações nesses dois fatores interferem na extensão das lesões provocadas às células $\beta$, explicando assim o garu de hipoinsulinemia, encontrado nesse tratamento e a ausência de resposta em dois animais ao processo de diabetogênese.

Os tratamentos controle e hiperinsulinêmicos, por vezes, ao longo do experimento foram semelhantes e isto pode ser explicado não só pelo momento de colheita das amostras, mas também pelo tipo de insulina empregada no experimento.

Ghough (2007) observou que a insulina NPH, aqui utilizada, possui 
depuração completa do plasma de cobaias 12 a 14 horas após sua aplicação. Como a insulina foi administrada em intervalos de 12 horas, o que se mensurou foi a insulina residual da aplicação vespertina do dia precedente. Ao observar a curva insulinêmica apresentada pelos animais que receberam uma formulação $2,5 \mathrm{UI} / \mathrm{kg}$ de insulina cristalina pura (S.C.) no experimento 2 (figura 20), apesar das diferenças experimentais, pode-se ter uma noção do padrão insulinêmico de uma formulação semelhante à utilizada no presente experimento ao longo de 12 horas.

As concentrações plasmáticas de glicose estão intimamente relacionadas às de insulina. Chowdhury e Orkov (1997) relataram que a homeostasia da glicose em ruminantes é dependente da concentração plasmática de insulina. Quando este hormônio é liberado no sistema circulatório, estimula a atividade da proteína transportadora de glicose GLUT 4, presente nos tecidos sensíveis à insulina, que passam a captar maior quantidade de glicose e reduzem sua concentração plasmática (KASANICKI e PILCH, 1990). Assim, os teores glicêmicos do grupo controle $(83,1 \pm 2,1 \mathrm{mg} / \mathrm{dL})$ foram inferiores aos do grupo diabético $(241,2 \pm 9,2 \mathrm{mg} / \mathrm{dL})$ e superiores ao do grupo hiperinsulinêmico $(53,9 \pm 2,7 \mathrm{mg} / \mathrm{dL})$.

A quantidade reduzida de insulina observada no grupo diabético, dificultou a captação e o armazenamento da glicose, obrigando o animal a buscar precursores alternativos de energia, para suprir a demanda celular. De fato, por ser um modulador da homeostasia de carboidratos, baixos níveis de insulina estimulam a atividade da lipase sensível a hormônio e inibem a atividade da ácido graxo sintase, disparando assim, o mecanismo de lipólise e, por consequência, a produção de NEFA (SASAKI, 2003; ADEWUYI et al., 2005). No presente experimento, esta situação ficou evidenciada pela correlação negativa entre insulina e $\operatorname{NEFA}\left(R^{2}=0,42\right.$, $P<0,05)$. Em concordância com este achado, Hayirli (2006) relata que a infusão de insulina exógena em bovinos, promove uma redução quadrática na concentração do NEFA, em função do aumento da insulina administrada.

Ao mensurar os teores plasmáticos de NEFA, durante o experimento, o grupo diabético apresentou valores mais elevados que os demais tratamentos $(\mathrm{P}<0,01)$. Na tabela 3 pode-se observar que, em seguida à indução do diabetes, 0 NEFA se elevou, mantendo-se assim até o término do experimento.

A restrição de glicose, precursor do oxaloacetato, e o simultâneo aumento de acetil-CoA, derivado da degradação do NEFA, no ciclo da $\beta$-oxidação, culminam com o desbalanceamento da proporção de oxaloacetato/acetil-CoA (ADEWUYI et al., 
2005), o que desvia o acetil-CoA para produção de corpos cetônicos e estimula a reesterificação hepática do NEFA (VAN KNEGSEL et al., 2005).

Assim, a baixa capacidade de transporte de triacilgliceróis, aliada a sua intensa produção, culminam com seu acúmulo hepático, desencadeando o aparecimento de um quadro de cetoacidose metabólica, aliada à esteatose hepática, quadro este que, segundo Katoh (2002), é comum em ruminantes, em balanço energético negativo.

De fato, o grupo diabético apresentou sinais clínicos de cetoacidose, bem como, na necrópsia pôde-se verificar aumento de volume e tonalidade amarelada, com evidenciação da lobulação do parênquima hepático, com áreas mais brancacentas sugestivas de regiões ricas em lipídeos. Os achados histológicos são semelhantes aos descritos por Reid e Collins (1980), em vacas leiteiras, com quadro clínico de lipidose hepática. Tais achados consistiram de tumefação celular e extensa vacuolização intracelular dos hepatócitos, próximos à região centrolobular. Com o afastamento da região centrolobular em direção à região periportal, os vacúolos reduzem de tamanho e intensidade. Assim, confirma-se que, acompanhando as demais alterações, todos animais diabéticos também desenvolveram um quadro de esteatose hepática, durante o período experimental, fato que não foi observado nos animais dos demais tratamentos.

\subsubsection{DURAÇÃO DO ESTRO}

As ovelhas diabéticas apresentaram estro mais curto, quando comparadas às demais $(P<0,01)$ (tabela 4$)$.

Nas espécies domésticas, o estradiol é um dos responsáveis pelo aparecimento do comportamento de estro e é intensamente produzido pelo folículo, no período que precede sua ovulação (DULEBA et al., 1997). A redução na duração do estro no grupo diabético, pode ser decorrente de alterações na quantidade de estradiol sintetizado. Entretanto, este fator não foi avaliado, no presente experimento. Os animais diabéticos também produziram menos corpos lúteos que os demais $(P<0,05$ (tabela 5$)$ ), assim, por inferência pode-se supor que estes tenham produzido menores quantidades de folículos préovulatórios e, que somada à capacidade de produção de estradiol, esta seria potencialmente menor.

Dando suporte a esta hipótese, Baril et al. (1995) relataram que, cabras e ovelhas superovuladas tendem a apresentar um tempo de duração de estro maior 
que as receptoras, fato que decorre do maior número de folículos, que conseguiram chegar à fase préovulatória. Por sua vez, Cahill e colaboradores (1981) identificaram uma alta correlação positiva entre o número de folículos maiores que $36 \mathrm{~mm}$ e a concentração plasmática de estradiol, durante o estro de ovelhas Romanov e lle de France.

Contudo, a capacidade esteridogênica dos folículos nos animais diabéticos também pode ter sido comprometida e, com isso, ter contribuído para a redução da duração do estro. Esta hipótese se suporta frente aos vastos relatos na literatura, nos quais os baixos níveis de insulina reduziram a esteroidogênese. Entre os mecanismos envolvidos na diminuição da produção de estradiol, decorrente da redução dos teores de insulina encontram-se: a) redução da captação de colesterol, por reduzir a expressão dos genes que codificam a proteína StAR e os receptores para LDL (SEKAR e VELDUIS, 2004); b) redução da atividade da CYP17 e, por conseqüência, da produção de andrógenos (STEIN et al, 1995; SWAIN et al. 2004) e sua subsequente conversão em estradiol, pela redução da atividade da aromatase (DULEBA et al., 1997; DULEBA et al., 1999).

Adicionalmente, a elevada concentração plasmática de NEFA, também pode ter contribuído para a redução da produção de estrógenos, visto que, pode ocorrer um efeito citotóxico sobre as células da granulosa dos folículos em crescimento (VANHOLDER et al., 2005) e a redução da produção de ésteres de colesterol, pela redução da atividade da lecitina:colesterol aciltransferase (KATOH, 2002).

A ausência de diferença na duração do estro entre os grupos controle e hiperinsulinêmicos se assemelham aos resultados encontrados por Selvaraju et al. (2003), que avaliaram a duração do estro em cabras superovuladas, recebendo $0,2 \mathrm{Ul} / \mathrm{kg}$ de insulina antes e durante o processo de superovulação. Nesse trabalho os animais pré tratados com insulina, apresentaram maior produção de estradiol, em relação ao grupo controle. Todavia não houve diferença estatística entre os tratamentos quanto à duração do estro.

\subsubsection{RESPOSTA OVARIANA}

Como já abordado, não houve diferença estatísticamente significativa entre o número de corpos lúteos produzidos por animais controle e hiperinsulinêmicos. Contudo, ambos produziram mais $C L$ que os animais diabéticos $(P<0,05)$. 
O número de CL formado é dependente da quantidade de folículos que conseguiram atingir a fase preovulatória, portanto, apesar de não mensurado, parece plausível inferir que os animais diabéticos tenham apresentado menor quantidade de folículos preovulatórios. De fato, na literatura estão relatados diversos mecanismos pelos quais a insulina pode favorecer o recrutamento e o crescimento folicular.

O efeito estimulatório sobre o eixo hipotálamo-hipofisário foi descrito em ovinos por Tanaka e colaboradores (2000), que utilizaram carneiros orquiectomizados diabéticos para avaliar o efeito da concentração de insulina no líquido cérebro espinhal, bem como a resposta do LH a este hormônio. Tais autores concluíram que, em ovinos hipoinsulinêmicos, a insulina tem a capacidade de estimular a secreção de LH, atuando como um de seus reguladores e, possivelmente, por estimular a produção de GnRH. Por sua vez, Lee et al. (2008) relataram que a insulina também atua estimulando a expressão da sequência promotora do gene do $\mathrm{GnRH}$ e com isso favorece a produção de gonadotrofinas.

Contudo, o efeito central da insulina pode não ter sido o maior responsável pela redução do número de $\mathrm{CL}$ do grupo diabético, visto que, o processo superovulatório foi efetuado com Pluset $^{\circledR}$, uma formulação comercial que possui quantidades semelhantes de LH e FSH. Adicionalmente à última dose de FSH foi aplicada uma dose de eCG, que possui afinidade simultânea pelos $\mathrm{FSHr}$ e LHr, o que proporciona o suporte gonadotrófico para o crescimento e ovulação dos folículos em desenvolvimento.

Nesse contesto, parece mais provável que a deficiência de insulina tenha apresentado um papel mais importante em escala local, atuando diretamente sobre o folículo.

Em ratos diabéticos, Ballester et al. (2007), fazendo uso de PCR-RT semiquantitativo, identificaram redução na expressão do RNAm, para os receptores de LH e FSH no ovário e extrato uterino, quando comparados ao grupo controle. Se tal condição se repetir em ovelhas, essa seria uma das explicações para a redução da resposta ovulatória, obtida no tratamento superovulatório dos animais diabéticos. Em adição, a insulina possui um conhecido efeito mitogênico e antiapoptótico, já descrito em folículos ovarianos de ovelhas por Scherzer e colaboradores (2009). Tais autores administraram $5 \mathrm{Ul} / \mathrm{kg}$ em dose única a ovelhas na fase folicular e, após 35 horas, dissecaram os folículos e identificaram redução no número de células da 
granulosa em apoptose e aumento no número de células em mitose nos animais suplementados com insulina $(P<0,05)$.

Callaghan e colaboradores (2000), avaliando ovelhas superovuladas alimentadas com dietas de $50 \%$ da mantença, observaram que estes animais apresentaram menor produção de folículos quando comparados aos controles. Esses autores concluíram que, animais em baixo plano nutricional, respondem deficitariamente ao processo de superovulação, em função do pequeno número de folículos de 2 a $3 \mathrm{~mm}$. Como previamente abordado, o diabetes mimetiza uma condição de restrição alimentar, que pode ser responsável pelos resultados obtidos no presente experimento.

Por sua vez, Cox et al. (1994) avaliaram a influência da insulina em marrãs suínas diabéticas. Ao interromper as aplicações de insulina, foi detectada redução no número de folículos e aumento da sua taxa de atresia, falha de ovulação e elevação da IGF I periférica. Os autores atribuíram tais constatações ao déficit de insulina e concluíram que o processo de atresia folicular é provavelmente independente das concentrações plasmáticas de gonadotrofinas. Nos resultados apresentados por Cox et al., apesar de ser em espécie distinta à do presente experimento, os comportamentos em relação aos achados clínicos e ao número de folículos foram semelhantes aos do presente experimento, inclusive com o aparecimento de estruturas císticas parcialmente luteinizadas. Vanholder et al. (2006) atribuem a formação de cistos anovulatórios de vacas de leite, em balanço energético negativo, a uma falha na produção de um pico preovulatório de LH e/ou à redução de seus receptores no folículo. Assim, frente às evidências já apresentadas, o mecanismo mais provável, pela formação das estruturas císticas, deve estar associado ao déficit de receptores ou à incapacidade de diferenciação e proliferação celular.

De certa forma, a redução do crescimento folicular, ou mesmo a formação das estruturas císticas não se restringem exclusivamente ao déficit de insulina. $A$ elevação do NEFA exerce um efeito citotóxico que culmina em apoptose e redução da proliferação das células da granulosa. Esse fato foi bem descrito por Vanholder et al. (2005) ao avaliarem a adição de $150 \mu \mathrm{M} / \mathrm{mL}$ de NEFA ao cultivo de células da granulosa de bovinos. O efeito negativo do NEFA sobre o crescimento folicular também deve ter se manifestado, visto que, houve uma correlação negativa entre o número de $C L$ e a concentração plasmática de $\operatorname{NEFA}\left(R^{2}=0,6, P<0,01\right)$.

Ademais, a queda da insulina e a elevação das concentrações de NEFA 
induziram ao desenvolvimento de um quadro de esteatose hepática nos animais diabéticos. Nessa condição, as funções hepáticas podem ficar comprometidas, reduzindo a produção de IGF-I, dificultando ainda mais o crescimento folicular ou a formação do CL (BOBE et al., 2004). Apesar de não terem sido medidos os valores da IGF-I nesse experimento, é provável que seus valores nos animais diabéticos também estivessem diminuídos.

Na literatura consultada, os relatos de suplementação de insulina com intuito de melhorar os índices reprodutivos em ovinos são raros. Todavia, Silva-neto e colaboradores (2008) administraram 0,25 UI/kg de insulina a ovelhas na fase folicular e não observaram diferenças de tamanho e número de folículos entre os tratamentos. A ausência de diferenças foi atribuída ao pequeno número amostral.

Contudo, Almeida e colaboradores (2001) obtiveram aumento no número de CL de porcas submetidas ao tratamento de 0,4 Ul/kg de insulina por 7 dias. Sarath et al. (2008) observaram aumento na população de folículos com 3 a $4 \mathrm{~mm}$ em cabras superovuladas, com tratamento prévio de cinco dias de insulina, na dose de $0,2 \mathrm{Ul} / \mathrm{kg}$. Em ambos os casos, os resultados foram atribuídos aos estímulos mitogênico e antiapoptótico da insulina, culminando assim em redução da atresia folicular .

Selvaraju e colaboradores (2003) superovularam cabras suplementadas diariamente com $0,2 \mathrm{UI} / \mathrm{kg}$ de insulina e identificaram uma elevação no número de folículos recrutados; entretanto isto não foi suficiente para aumentar o número de CL em relação ao grupo controle Tais autores atribuíram as falhas de ovulação à deficiência de receptores de LH nos folículos, ou mesmo à imaturidade de alguns folículos. Apesar da espécie ser diferente, os resultados de Selvaraju et al. se assemelham aos encontrados no presente experimento, inclusive com a presença de folículos não ovulados, o que potencialmente explicaria a ausência de diferença entre os tratamentos hiperinsulinêmico e controle. Uma possível explicação para tal falha de ovulação, além das já abordadas por Selvaraju et al. (2003), seria uma proliferação desordenada das células da granulosa, fato este frequente em mulheres com ovário policístico (ESHRE Capri Workshop Group, 2006). Dando suporte à esta hipótese, Christman et al. (2000), induziram um quadro de hiperinsulinemia associado à refratariedade da insulina em ovelhas e, com isso, obtiveram sucesso na indução de cistos foliculares.

O menor número total de embriões $(P<0,05)$ e de estruturas $(P<0,01)$ 
colhidos no grupo diabético, em relação aos animais controle e hiperinsulinêmicos, pode ser explicado pelos mesmos motivos que a redução no número de CL, visto que essas variáveis são dependentes da quantidade de folículos ovulados.

O IQE foi desenvolvido por Sales et al. (2008) para avaliar o efeito de um tratamento sobre a qualidade embrionária, assim, quanto mais próximo de 1 estiver, melhor o efeito do tratamento sobre a qualidade embrionária.

No presente experimento, os animais diabéticos apresentaram IQE maior do que os dos demais tratamentos $(P<0,01)$, indicando a produção de embriões de baixa qualidade. Em contrapartida, os tratamentos controle e hiperinsulinêmicos foram semelhantes entre si.

Estudos in vitro com embriões, realizados por Augustin et al. (2003), nos quais foram avaliados meios de cultivo celular com e sem insulina, foram indicativos de que este hormônio apresentou um efeito antiapoptático, melhorando a qualidade embrionária, a taxa de clivagem, aumentando o número de blastocistos e o seu número de células. De acordo com Harvey e Keye (1990), embriões de ratas superovuladas, colhidos no segundo dia e cultivados em presença de insulina, apresentaram $9 \%$ a mais de células que o grupo controle e maior quantidade de blastocistos.

De fato, os resultados observados in vitro parecem ser reprodutíveis in vivo. Almeida e colaboradores (2001) recolheram maior número de blastocistos, e com melhor qualidade em marrãs suínas, submetidas a 7 doses consecutivas de 0,4 $\mathrm{UI} / \mathrm{kg}$ de insulina. Cabras superovuladas, em presença de 0,2 UI/kg de insulina, durante três dias após o estro, também apresentaram melhoria na qualidade embrionária, quando comparadas ao grupo controle (Souza et al., 2009). Por sua vez, Mann e colaboradores (2003) observaram que bovinos, recebendo dietas hiperinsulinêmicas, apresentaram maior número de embriões, com mais de $10 \mathrm{~cm}$ e com maior capacidade de produção de interferon TAU.

No presente estudo, não foram observadas diferenças no IQE entre tratamento controle e hiperinsulinêmico.

Porém, quando avaliado o número de mórulas e blastocistos produzidos pelos animais de ambos tratamentos, nota-se que os animais hiperinsulinêmicos apresentaram maior quantidade de blastocistos em relação à de mórulas, comportamento que foi oposto ao do grupo controle. Pode-se inferir que a insulina favoreceu o desenvolvimento embrionário, o que é compatível com seu efeito 
inibidor da apoptose e estimulador da mitose. Além disto,observou-se elevado número de células apoptóticas nos CL dos animais diabéticos.

No caso dos animais diabéticos, menor IQE pode estar relacionado a baixos níveis de insulina, o que pode ter aumentado a taxa de apoptose ou reduzido a mitose das células embrionárias. Ademais, a deficiência de insulina também pode ter reduzido a produção de histotrófos, pela redução da adenogênese das glândulas endometriais, ou a redução do estímulo à atividade da bomba $\mathrm{Na-K}$ Atpase (DEACHAPUNYA et al, 1999; GRAY et al., 2001).

Os elevados teores de NEFA no plasma também contribuem com aumento das falhas reprodutivas (BUTLER, 2003) e podem causar queda de qualidade e morte embrionária (LEROY et al., 2008). De fato,no presente experimento, verificouse uma correlação positiva entre IQE e $\operatorname{NEFA}\left(R^{2}=0,65, P<0,01\right)$.

$\mathrm{Na}$ literatura, não foram encontradas descrições de índices de qualidade do CL em ovinos. Baril et al. (1995) mencionaram que a qualidade do CL é de grande importância no processo de transferência de embriões de pequenos ruminantes, sem contudo, elucidar quais características devem ser avaliadas. Por sua vez, Guido e colaboradores (2003) classificaram CL de receptoras caprinas, em função do tamanho e concluíram que o tamanho do CL exerce influência na taxa de prenhez.

Apesar de não ter sido detectada diferença estatística entre o IQCL do grupo controle e o do hiperinsulinêmico, o segundo mostrou-se numericamente inferior, enquanto o grupo diabético obteve valores mais elevados, diferindo de ambos $(p<0,01)$.

Suguna e colaboradores (2009) avaliaram, por ultrasonografia, o diâmetro médio de CL de cabras suplementadas com 0,2Ul/kg de insulina, durante os três dias precedentes ao estro e nos dois primeiros terços de gestação e não encontraram diferenças com relação ao controle. Contudo, Cox e colaboradores (1994), observaram redução de tamanho do CL de marrãs suínas diabéticas, em relação ao dos CL das marrãs do grupo controle. Esses achados,se assemelham aos encontrados no presente experimento e podem ser explicados pela redução do efeito antiapoptótico e mitogênico que a insulina possui, mediado pela MAP quinase (SASAKI, 2003). Por sua vez, nesses animais, o NEFA por sua ação citotóxica (EMERY, et al., 1992), também pode ter contribuído para a redução da qualidade dos CL, uma vez que os teores de NEFA e IQCL estiveram correlacionados positivamente $\left(R^{2}=0,46, P<0,01\right)$. 
O IQCL correlacionou-se negativamente com a produção de progesterona $\left(R^{2}=0,47, P<0,05\right)$, sugerindo que esse índice apresenta potencial aplicação para avaliação de CL em programas de transferência de embriões.

\subsubsection{AVALIAÇÃO HISTOPATOLÓGICA}

Os valores encontrados para proporção de tecido luteínico (85,01\%), tecido conjuntivo e fibroblastos (13,9\%) e células endoteliais e pericitos (1,09\%) se encontram próximos aos relatados por Rodgers et al. (1984), em CL de ovelhas, cujas porcentagens foram, respectivamente, 79,58, 17,69 e 2,73\%. O diâmetro maior das LLC (29 a $35 \mu \mathrm{m})$ e SLC (14 a $17 \mu \mathrm{m})$ encontrados, neste experimento, foram semelhantes aos relatados por Farin et al. (1986) ( 26 a $31 \mu \mathrm{m}$ e 14 a $18 \mu \mathrm{m}$, respectivamente para LLC e SLC).

Nas avaliações citométricas, as LLC do grupo diabético apresentaram hipotrofia celular, com marcada redução de sua área, quando comparadas às dos demais grupos $(P<0,05)$, quadro sugestivo de uma redução da atividade metabólica das células luteínicas, que pode ser devida à hipoinsulinemia.

Esta hipótese é suportada pelos achados de Rabiee e colaboradores (1997), que ao canularem a veia e a artéria ovarianas de ovelhas, mediram algumas substâncias que poderiam servir como fonte de energia para o CL. Concluíram que a glicose é a principal fonte de energia ovariana. Assim, a deficiência de insulina pode diminuir a disponibilidade de glicose para o $\mathrm{CL}$

Adicionalmente, Farin e colaboradores (1986), observaram que, tanto as LLC, quanto as SLC de ovelhas, no décimo sexto dia do ciclo estral, quando se inicia o processo de luteólise tiveram o volume celular e a capacidade de produção de progesterona reduzidos. A observação de redução da atividade metabólica nas LLC das ovelhas diabéticas, ganha apoio com os achados de vacuolização intracelular. Segundo Lunn e colaboradores (2002) essa vacuolização é decorrente do acúmulo de lipídeos nas LLC de CL em regressão em mulheres.

De acordo com Hild-Petito et al. (1987), em ovelhas superovuladas, as LLC são responsáveis por aproximadamente $94 \%$ da progesterona produzida pelo $\mathrm{CL}$, enquanto que o restante fica a cargo das SLC. Assim, as alterações histológicas identificadas podem ter comprometido a capacidade esteroidogênica dos $C L$ dos animais diabéticos.

Neste mesmo tratamento também foi identificado um aumento no número de 
células apoptóticas por campo em comparação aos demais $(P<0,05)$. Thwaites e Edey (2005), identificaram que ovelhas submetidas a uma restrição alimentar severa, de sete dias, apresentaram elevação do número de células luteínicas com sinais de apoptose. Tais autores concluíram que essas alterações culminaram em disfunção da esteroidogênese, luteólise e possivelmente aumento da morte embrionária. De fato, o quadro de diabetes assemelha-se muito a uma situação de restrição alimentar severa. Corroborando com a hipótese de luteólise prematura nos animais diabéticos, foi identificada elevação no grau de desorganização tecidual nos CL. Segundo Lunn et al. (2002), durante a luteólise, ocorre uma desorganização tecidual no CL, que dificulta a identificação dos tipos celulares.

O número de células apoptóticas correlacionou-se negativamente com a área de tecido luteínico $\left(R^{2}=0,63 ; p<0,05\right)$, com a produção de progesterona $\left(R^{2}=0,60 ; p<0,05\right)$ e com o diâmetro maior das SLC $\left(R^{2}=0,61 ; p<0,05\right)$. Em contrapartida, as células apoptóticas correlacionaram-se positivamente com a área de tecido conjuntivo e fibroblastos $\left(R^{2}=0,71 ; p<0,01\right)$ e a área de tecido conjuntivo e fibroblastos foi negativamente correlacionada com a produção de progesterona $\left(R^{2}=0,64 ; p<0,05\right)$. Tais correlações são sugestivas de um quadro de luteólise Nos animais diabéticos, a área e o diâmetro maior das LLC se correlacionaram com a proporção de células endoteliais e pericitos (respectivamente $R^{2}=0,88(p<0,05)$ e $R^{2}=0,99(p<0,01)$. Essas correlações evidenciam que as LLC, de menor diâmetro, se encontram em um ambiente menos irrigado e possivelmente com maior grau de hipóxia.

Os achados macroscópicos são complementares às alterações celulares encontradas, em que o tratamento que possui IQCL mais elevado, também apresenta desorganização tecidual, elevada presença de células apoptóticas, hipotrofia e vacuolização das LLC. Estes sinais são indícios citológicos de início de luteólise. Aliado a esse fato, houve correlação negativa entre a produção de progesterona e IQCL, que também dá suporte a esta observação, uma vez que, o início da luteólise é marcado pela redução do volume celular e da produção de progesterona (FARIN et al., 1986), pelo aumento da taxa de apoptose e redução do fluxo sanguíneo (BERTAN et al., 2006). 


\subsubsection{PRODUÇÃO DE PROGESTERONA}

As dosagens de progesterona foram realizadas todos os dias entre a remoção do pessário vaginal e o dia em que precedeu a colheita embrionária, com o objetivo de acompanhar o desenvolvimento da capacidade esteroidogênica do CL.

As concentrações de progesterona medidas no D-2 foram estatisticamente diferentes, segundo tratamento, mas estas diferenças não têm significado biológico e nem podem ser atribuídas aos tratamentos, pois podem ser apenas devidas à fase do ciclo estral em que se encontravam os animais, no dia da colocação dos pessários. Do D-1 ao D1, as diferenças não foram significativas. Entretanto, do D2 ao D5 os teores de progesterona dos animais do grupo diabético foram menores do que os dos animais dos grupos controle e hiperinsulinêmicos (tabela 7 e figura 12).

No experimento conduzido por Spicer (2005), realizado in vitro, com cultivo de células da teça, em presença de estrógeno, LH e insulina foi evidenciado que a adição de insulina ao meio de cultivo aumentou em até três vezes e meia a produção de progesterona em relação ao controle. Mao et al. (2001) observaram que células luteínicas do ciclo subsequente de marrãs tratadas com 0,4 Ul/kg entre 0 oitavo e décimo quinto dias do ciclo estral, quando cultivadas in vitro, produziram mais progesterona que as células testemunha. Este efeito foi atribuído à maior produção de RNAm da proteína StAR e do citocromo $P 450_{s c c}$, o que levou tais autores a concluírem que o aumento da insulina na fase de maturação folicular interfere na função luteínica subsequente.

Alguns experimentos in vivo reproduzem o efeito estimulador da insulina sobre a produção de progesterona. Selvaraju (2003) superovularam cabras previamente tratadas com de 0,2 UI/kg de insulina. Apesar do número de CL ter sido semelhante nos dois tratamentos, os animais apresentaram produção de progesterona estatisticamente maior. Tais autores atribuíram o fato ao estímulo esteroidogênico da insulina.

Suguna e colaboradores (2009) observaram que a administração exógena de insulina foi capaz de aumentar a produção de progesterona, nos primeiros sessenta dias de gestação de cabras, contudo, no período subsequente, não houve diferença entre os tratamentos. Esses resultados foram obtidos com a suplementação de $0,2 \mathrm{UI} / \mathrm{kg}$ de insulina, durante os três dias precedentes ao estro e nos dois terços iniciais de gestação. Tais autores atribuíram esses resultados a um 
aumento da taxa de ovulação e da capacidade esteroidogênica do CL.

No presente experimento, a suplementação de insulina não se mostrou eficiente em aumentar a produção de progesterona. A divergência com os resultados da literatura provavelmente pode ser atribuída à dose de insulina utilizada, que foi cinco vezes superior às doses utilizadas em experimentos semelhantes. Nas concentrações utilizadas, durante o ápice da ação da insulina, alguns animais manifestaram sinais clínicos de hipoglicemia, com valores inferiores à $20 \mathrm{mg} / \mathrm{dL}$. Assim, a hipoglicemia pode ter comprometido a máxima produção de progesterona e, com isso, nivelado os resultados nos dois tratamentos.

Contudo, nos animais diabéticos a deficiência de insulina influenciou negativamente a produção de progesterona, acompanhando os achados de literatura. Isso ficou evidenciado nesse tratamento, pela correlação positiva entre os dois hormônios $\left(R^{2}=0,88, P<0,01\right)$. Possivelmente, como já discutido, a insulina pode ter reduzido a atividade dos enzimas envolvidos na esteroidogênese.

Todavia, o número de $C L\left(R^{2}=0,53, P<0,01\right)$, bem como sua qualidade $\left(R^{2}=-\right.$ $0,47, P<0,05)$, e a concentração de NEFA $\left(R^{2}=-0,44, P<0,05\right)$ foram correlacionados nos tratamentos com a produção de progesterona.

Por fim, o modelo de diabetes induzida em ovelhas conduz a um quadro de hipoinsulinemia, que por sua vez desencadeia uma série de alterações metabólicas. Por esta razão as alterações morfológicas e funcionais observadas nem sempre podem ser diretamente atribuídas à deficiência de insulina per si, mas podem ser decorrentes de um novo estágio metabólico, que inclui abundância de glicose, porém o acesso a ela fica preferencialmente restrito aos tecidos que independem de insulina. Além disto, esta síndrome envolve o catabolismo de lipídeos e proteínas, com aumento de metabólitos como NEFA, corpos cetônicos e uréia, com seus efeitos diretos e indiretos sobre a reprodução. Este modelo pode ser útil para estudos do impacto do balanço energético negativo, uma vez que mimetiza uma situação de restrição alimentar. 


\subsection{EXPERIMENTO 2}

\subsubsection{CARACTERIZAÇÃO FISICOQUÍMICA}

Os sistemas de encapsulamento nanométrico podem ser utilizados para melhorar, ou modificar as características farmacológicas de vários tipos de drogas, inclusive de proteínas. Em medicina veterinária apresentam grande potencial de aplicação para proteção de hormônios reprodutivos (e.g. FSH, eCG) e antígenos vacinais. A escolha do ovino diabetes induzido, como modelo animal, para estudo de permeação de mucosa, foi fruto da experiência adquirida junto ao primeiro experimento e pela facilidade de mensurar a manutenção da atividade biológica da insulina nanoestruturada, inferida aqui pela redução da glicemia. Seguindo esta linha, no presente experimento avaliou-se a utilização de um sistema nanométrico, obtido com o auxílio do polímero biodegradável quitosana, para liberação sustentada e permeação de mucosa da insulina em ovinos.

No presente trabalho, foram confeccionadas nanopartículas, cuja maioria se encontrava com diâmetro inferior a $100 \mathrm{~nm}$, confirmado tanto por espalhamento de luz dinâmico, quanto por microscopia eletrônica de varredura.

$\mathrm{Em} \mathrm{pH} \mathrm{5,5,} \mathrm{a} \mathrm{quitosana} \mathrm{se} \mathrm{encontra} \mathrm{predominantemente} \mathrm{protonada,}$ enquanto que o TPP, em pH 9, fica desprovido de cargas positivas. Por sua vez, a insulina que possui ponto isoelétrico de 5,1 , ao ingressar no meio contendo quitosana, fica negativamente carregada e, durante a confecção da nanopartícula, a insulina acaba se incorporando pela interação das cargas opostas. Aparentemente, a interação entre as cargas positivas da quitosana e as negativas do TPP, é a principal força física que rege a formação das nanopartículas e também a incorporação da insulina.

De acordo com Aranaz et al. (2009), o grau de desacetilação, o peso molecular e a relação e/ou concentração quitosana/reticulante são os principais fatores que afetam o tamanho final da partícula. Calvo e colaboradores (1997) avaliaram o aumento da quantidade do TPP (20 e 40\%), em quantidades fixas de quitosana de baixo peso molecular, durante a produção de nanopartícula. Foram produzidas partículas com tamanho médio variando entre 263 e $745 \mathrm{~nm}$ e tais autores concluíram que o aumento da concentração do agente reticulante resulta em aumento do tamanho da partícula. 
Quando comparado a este experimento, no qual se utilizou uma relação de $28,7 \%$ de TPP/quitosana de baixo peso molecular (w/w) e se produziram partículas menores, a diferença encontrada pode ser atribuída ao elevado grau de desacetilação da quitosana utilizada. Maiores quantidades de grupamentos aminos favorecem a rápida e intensa reticulação da partícula e, com isso, a diminuição do tamanho.

Todavia, em comunicações prévias, também foi observado que a incorporação de substâncias às nanopartículas eleva o seu tamanho e o índice de polidispersão (IPD). Chen et al. (2007) produziram nanopartículas de quitosana, por interação eletrostática entre cargas opostas (geleificação ionotrópica), porém utilizando o sulfato de dextran como agente reticulante. A incorporação de BSA culminou em aumento do tamanho médio das partículas de 350 (brancas) para 478 (com BSA) nm e do IPD que passou de 0,55 para 0,64.

O mesmo comportamento da nanopartícula também foi observado por Pan et al. (2002) e por Fernandez-Urrusuno et al. (1999) ao encapsularem insulina em nanopartículas de quitosana/TPP, nas quais a quitosana possuía respectivamente $88,9 \%$ e $70 \%$ de desacetilação. Tais autores produziram nanopartículas brancas com $265 \mathrm{~nm}($ IPD $=0,33)$ e $311 \mathrm{~nm}($ IPD=0,48) e nanopartículas com insulina com $387 \mathrm{~nm}$ $(\mathrm{IPD}=0,4)$ e $352 \mathrm{~nm}$ (IPD=0,46). As partículas produzidas no presente estudo foram significativamente menores e a explicação para isso parece mesmo ser pelo grau de desacetilação da quitosana utilizada, já que as demais variáveis (peso molecular e relação/concentração de reticulante) foram semelhantes entre os experimentos.

A incorporação da insulina à nanopartícula é o fator responsável pelo aumento do IPD, para o deslocamento à direita e pelo alargamento da base da curva de distribuição de tamanho (figura $X$ ) das nanopartículas que carrearam a insulina, quando comparadas às brancas nesse estudo.

O potencial Zeta é uma medida utilizada para avaliar a carga elétrica superficial de uma partícula e seus valores são de suma importância para prever a estabilidade física de uma formulação (Soppimath et al., 2002).

Sarmento e colaboradores (2006) compararam a influência de diferentes concentrações e relações de quitosana/dextran, no processo de confecção de nanopartículas em pH constante. A conclusão foi que o aumento na concentração dos precursores da nanopartícula, desde que proporcionais, não interfere no potencial Zeta. Entretanto, mudanças nas proporções de seus constituintes podem 
alterar a carga elétrica superficial da partícula.

Em estudo semelhante, Lin et al. (2007) avaliaram a relação ácido poliglutâmico/quitosana, no processo de formação de nanopartículas, porém, também levaram em consideração a variação de $\mathrm{pH}$ do meio em que as partículas se encontravam. A observação final foi que o aumento da quantidade de quitosana, bem como a redução do pH da solução conduzem à protonação das partículas.

Chen et al. (2007), por sua vez, levaram em consideração o efeito da proteína encapsulada nas características físico-químicas da partícula e, para tanto, utilizaram como modelo a albumina sérica bovina (BSA). Nesse trabalho, os autores não identificaram influência da incorporação da BSA no potencial Zeta de partículas formadas a partir de diferentes concentrações de quitosana/dextran. Entretanto, Sarmento et al. (2006) ao encapsular insulina em nanopartículas semelhantes e em $\mathrm{pH}$ constante, observaram um aumento significativo do potencial zeta, de $-16,4$ para $-10,5 \mathrm{mV}$.

No presente experimento, ao término da confecção, obtiveram-se nanopartículas, com potencial Zeta superior ao módulo de $30 \mathrm{mV}$, indicando elevada estabilidade do sistema nanométrico em suspensão e grande mucoadesividade. Nestas condições, as nanopartículas, altamente carregadas com carga positiva, se repelem eletrostaticamente e, com isso, não se agregam, o que impede a formação de precipitados. De acordo com relatos da literatura, provavelmente a relação chitosana/TPP utilizada e o pH final da solução, permitiram que vários grupamentos amino do biopolímero permanecessem protonados, mantendo o caráter catiônico das nanopartículas. Ademais, a incorporação da insulina à nanopartícula promoveu uma suave redução no potencial Zeta $(+40,5 \mathrm{mV}$ versus $+37 \mathrm{mV})$.

Comparando estes resultados aos obtidos por Sarmento et al. (2006), a diferença pode ser atribuída à maior eficiência de encapsulamento $(87,3 \%)$, superior à obtida no presente estudo $(38,3 \% \pm 2,8)$. A menor quantidade de insulina presente na partícula, certamente causou um discreto impacto no balanço das cargas dos precursores da partícula, visto que nanopartículas brancas e contendo insulina foram produzidas nas mesmas condições.

A eficiência de encapsulamento da insulina, no presente estudo, também foi menor que a descrita por Pan et al. (2002), que conseguiram índices variando entre $66 \%$ em nanopartículas com $265 \mathrm{~nm}$ e $88 \%$ nas com $387 \mathrm{~nm}$. Fernandez-Urrusuno et al. (1999) apresentaram resultados variando entre 96\%, para nanopartículas de 317 
$\mathrm{nm}$ e $92 \%$ quando estas atingiram $352 \mathrm{~nm}$.

Durante a confecção das nanopartículas, parte da insulina pode ficar entremeada nas cadeias da quitosana, aprisionadas em seu interior. A menor eficiência de encapsulamento pode ser atribuída, em parte, ao menor tamanho da partícula que, durante o sua formação, permitiu um maior escape da insulina, provavelmente fruto do aumento da superfície de contato. Todavia, este não é o único fator envolvido, variações de peso molecular e grau de desaceticlação da quitosana, a relação reticulante/quitosana e a condição de confecção das partículas também modificam a eficiência de encapsulamento, explicando assim, as diferenças encontradas na literatura.

Análises espectrais no infravermelho podem ser utilizadas para investigar a interação entre substâncias. Boonsongrit et al. (2008) avaliaram os espectros de micropartículas de quitosana/TPP, encapsulando concentrações de insulina que variaram de 1 a $5 \mathrm{mg} / \mathrm{mL}$. Nas concentrações pôde-se detectar a interação entre insulina e quitosana pela mudança de três para duas bandas no número de ondas entre $1400-1500 \mathrm{~cm}^{-1}$.

$\mathrm{Na}$ avaliação do espectro de infravermelho deste experimento, não foi detectada tal alteração nas nanopartículas, possivelmente porque a concentração de insulina utilizada $(0,0643 \mathrm{mg} / \mathrm{mL}$ na concentração final da formulação) foi expressivamente menor que as utilizadas por Boosongrit e colaboradores. A baixa concentração de insulina pode ter resultado em fraca força vibracional, característica dessa interação, furtando à resolução do equipamento empregado na análise. Entretanto, identificou-se um alargamento na base dos picos, entre os comprimentos 1284 e $1034 \mathrm{~cm}^{-1}$ nas nanopartículas, referentes a ligações $C=0$, típicas de TPP que foi incorporado à nanopartícula. Por conseqüência, essa região do espectro pode ser utilizada para monitorar a formação da nanopartícula.

\subsubsection{ENSAIOS DE LIBERAÇÃO}

No cromatograma do padrão de liberação in vitro, assim como nos sobrenadantes da separação das nanopartículas, só foi encontrado um único pico, no tempo de retenção da insulina. Tal fato indica que o processo de produção e estocagem das nanopartículas não promoveu a degradação do hormônio em questão.

Durante o ensaio de liberação in vitro, as nanopartículas puras 
apresentaram um pico inicial de liberação, atingindo cerca de $80 \%$ de liberação nas primeiras 2 horas de ensaio, sugerindo que parte da insulina presente na nanopartícula se encontrava adsorvida à superfície. Nas vinte e duas horas restantes, ocorreu uma suave liberação de aproximadamente $10 \%$ de insulina. Essa segunda fase de liberação, bem mais lenta que a primeira, provavelmente deriva da insulina entremeada às cadeias de quitosana.

Quando as nanopartícusas foram incorporadas à matriz lipídica, ocorreu uma liberação inicial de $11 \%$, com discreta liberação no período restante. Nessa condição, o pico inicial de liberação, provavelmente, tem origem nas partículas que estão na interface lipídeo/meio de liberação. Assim, a matriz lipídica claramente isolou parte das nanopartículas do meio aquoso, impedindo sua liberação.

Fernandez Urusuno et al. (1999) avaliaram a velocidade de liberação da insulina encapsulada, em nanopartículas de quitosana/TPP, sobre diferentes condições de $\mathrm{pH}$. Em pH 7,4, foi observada uma liberação inicial de quase a totalidade da insulina encapsulada, na primeira meia hora de ensaio. À medida em que $\mathrm{o} \mathrm{pH}$ do meio se aproximou do ponto isoelétrico da insulina, a velocidade de liberação foi reduzida. Porém, em água Milli-Q, os autores encontraram uma liberação máxima de $30 \%$, nas primeiras duas horas de ensaio. Tais autores chegaram à conclusão de que a interação da insulina com a nanopartícula de quitosana, bem como seu padrão de liberação, são regidos pela dissociação iônica do complexo insulina quitosana. Pan et al. (2002) também avaliaram o padrão de liberação da insulina, em função do $\mathrm{pH}$, e chegaram a conclusões semelhantes. Todavia, em pH 7,4, as nanopartículas apresentaram um pico de liberação de 84\%, nas primeiras duas horas de ensaio, liberando mais $4 \%$ nas três horas subsequentes de ensaio.

Por outro lado, Bayat e colaboradores (2008) obtiveram liberação máxima com cinco horas de ensaio. Esses autores estudaram o padrão de liberação de nanopartículas de insulina, confeccionadas com diferentes tipos de quitosana, em $\mathrm{pH}$ 7,4 e concluíram que seu peso molecular pode influenciar no padrão de liberação e que a velocidade de liberação inicial é altamente dependente da adequada complexação da insulina à cadeia polimérica, a qual permite a formação de complexos pouco solúveis em água.

Em verdade, os mecanismos que regem a formação das nanonopartículas não foram uniformes para todos os experimentos, assim, a localização e a interação 
da insulina com a nanopartícula certamente variou entre os experimentos citados, sendo essas as principais diferenças no padrão de liberação encontrado na literatura. Dentre os artigos, o padrão de liberação obtido por Pan et al. (2002) foi o que mais se assemelhou ao do presente experimento e isso se deve à semelhança entre as condições de preparo das nanopartículas, diferindo, prioritariamente, nas maiores partículas obtidas por esses autores.

Era de se esperar que nanopartículas menores, apresentassem um uma velocidade de liberação mais rápida, contudo, durante o processo de liofilização, pode ter ocorrido uma agregação das nanopartículas que, durante o processamento são forçosamente aproximadas. Por sua vez, a agregação das nanopartículas aumenta seu raio hidrodinâmico e estas assumem um comportamento de liberação intermediário entre partículas maiores e menores. Entretanto o efeito de uma maior interação entre as cadeias do polímero e a insulina não pode ser desprezada na diferenciação entre os padrões de liberação dos experimentos, visto que isso também retardaria a liberação da insulina.

Os ensaios de liberação in vivo deste experimento foram acompanhados das mensurações de glicose, descritas como redução da glicemia, em relação à linha de base em carneiros diabetes induzidos.

Não foram encontrados na literatura experimentos que fizeram uso de sistemas nanoestruturados, para liberação sustentada de proteínas em ruminantes, ou mesmo que tentaram avaliar a permeação da mucosa gastrointestinal com proteínas.

Durante a realização do experimento, os tratamentos controle, nanopartícula branca (S.C.), insulina pura $50 \mathrm{UI} / \mathrm{kg}$ (V.O.), $50 \mathrm{UI} / \mathrm{kg}$ de insulina nanoestruturada (V.O.) e 50Ul/kg de insulina nanoestruturada incorporada à matriz lipídica, não apresentaram mudanças na concentração plasmática da insulina ao longo das primeiras quatorze horas de ensaio. Coincidente com este período, os mesmos tratamentos também apresentaram um aumento médio de $20 \%$ nos valores da linha de base da glicemia, o que se justifica pelo maior aporte de precursores da glicose (principalmente o propionato) que se originaram durante a fermentação ruminal da ingesta.

Ambos os tratamentos que receberam 2,5 Ul/kg de insulina (S.C.), seja na forma pura ou nanoencapsulada, apresentaram uma rápida elevação da concentração plasmática de insulina, embora a insulina nanoencapsulada tenha 
apresentado um pico mais discreto. Após esse pico, nos dois tratamentos, houve redução da concentração de insulina, porém em cinética diferente, como pode ser observado pela análise das figuras 20 e 21. A comparação visual, porém não estatística, ressalta que no tempo de 14 horas de ensaio, houve uma inversão nas concentrações de insulina entre os tratamentos, com os animais que receberam a insulina nanoencasulada apresentando $15.6 \pm 1,5 \mu \mathrm{Ul} / \mathrm{mL}$ e os que receberam insulina pura $8.7 \pm 1,9 \mu \mathrm{UI} / \mathrm{mL}$.

Nesses dois tratamentos, a glicemia apresentou comportamento inverso, com queda inicial e posterior elevação ao longo do tempo, sem contudo ocorrer inversão da numérica nos percentis da linha de base da glicemia.

Estes resultados, analisados em conjunto, são sugestivos de que houve um comportamento de liberação sustentada da insulina, todavia a liberação deste hormônio não foi suficiente para alcançar o nível terapêutico. Ao se encapsular um princípio ativo, ele pode ficar entremeado às cadeias poliméricas e apresentar redução da toxicidade e da biodisponibilidade (COUVREUR et al., 2002). Essa hipótese pode ser aventada, uma vez que, no grupo que recebeu insulina pura, um animal apresentou sinais clínicos de hipoglicemia e quando mensurada se encontrava em $18 \mathrm{mg} / \mathrm{dL}$.

Reis et al. (2007) observaram o padrão de liberação de insulina nanoencapsulada via subcutânea em ratos. Ao aplicar 4 UI/kg de insulina pura ou nanoestruturada, os autores detectaram queda na glicemia semelhante entre os tratamentos e, por inferência, efeito de liberação sustentada da insulina, que foi atribuída à retenção do hormônio entre as cadeias das nanopartículas. Ao comparar os resultados dos dois experimentos, observa-se que Reis e colaboradores utilizaram uma dose mais elevada de insulina e, talvez por isso, tenham atingido o nível terapêutico.

Outra abordagem bastante encontrada na literatura é a permeação da mucosa gastrintestinal, com nanopartículas de quitosana. Pan et al. (2002) conseguiram induzir a redução da glicemia, em função da linha de base, em até $50 \%$, administrando $21 \mathrm{UI} / \mathrm{kg}$ de insulina nanoestruturada para ratos diabéticos, que apresentaram início da queda da glicêmia, 10 horas após a administração oral, perdurando até a vigésima quarta hora. Lin e colaboradores (2007) obtiveram resultados semelhantes $(60 \%)$, quando administraram $30 \mathrm{UI} / \mathrm{kg}$ de insulina nanoestruturada aos ratos diabéticos. Todavia, a redução da glicemia teve início já 
nas primeiras 3 horas de ensaio.

No presente trabalho foram administradas doses orais de $50 \mathrm{Ul} / \mathrm{kg}$ de insulina na forma pura, nanoencapsulada e nanoencapsulada, incorporada a uma matriz lipídica. Nos dois primeiros tratamentos o comportamento das variáveis glicêmia e insulinemia foram semelhantes ao grupo controle. A explicação para tal resposta no primeiro caso, pode ser atribuída à ação bacteriana sobre a insulina, degradando-a.

No segundo caso, a provável explicação para ausência de resposta pode advir de dois fatores:

I) Mesmo em dose mais elevada que as relatadas na literatura, ao adentrar o rúmen, as nanopartículas sofreram uma diluição no líquido ruminal, o que dificultou sua absorção no intestino delgado. Esta é suportada pelas observações de Ma e Lim (2003), que, ao utilizarem monocamadas de células Caco-2, como modelo de permeação de mucosa, concluíram que a capacidade de absorção é dependente da dose, da temperatura e da concentração de saturação das nanopartículas.;

II) Por se tratarem de nanopartículas catiônicas, estas têm grande afinidade por glicoproteínas. Segundo Arcuri e Matos (1992) o mecanismo de adesão das bactérias ruminais à fibra vegetal ocorre pela interação direta entre as glicoproteínas de membrana, presentes no glicocálice bacteriano e a fibra. Assim, as partículas se aderem à superfície bacteriana e ficam retidas no rúmen por um maior tempo e, com isso, têm parte da insulina liberada nesse local. As nanopartículas que conseguem passar pelo rúmen, não atingem o intestino delgado em quantidade e ou suficiente carregada para que haja uma detecção do efeito biológico pelas técnicas empregas no experimento.

O tratamento com $50 \mathrm{Ul} / \mathrm{kg}$ nanoencapsulada incorporada a uma matriz lipídica (V.O.) na vigésima quarta hora de experimento apresentou uma sensível elevação nos teores plasmáticos de insulina $(42,9 \pm 24,9 \mu \mathrm{UI} / \mathrm{mL})$. Paralelamente a glicemia apresentou queda para $79,8 \pm 4.3 \%$ da linha de base. Estes resultados são indicativos de que houve permeação da mucosa intestinal pela nanopartícula e que a atividade biológica da insulina foi mantida durante a permeação.

Possivelmente, durante o processo de incorporação, a matriz lipídica adsorveu-se à superfície da nanopartícula, promovendo a interação entre seus grupos carboxilados terminais, carregados negativamente e a superfície positiva da quitosana. Ao adentrar o rúmen, a gordura, altamente saturada impediu o contato 
entre partícula e a bactéria e, simultaneamente, criou uma proteção na interface líquido/partícula, reduzindo a liberação prematura da insulina no rúmen. Ao adentrar o intestino delgado, o contato com a lipase removeu a matriz lipídica e liberou a nanopartícula, podendo esta ser absorvida por endocitose via receptores (EMR), endocitose absortiva independente de receptores e mais eficientemente pela via para celular (MASOTTI e ORTAGGI, 2009; WONG, 2009). 


\section{CONCLUSÕES}

- A insulina não foi capaz de produzir benefícios reprodutivos que justifiquem seu uso em protocolos de superovulação de ovelhas, pelo menos na dose empregada.

- A concentração subfisiológica de insulina, obtida com a indução do diabetes, durante o período experimental, desencadeou uma série de alterações metabólicas, que, em conjunto, comprometeram os índices de desempenho reprodutivo relacionados ao processo de superovulação e induziram um quadro inicial de regressão de CL.

- As uso de ovelhas como modelo animal para estudo dos efeitos reprodutivos da insulina foi satisfatório, uma vez que, foi obtido a condição de hipoinsulinemia e hiperinsulinemia e, nos caso da primeira influenciou negativamente o desempenho reprodutivo.

- A formulação de insulina nanoestruturada sem proteção lipídica liberou 92,1 \pm $3,01 \%$ da quantidade inicial de insulina, in vitro, porém o padrão desejado de liberação sustentada não foi atingido. No teste in vivo, a redução da glicemia foi apenas parcial (em média $60,8 \pm 3,2 \%$ em relação à linha de base).

- O sistema composto por nanopartículas incorporadas à matriz lipídica, no teste in vitro, liberou apenas $15,6 \pm 4,9 \%$ da quantidade inicial. Entretanto, foi capaz de carrear a insulina, ao longo do trato digestivo de um ruminante, no teste in vivo e compatibilizar sua permeação através da mucosa intestinal, mantendo a atividade biológica do hormônio, pois, embora parcial, houve redução da glicemia (em média 79,88 $\pm 4,3 \%$ em relação à linha de base). 


\section{REFERÊNCIAS BIBLIOGRÁFICAS}

ADAMIAK, S. J.; MAKIE, K.; WATT, R. G.; WEBB, R; SINCLAR, K.D. Impact of nutrition on oocyte quality effects of body composition and diet leading hyperinsulinemia in cattle. Biology Reproduction, v.73, n.5, p. 918 - 926, 2005.

ADASHI, E. Y.; HSUEH, A.J.; YEN, S.S. Insulin enhancement of luteinizing hormone and follicle-stimulating hormone release by cultured pituitary cells. Endocrinology, v.108,n.4, p.1441-9, 1981.

ADEWUYI, A. A.; GRUYS, E.; VAN EERDENBURG, F. J. C. M. Non esterified fatty acids (NEFA) in dairy cattle. A review. Veterinary Quaterly, v. 27, n. 3, p. 117-126, 2005.

AGNIHOTRI, S.A.; MALLIKARJUMA, N.N.; AMINABHAVI, T.M. Recents advances on chitosan-based micro and nanoparticles in drug delivery. Journal of Controlled Release, v.100, p. 5-28, 2004.

ALMEIDA, F. R.; MAO, J.; NOVAK, S.; COSGROVE, J. R.; FOXCROFT, G. R. Effects of different patterns of feed restriction and insulin treatment during the luteal phase on reproductive, metabolic, and endocrine parameters in cyclic gilts. Journal of animal science, v. 79, p. 200-212, 2001

ARANAZ, I.; MENGÍBAR, M.; HARRIS, R.; PAÑOS, I.; MIRALLES, B.; ACOSTA, N.; GALED, G.; HERAS, A. Functional characterization of chitin and chitosan. Current Chemical Biology, v. 3, p.203-230, 2009.

ARCURI, P. B. ; MATOS, L. L. Microbiologia do Rúmen. Informe Agropecuário, v. 16, n. 175, p. 5-8, 1992.

ASHWORTH, C. J. Maternal and conceptus factors affecting histotrophic nutrition and survival of embryos. Livestock Production Science, v. 44, p. 99-105, 2005.

AUGUSTIN, R. ; POCAR, P.; WRENZYCKI, C.; NIEMANN, H.; FISCHER, B. Mitogenic and anti-aepoptotic activity of insulin on bovine embryos produced in vitro. Reproduction, v. 126, p.91-99, 2003.

BALLESTER, J.; MUÑOZ, M. C.; DOMINGUEZ, J.; PALOMO, M. J.; RIVERA, M.; RIGAU, T.; GUINOVART, J. J.; RODRIGUEZ-GIL, J. E. Tungstate administration improves the sexualand reproductive function in female rats with streptozotocininduced diabetes. Human Reproduction, v. 39, p.1-8, 2007. 
BARIL, G.; BREBION, P.; CHESNÉ, P. Manual de Formación práctica para el transplante de embriones em ovejas y cabras. Roma: Organización de las Naciones Unidas para la Agricultura y la Alimentación, 175 p., 1995.

BARROS, S. C. F.; CAVALCANTE, R. N.; CARVALHO, T. V.; DIAS, F. S.; QUEIROZ, D. C.; VASCONCELLOS, L. C. G; NASCIMENTO, R. F. Produção e caracterização de esfera de quitosana modificada quimicamente. Revista Iberoamericana de Polímero, v.7, n.4, p.32-246, 2006.

BASSETT, J. M.; WESTON, R. H.; HOGAN, J. P. Dietary regulation of plasma insulin and growth hormone concentrations in sheep. Australian Journal of Biological Science, v. 24, p. 321-330, 1971. ver as pg no pubmed

BAYAT, A.; LARIJANI, B.; AHMADIAN, S.; JUNGINGER, H.E.; RAFIEE-TEHRANI, M. Preparation and characterization of insulin nanoparticles using chitosan and its quaternized derivatives. Nanomedicine: Nanotechnology, Biology and Medicine, 2008.

BELL, A. W.; BAUMAN, D. E. Adaptations of glucose metabolism during during pregnancy and lactation. Journal of Mammary Gland Biology and Neoplasia, v. 2, p. 265-278, 1997.

BERTAN, C. M.; BINELLI, M.; MADUREIRA, E. H.; TRALDI, A. S. Mecanismos endócrinos e moleculares envolvidos na formação do corpo lúteo e na luteólise revisão de literatura. Brazilian Journal of Veterinary Research and Animal Science, v. 43, n. 6, p. 824-840, 2006

BOBE, G.; YOUNG, J. W.; BEITZ, D. C. Invited Review: Pathology, etiology, prevention, and treatment of fatty liver in dairy cows. Journal of Dairy Science, $v$. 87, p.3105-3124, 2004

BLANCHE, D.;ZHANG, S.; MARTIN, B. Dynamic and integrative aspects of the regulation of reproduction by metabolic status in male sheep. Reproduction, Nutrition and Development, v.46, n. 4, p.379-390, 2006.

BONADONNA, R. C.; SACCOMANI, M. P.; COBELLI, C.; DEFRONZO, R. A.,Effect of Insulin on System A Amino Acid Transport in Human Skeletal Muscle. The Journal of Clinical Investigation, v.91, p. 514-521, 1993.

BOONSONGRIT, Y.; MUELLER, B.W.; MITREVEJ, A. Characterization of drugchitosan interaction by HNMR, FTIR and isothermal titration calorimetry. European 
Journal of Pharmaceutics and Biopharmaceutics, v. 69, p. 388-395, 2008.

BOYLE, M.E., Optimizing the Treatment of Type 2 Diabetes Using Current and Future Insulin Technologies. MEDSURG Nursing, v. 17,N. 6, p.382-390, 2008.

BRANNON-PEPPAS, L.; GHOSN, B.; CORNETTA, K. Encapsulation of nucleic acids and opportunities for cancer treatment. Pharmaceutical Research, v.24, n.4, p.61827, 1997.

BRUNING, J.C.; GAUTAM, D.; BURKS, D.J.; GILLETTE, J.; SCHUBERT, M.; ORBAN, P.C.; KLEIN, R.; KRONE, W.; MULLER-WIELAND, D.; KAHN, C.R. Role of Brain Insulin Receptor in Control of body weight and Reproduction. Science, v. 289, p. 2122-2125, 2000.

BURNOL, A.; EBNER, S.;FERRE, P.; GIRARD, J. Regulation by insulin of glucose metabolism in mammary gland of anaesthetized lactating rats: Stimulation of phosphofructokinase-1 by fructose 2,6-bisphosphate and activation of acetyl-CoA carboxylase. The Biochemical Journal,v 254, p.11-14, 1988.

BUTLER, W.R. Energy balance relationships with follicular development, ovulation and fertility in postpartum dairy cows. Livestock Production Science, v. 83, p. 211218, 2003.

CAHILL, J. P.; SAUMANDE, J.; RAVAULT, J. P.; BLANC, M.; THIMONIER, J.; MARIANA, J. C.; MAUL, P. Hormonal and follicular relationships in ewes of high and low ovulation rates. Journal of Reproduction and Fertility, v. 62, p. 141-150, 1981.

CALLAGHAN, D.; YAAKUB, H.; HYTTEL, P.; SPICER, L. J.; BOLAND, M. P. Effect of nutrition and superovulation on oocyte morphology, follicurar fluid composition and systemic hormone concentration in ewe. Journal of Reproduction and Fertility, v. 118, p.303-313, 2000.

CALVO, P.; REMUNAN-LOPEZ, C.; VILA-JATO. J. L.; ALONSO, M. J. Novel hydrophilic chitosan-polyethylene oxide nanoparticles as protein carriers. Journal of Applied Polymer Science, v. 63, n. 1, p. 125-132, 1997.

CANDY, S.; BUZE, M. and CROUCH, R. Protective Role of Superoxide Dismutase against Diabetogenic Drugs. European Journal of Clinical Investigation, v.70, n. 3, p.650-658, 1982. 
CARA, J. F.; ROSENFIELD, R. L. Insulin - like growth factor I and insulin potentiate luteinizing hormone - induced androgen synthesis by rat ovarian thecal - interstitial cells. Endocrinology, v.123, n.2, p. $733-739,1998$.

CARVALHO, N. E.; CARVALHO, N.A.S.; FERREIRA, L.M. Experimental model of induction of diabetes mellitus in rats. Acta Cirurgica Brasileira, v.18, p. 60-64, 2003.

CERVERO, A.; DOMÍNGUEZ, F.; HORCAJADAS, J. A.; QUIÑONERO, A.; PELLCERR, A.; SIMÓN, C. The role of the leptin in reproduction. Current Opinion in Obstetrics and Gynecology, v. 18, p.297-303, 2006.

CHAMBERLAIN, C S; SPICER, L J. Hormonal control of ovarian cell production of insulin-like growth factor binding proteins. Molecular and Cellular Endocrinology, v. 182, n.1, p. $69-81,2001$.

CHAGAS, L. M.; BASS, J. J.; BLACHE, D.; BURKE, C. R.; KAY, J. K.; LINDSAY, D. R.; LUCY, M. C.; MARTIN, G. B.; MEIER, S.; RHODES, F. M.; ROCHE, J. R.; THATCHER, W. W.; WEBB, R. Invited Review: New perspectives on the roles of nutrition and metabolic priorities in the subfertility of high-producing dairy cows. Journal of Dairy Science, v. 90, p.4022-4032, 2007.

CHEN, Y; MOHANRAJ, V.J.; WANG, F.; BENSON, H.A.E. Designing ChitosanDextran Sulfate Nanoparticles Using Charge Ratios. AAPS Pharmaceutical Science Technology, v. 8, n. 4, p. E1-E9, 2007.

CHILLIARD, Y.; FERLAY, A.;FAULCONIER, Y.; BONNET, M.; ROULE, J.; BOCQUIER, F. Adipose tissue metabolism and its role in adaptation to undernutrition in ruminants. Proceedings of the Nutrition Society, v.59, p.127-134, 2000.

CHILLIARD, Y.; DELAVAUD, C.;BONNET, M. Leptin expression in ruminants: Nutritional and physiological regulations in relation with energy metabolism. Domestic Animal Endocrinology ,v. 29, p. 3-22, 2005.

CHOWDHURY, S. A.; ORSKOV, E. R. Protein energy relationships with particular references to energy undernutrition: a review. Small Ruminant Research, v. 26, p. I7, 1997.

CHRISTMAN, S. A.; BAILEY, M. T.; HEAD, W. A.; WHEATON, J. E. Induction of ovarian cystic follicles in sheep. Domestic Animal Endocrinology, v. 19, p. 133146, 2000. 
CLARKE, I. J.; HORTON, R. J. E.; DOUGHTON, B. W. Investigation of the mechanism by with insulin-induced hypoglycemia decreases luteinizing hormone secretion in ovariectomized ewes. Endocrinology, v.127, p,1470-1472, 1990.

COSTA, S.F. ; PEREIRA, M.N. ; MELO,L.Q.; RESENDE JÚNIOR, J.C.; CHAVESM.L. . Alterações morfológicas induzidas por butirato, propionato e lactato sobre a mucosa ruminal e a epiderme de bezerros - I Aspectos histológicos. Arquivo Brasileiro de Mededicina Veteterinaria Zootecnil, v.60, n.1, p.1-9, 2008

COSTELLO, P.M.; ROWLERSON, A; ASTAMAN, N. A.; ANTHONY, F. E. W.; SAYER, A. A.; COOPER, C.; HANSON, M. A.; GREEN, L.R. Peri-implantation and late gestation maternal undernutrition differentially affect fetal sheep skeletal muscle development. Journal of Physiology. v. 586, p. 2371-2379, 2008

COUVREUR, P., BARRATT, G., FATTAL, E, LEGRAND, P., VAUTHIER, C. Nanocapsule Technology: a review. Critical Reviews in Therapeutic Drug Carrier Systems, v. 19, p. 99-134, 2002.

COX, N. M.; MEURER, K.A.; CARLTON, C.A.; TUBBS, R.C.; MANNIS, D.P. Effects of diabetes mellitus during the luteal phase of the estrous cycle on preovulatory follicular function, ovulation and gonaditrophis in gilts. Journal of Reproduction and Fertility, v.101, p.77-86, 1994.

COX, N. M.; STUART, M. J.; ALTHEN, T. G.; BENNETT, W. A.; MILLER, H. W. Enhancement of Ovulation Rate in Gilts by Increasing Dietary: Energy and Administering Insulin during Follicular Growth .Journal Animal Science , v.64:, p.507-516, 1987.

DAVIES-MOREL, M.C.G.; BECK. N.F.G. A comparison of plasma gowth hormone, insulin, free fatty acid and glucose concentrations during oestrus and early pregnancy in Clun Forest ewe lambs and ewes. Small Ruminant Research, v. 48, p. 127-134, 2003.

DE HEDGE, G. A; COLBY, H. D.; GOODMAN, R. L. Fisiologia Endócrina Clínica. Rio de Janeiro: Intrelivros, 1988, p. 178-183.

DEACHAPUNYA, C.; PALMER, D. M.; O'GRADY, S. M. Insulin stimulates transepithelial sodium transport by activation of a protein phosphatase that increases Na-K ATPase activity in endometrial epithelial cells. Journal of General Physiology, v, 114, n. 4, p. 562-574, 1999.

DICKINSON, J. E. ; MEYER, B. A. ; CHMIELOWIEC, S. ; PALMER, S. M. Streptozocin-induced diabetes mellitus in the pregnant ewe. American journal of 
obstetrics and gynecology, v. 165, n. 1, p. 1673-1677, 1991 a.

DICKINSON, J. E. ; MEYER, B. A. ; CHMIELOWIEC, S. ; PALMER, S. M. The metabolic clearance rate of epinephrine in the fetus of the diabetic ewe. American Journal of Obstetrics and Gynecology, v. 165, n. 1, p. 1655-1660, 1991 b.

DIMITRIU, S.; CHORNET, E. Inclusion and release of proteins from polysaccharidebased polyion complexes. Advanced Drug Delivery Reviews, v. 31, p. 223-246, 1998.

DRAGHET, K. I. Association phenomenon in highly acetylated chitosan gel. Polymers Gels Network, v. 4, p.143-151, 1996.

DENKBAS, E. B.; OTTENBRITE, R. M. Perspectives on: Chitosan Drug Delivery Systems Based on their Geometries. Journal of Bioactive and Compatible Polymers, v. 21; 351- 368, 2006.

DULEBA, A. J.; SPACZYNSKI, R. Z.; OLIVE, D. L.; BEHRMAN, H. R. Effects of insulin and insulin-like growth factors on proliferation of rat ovarian theca-interstitial cells. Biology of Reproduction, v.56, n.4. p. 891-897, 1997.

DULEBA, A. J.; SPACZYNSKI, R. Z.; OLIVE, D. L.; BEHRMAN, H. R. Divergent mechanisms regulate proliferation/survival and steroidogenesis of theca-interstitial cells. Molecular Human Reproduction, v.5, n.3, p. 193-198, 1999.

DULEBA, A. J.; SPACZYNSKI, R. Z.; OLIVE, D. L. Insulin and insulin - like growth factors I stimulate the proliferation of human ovarian theca-interstitial cells. Fertility and Sterility, v.69, n.2, p. 335-340, 1998.

DURAN, N.; MATTOSO, L.H.C.; MORAI, P.C. Nanotecnologia: Introdução, preparação e caracterização de nanomateriais e exemplos de aplicação. Artiliber (ed), São Paulo. 208p.,2006

EMEA: The European Agency for the Evanluation of Medicinal Products Evanluation of Medicines for Human Use; Points to consider on the need for assessment of reproductive toxicity of human insulin analogues; London, March, 2002. Disponivel em :www.emea.europa.eu , 10/05/2009.

EMERY, R. S.; LIESMAN, J. S.; HERDET, T. H. Metabolism of long chain fatty acids by ruminant liver. Journal of Nutrition, v. 122, p. 832-837, 1992. 
EVANS, G.; DOBIAS, M.; KING, G.J.; ARMSTRONG, D.T. Estrgen, androgen and progesterone byosinthesis by theca and granulosa of preovulatory follicles in the pig. Biology of Reproduction, v.25, p.673-682, 1981.

FARIN, C. E.; MOELLER, C. L.; SAWYER, H. R.; GAMBONI, F.; NISWENDER, G. D. Morphometric analysis of cell types in the ovine corpus luteum throughout the estrous cycle. Biology of Reproduction, v. 35, p. 1299-1308, 1986.

FEHLMANN, M.; CAM, A.L.; FREYCHET, P. Insulin and Glucagon Stimulation of Amino Acid Transport in Isolated Rat Hepatocytes. The Journal of Biological Chemistry, v. 254, n. 20, p. 10431-10437, 1979.

FERNANDES, V. C.; ENADAI, A. M. L.; MILLÁN, R. D. S.; ALVES, R. J.; JÚNIOR, A. S. C. Caracterização físico-química de complexos de insulina:dimetil- $\beta$-ciclodextrina e insulina:hidroxipropil- $\beta$-ciclodextrina e avaliação da influência do tipo de complexo na produção de microesferas biodegradáveis, Revista Brasileira de Ciências Farmacêuticas , v. 43, n. 4, p.544-553 , 2007.

FERNANDEZ-URRUSUNO, R.; CALVO, P.; REMUÑÁN-LÓPEZ, C.; VILA-JATO, J. L.; ALONSO, M. J. Enhancement of nasal absorption of insulin using chitosan nanoparticles. Pharmaceutical Research, v. 16, p. 1576-1581, 1999.

FORMARIZ, T. P.; WANCZINSKI, B. J.; SILVA JÚNIOR, A. A.; SCARPA, M. V.; OLIVEIRA, A. G. Biotecnologia de sistemas coloidais aplicável na otimização do efeito terapêutico de fármacos usados no tratamento do câncer. Infarma, v.16, n.1-2, p. 301-313, 2004.

FORTUNE, J. E.; RIVERA, G. M.; YANG, M. Y. Folliculas development: the role of follicular microenvironment in selection of the dominant follicle. Animal Reproduction Science, v. 82-83, p. 109-126, 2004.

FRANCO, G.L.; ALVES, J.M.; OLIVEIRA FILHO, B.D.; GAMBARINE, M.L. Interação entre nutrição e reprodução em vaca de corte. Revista do Conselho Federal de Medicina Veterinária, n. 32, p. 23-32, 2004.

GARNSWORTHY, P. C.; LOCK, A.; MANN, G. E.; SINCLAIR, K. D.; WEBB, R., Nutrition, Metabolism, and Fertility in Dairy Cows: 1. Dietary Energy Source and Ovarian Function. Journal Dairy Science, v. 91, p. 3814-3823, 2008.

GAYTON, A.C.; HALL, J.E. Tratado de Fisiologia Médica. $10^{\circ}$ ed. Rio de Janeiro: Guanabara Koogan, 2002, p. 214-219. 
GERICH, J. E. Novel Insulins: Expanding Options in Diabetes Management. The American Journal of Medicine, v.113, p. 308-316, 2002.

GONG, J. G. Influence of metabolic hormones and nutrition on ovarian follicles development in cattle: practical implications. Domestic Animal Endocrinology, v. 23, n.1-2, p. 229-241, 2002.

GORLA JUNIOR, J.A. ; FAGUNDES, D.J.; PARRA, O.M.; ZAIA, B.V.; BANDEIRA, C.O.P. Fatores hepatotróficos e regeneração hepática. parte i: o papel dos hormônios. Acta Cirurgica Brasileira, v.16, n.3, p. 2001. disponível em $<$ http://www.scielo.br/scielo.phpscript=sci_arttext\&pid=S010286502001000300011\&Ing=en\&nrm=iso>. Acessado em 20/05/2009. doi: $10.1590 / \mathrm{S} 0102-86502001000300011$.

GHOUGH, S.C.L. A review of human and analogue insulin trials. Diabetes Research and Clinical Practice, v. 77, p. 1-15, 2007.

GRAY, A. C.; BARTOL, F. F.; TARLETON, B. J.; WILEY, A. A. A.; JOHNSON, G. A.; BAZER, F.W.; PENCER, T.E., Developmental Biology of Uterine Glands. Biology of Reproduction, v.65,p. 1311-1323, 2001.

GUIDO, S. I.; ANDRADE, J. C. O.; GUIDO, F. C. L.; OLIVEIRA, M. A. L.; LIMA, P. F.; MOURA, R. T. D. SANTOS, V. F.; CAVALCANTI, C. C. Avaliação de corpos lúteos de receptoras caprinas. Revista Brasileira de Reprodução Animal, v.27, n. 3, p. 491-493, 2003.

GUPTA, K. C.; JABRAIL, F. H. Glutaraldehyde cross-linked chitosan microspheres for controlled release of centchroman. Carbohydrate Research, v. 342, n. 5, p. 22442252, 2007.

GUTERRES, S. S; BENVENUTTI, E.V; POHLMANN, A.R. Nanopartículas poliméricas para a administração de fármacos in: Duran, N, Mettoso, L.H.C; Morais .P.C. Nanotecnologia: Introdução preparação e caracterização de nanomateriais e exemplo de aplicação. Artliber(ed) São Paulo, 161-166, 2006.

HATANAKA, T.; HATANAKA, Y.; TSUCHIDA, J.;GANAPATHY ,V. ;SETOU, M., Amino Acid Transporter ATA2 Is Stored at the trans Golgi Network and Released by Insulin Stimulus in Adipocytes. The Journal of Biological Chemistry, v. 281, n. 51, p. 39273-39284, 2006.

HANS, M.L.; LOWMAN, A. M. Biodegradable nanoparticles for drug delivery and 
targeting. Current Opinion on Solid State Materials Science, v. 6, p.319-327, 2002.

HARVEY, M. B.; KAYE, P. L. Insulin increases the cell number of the inner cell mass and stimulates morphological development of mouse blastocysts in vitro. Development, v. 110, p. 963-967, 1990.

HAYIRLI, H. The Role of Exogenous Insulin in the Complex of Hepatic Lipidosis and Ketosis Associated with Insulin Resistance Phenomenon in Postpartum Dairy Cattle. Veterinary Research Communication, v. 30, p. 749-774, 2006.

HAX, L.T.; SCHNEIDER, A; PFEIFER, L. F. M.; SILVA NETO, J. W.; ANTUNES, M. M. SARAY, L.R.; DEL PINO,F. A. B; CORREAA, M. N. Influência do jejum e da administração de insulina sobre o número de folículos ovarianos em ovelhas submetidas à sincronização de cios. IN: $35^{\circ}$ CONGRESSO BRASILEIRO DE MEDICINA VETERINÁRIA, 19 A 22 de outubro Gramado, 2008. CD-ROM. Rio Grande do Sul, COBRAVET, 2008. R0104-1.

HEYNER, S., RAO, I. V., JARRET, L., AND SMITH, R. M. Preimplantation mouse embryos internalise maternal insulin via receptor-mediated endocytosis: pattern of uptake and functinal correlations. Developmental Biology. v.134, p.48-58, 1989

HILD-PETITO, S.; OTTOBRE, A. C.; HOYER, P. B. Comparison of subpopulations of luteal cells obtained from cyclic and superovulated ewes. Journal of Reproduction and Fertility, v. 80, p. 537-544, 1987.

HUNTER, M. G.; ROBINSON, R. S.; MANN, G. E.; WEBB, R. Endocrine and paracrine control of follicular development and ovulation rate in farm species. Animal reproduction Science, v. 82-83, p. 461-477, 2004

HYDE, R.; TAYLOR, P.M.; HUNDAL, H.S., Amino acid transporters: roles in amino acid sensing and signalling in animal cells. Biochemical Journal, v. 373, p.1-18, 2003.

JUNG, T.; KAMM, W.; BREITENBACH, A.; KAISERLING, E.; XIAO, J.X.; KISSEL, T. Biodegradable nanoparticles for oral delivery of peptides: is there a role for polymers to affect mucosal uptake? European Journal of Pharmaceutics and Biopharmaceutics, v.50, p. 147-160, 2000.

KASANICKI, M. A.; PILCH, P. F. Regulation of glucose-transporter function. Diabetes Care, v. 13, n. 3, p. 219- 227, 1990. 
$\mathrm{KATOH}, \mathrm{N}$. Relevance of apolipoproteins in the development of fatty liver and fatty liver-related peripartum diseases in dairy cows. Journal of Veterinary Medicine Science, v. 64, n. 4, p. 293-307, 2002.

KAYNE, P. L.;GARDNER, G., Preimplantation access to maternal insulin and albumin increases fetal growth rate in mice. Human Reproduction, v. 14, n. 12, p. 30523059, 1992.

KEZELE, P.R.; NILSSON, E.E.; SKINNER M.K. Insulin but not insulin-like growth factor-1 promotes the primordial to primary follicle transition. Moleculas and Cellular Endocrionology, v. 192, p. 37-43, 2002.

KOFUJI, K.; QIAN, C. J.; NISHIMURA, M.; MURATA, Y.; KAWASHIMA, S. Ralationship between phisicochemical characteristics and functional propierties of chitosan. European Polymer Journal, v. 41, p. 2784-2791, 2005.

KOSIOR-KORZECKA, U.; BOBOWIEC, R.. Changes in the Level of Endogenous Leptin, FSH, 17b-Oestradiol and Metabolites during Lupin-induced Increase in Ovulation Rate in Ewes. Journal of Veterinary Medicine, v. 50, p. 343-349, 2003.

KOUTKIA, P.; CANAVAN, B.; JOHNSON, M. L.; DePAOLI, A.; GRINSPOON, S. Characterization of leptin pulse dynamics and relationship to fat mass, growth hormone, cortisol, and insulin. American Journal of Physiology. Endocrinology and Metabolism, v. 285, n.2, p.372-379, 2003.

KREUTER, J.; MAULER, R.; GRUSCHKAU, H.; SPEISER, P.P. The use of new polymethylmethacrylate adjuvants for split influenza vaccines. Cell Biology, v.44, p. $12-9,1975$.

LADISCH, M. R.; KOHLMANN, K. L. Recombinant Human Insulin. Biotechnology Progress, v. 8, p.469-478, 1992.

LAUGHLIN, G.; DOMINGUEZ, C.; YEN, S. Nutritional and Endocrine-Metabolic Aberrations in Women with Functional Hypothalamic Amenorrhea. Journal of Clinical Endocrinology \& Metabolism, v.83, n.1, p.25-32, 1998.

LEE, V.; LEO, T. O. L.; BILLY, K. C. Chow Gonadotropin-releasing hormone: regulation of the GnRH gene. The FEBS Journal, v. 275 , p. 5458-5478, 2008.

LEENANURUKSA, D.; MCDOWELL, G. Experimental Diabetes in Lactating Sheep: 
Effects of Alloxan on Plasma Insulin, and MilK Characteristics. Australian Journal of Biologycal Sciences, v. 41, n. 2, p.223-229,1988A.

LEENANURUKSA, D.; MCDOWELL, G. Control of Glucose Homeostasis in Lactating Ewes: Use of the Alloxan-diabetic/Insulin-stabilized Ewe to Study Effects of Insulin and Growth Hormone. Australian Journal of Biologycal Sciences, v. 41, n. 2, p.421-433, 1988B.

LEGRAND, P., BARRATT, G., MOSQUEIRA, V., FESSI, H., DEVISSAGUET, J. P. Polymeric nanocapsules as drug delivery systems: a review. S.T.P. Pharma Sciences, v. 9, p. 411-418, 1999.

LEMLEY, C.O.; BUTLER, S.T.; BUTLER, W.R., WILSON, M.E. Short Communication: Insulin Alters Hepatic Progesterone Catabolic Enzymes Cytochrome P450 2C and 3A in Dairy Cows. American Dairy Science Association, v. 91, p. 641-645, 2008.

LEROY, J. L. M. R.; VAN SOOM, A.; OPSOMER, G.; BOLS, P. E. J. Animal, v. 2, n. 8, p. 1120-1127, 2008.

LIN, Y.; MI, F.; CHEN, C.; CHANG, W.; PENG, S.; LIANG, H.; SUNG, H. Preparetion and characterization of nanoparticles shell whith chitosan for oral insulin delivery. Biomacromolecules, v. 8, p. 146-152, 2007

LIU, J.; ZHANG, S. M.; CHEN, P. P.; CHENG, L.; ZHOU, W.; TANG, W. X.; CHEN, Z. W.; KE, C. M. Controlled release of insulin from PLGA nanoparticles embedded within PVA hydrogels. Journal of Material Science: Material in Medicine, v. 18, p. 2205-2210, 2007.

LOBLEY, G. E. Control of the Metabolic Fate of Amino Acids in Ruminants: a review. Journal of Animal Science, v. 70, p.3264-3275, 1992.

LORENZONI, P. J.; SCOLA, R. H.; VIEIRA, N.; VAINZOF, M.; CARSTEN, A. L.; WERNECK, L. C. A novel missense mutation in the caveolin-3 gene in rippling muscle disease. Muscle \& Nerve, v. 36, v. 2 p. 258-60, 2007.

LOZANO, J. M.; LONERGAN, P.; BOLAND, M. P.; CALLAGHAN, D. O. Influence of the effectiveness of superovulation programmes in ewes; effects on oocyte quality and post-fertilization development. Reproduction, v.125, n.4, p. 543-553, 2003.

LUNN, S.F.; FRASER, H. M.; MASON, H. D. Structure of the corpus luteum in the 
ovulatory polycystic ovary. Human Reproduction, v. 17, n. 1, p. 111-117, 2002.

MANN, G. E.; GREEN, M. P.; SINCLAIR K. D.; DEMMERS, K. J.; FRAY, M. D.; GUTIERREZ, C. G.; CAR, N. S.; WORTHY, P. C.; WEBB, R.; GARNSWORTHY, P. C.; Effects of circulating progesterone and insulin on early embryo development in beef heifers. Animal reproduction Science, v. 79, n.1-2, p. 71-79, 2003.

MARTIN, G. B.; MILTON, R. H.; DAVIDSON, G. E.; HUNZICKER, G. E. B.; LINDSAY, D. R.; BLANCHE, D. Natural methods for increasing reproductive efficiency in small ruminants. Animal Reproduction Science, v.82-83, 2004.

MASOTTI, A.; ORTAGGI, G. Chitosan micro and nanospheres: Fabrication and aplications for drug and DNA delivery. Nini-Reviews in Medical Chemistry, v. 9, p. 463-469, 2009.

MATAMOROS, I. A.; COZ, N. M.; MOORE, A. B. Effects of exogenous insulin and body condition on metabolic hormones and gonadotropin - induced follicular development in prepuberal gilts. Journal of Animal Science, v.69, n.5, p. 20812091, 1991.

MEDLICOTT, N. J.; WALDRON, N. A.; FOSTER, T. P. Sustained release veterinary parenteral products. Advanced Drug Delivery Reviews, v. 56, p. 1345-1365, 2004.

MI, F. L.; KUAN, C. Y.; SHYU, S. S.; LEE, S. T.; CHANG, S. F. The study of gelation kinetics and chain-relaxation properties of glutaraldehyde cross-linked chitosan gel and their effects on microspheres preparation and grug release. Carbohydrate Polymers, v. 41, n. 4, p. 389-396, 2000.

MIODOVINIK, M.; MOMOUNI, F.; BERCK, M.; CLARCK, K. Alloxan-induced diabetes mellitus in the pregnant ewe: metabolic and cardiovascular effects on the mother and her fetus. American journal of obstetrics and gynecology , v. 160, p. 1239-1244, 1989.

MUNIR, I; YEN, H. W.; GELLER, D. H.; TORBATI, D.; BERDEN, R. M.; WEITSMAN, S. R.; AGARWAL, S. K.; MAGOFFIN, D. A. Insulin augmentation of 17 alphahidroxylase, activity is mediated by phosphatidyl inositol 3-kinase but not extracellular signal-regulated kinase- $1 / 2$ in human ovarian theca cells. Endocrinology, v. 145, n. 4, p. 175-183, 2004.

NÉMATI, F.; DUBERNET, C.; FESS,I H.; VERDIERE, A.C.; POUPON, M.F. Reversion of multidrug resistance using nanoparticles invitro: influence of the nature of the 
polymer. International Journal of Pharmacology, v. 138, p.237 - 46, 1996.

NEVES, M.M.; MARQUES JR., A.P. Tamanho da amostra para estudo da proporção volumétrica dos constituintes do corpo lúteo bovino. Archives of Veterinary Science, v.7, n.2, p.81-85, 2002.

NEVES, M.,M.; MARQUES JR., A. P. Proporção volumétrica dos constituintes do corpo lúteo de Nelore. Arquivo Brasileiro de Medicina Veterinária e Zootecnia. v.58, n.5, p.944-946, 2006.

NISHIMOTO, H.; MATSUTANI, R.; YAMAMOTO, S.; TAKAHASHI, T.; HAYASHI, K. G.; MIYAMOTO, A.; HAMANO . Gene expression of glucose transporter (GLUT) 1, 3 and 4 in bovine follicle and corpus luteum. Journal of Endocrinology, v.2006, 188, p. 111-119, 2006.

O'DONNELL,P. B.; MCGNITHY, J. W. Preparation of microspheres by the solvent technique. Advanced Drug Delivery Reviews. n. 28, p25-42, 1997.

OIKAWA, S.; KATOH, N. Reduced concentrations of apolipoproteins B-100 and A-I in serum from cows with retained placena. Canadian Journal of Veterinary Research, $v$. 61, p. 312-314, 1997.

PAN, Y.; LI, Y.; ZHAO, H.; ZHENG, J.; XU, H.; WEI, G.; HAO, J.; CUI, F. Bioadhesive polysaccharide in protein delivery system: chitosan nanoparticles improve the intestinal absorption of insulin in vivo. International Journal of Pharmaceutics, v. 249, p. 139-147, 2002.

PANGBURN, S. H.; TRESCONY, P. V.; HELLER, J. Lysosyme degradation of partially desacetilated chitin, its films and hidrogels. Biomaterials, v.3, n. 2, p. 105-108, 1982.

PAYET, L. TERENTJEV, E. M. Emulsification and stabilization mechanisms of O/W emulsions in the presence of chitosan. Langmuir, 24, p. 12247-12252, 2008.

PICTON, H. M.; HARRIS, S. E.; MURUVI, W.; CHAMBERS, E. L.. Focus on Fertility Preservation: The in vitro growth and maturation of follicles. Reproduction, v.136, p. 703-715, 2008.

PINTO-ALPHANDARY, H.; ABOUBAKAR, M.; JAILLARD, D.; COUVREUR, P.; VAUTHIER, C.; Visualization of Insulin-Loaded Nanocapsules: In Vitro and in Vivo Studies after Oral Administration to Rats. Pharmaceutical Research, v. 20, n. 7, p. 1071-1084, 2003. 
PLUM, L.; BELGARDT, B.F.; BRUNIG, J.C. Central insulin action in energy and glucose homeostasis. The Journal of Clinical Investigation, v. 116, n. 7, p. 17611766, 2006.

PORETSKY, L. On the paradox of insulin-induce hiperandrogenism in insulinresistant states. Endocrinology Review, v.12, p. 3-13, 1991. Apud STEIN, P; BUSSMANN, L E; TESONE, M. In vivo regulation of the steroidogenic activity of rat luteal cells by insulin. The Journal of Steroid Biochemistryand Molecular Biology, v. 52 , n. 4 , p. $329,1988$.

QUESNEL, H. Locazation of binding sites for IGF - I, insulin and GH in the sow ovary. Journal Endocrinolology, v.163, n. 2, p. 363-72, 1999.

RABIEE, A. R.; LEAN, I. J.; GOODEN, J. M.; MILLER, B.G. Short-term studies of ovarian metabolism in the ewe. Animal Reproduction Science , v. 47, p. 43-58, 1997.

REID, I. M.; COLLINS. R. A. The pathology of post-parturient fatty liver in highyielding dairy cows. Investigative \& Cell Pathology. v. 3, p.237-249, 1980.

REIS, C. P.; NEUFELD, R. J.; RIBEIRO, A. J.; VEIGA, F. Nanoencapsulation I. Methods for preparation of drug-loaded polymeric nanoparticles. Nanomedicine: Nanotechnology, Biology, and Medicine. v. 2, p. 8 - 21, 2006.

REIS, C. P.; RIBEIRO, A.J.; HOUNG, S.; VEIGA, F.; NEUFELD, R. J. Nanoparticulate delivery system for insulin: Design, characterization and in vitro/in vivo bioactivity. European Journal of Pharmaceutical Sciences, v. 3 0, p. $392-$ 397, 2007.

RIBEIRO, L. A. O.; FONTANA, C. S.; WALD, V. B.; GREGORY, R. M.; MATTOS, R. C. Relação entre a condição corporal e a idade das ovelhas no encarneiramento com a prenhez. Ciência Rural, v. 33, n. 2, p.357-361, 2003.

RINAUDO, M. Chitin and chitosan: propieties and aplications. Prog. Polymer Science, v. 31, p. 603-632, 2006.

RODGERS,R. J.; O'SHEA, J. D.; BRUCE,N. W. Morphometric analysis of the cellular composition of the ovine corpus luteum. Journal of Anatomy, v. 138, n. 4, p. 757769, 1984. 
ROSENFELD, L. Insulin: Discovery and Controversy. Clinical Chemistry, v.48, n.12, p.2270-2288, 2002.

SAHMI, M.; NICOLA, E.S.; PRICE, C. A. Hormonal regulation of cytochrome P450 aromatase mRNA stability in non-luteinizing bovine granulosa cells in vitro. Journal of Endocrinology, v.190, n.1, p. 107-115, 2006.

SALADIN, R.; DE VOS, P., GUERRE-MILLO, M., LETURQUE, A., GIRARD, J., STAELS, B.; AUWERX, J. Transient increase in obese gene expression after food intake or insulin administration. Nature, v, 377, p. 527-529, 1995.

SALES, J.N.S.; DIAS, L. M. K.; VIVEIROS, A. T. M.; PEREIRA, M. N.; SOUZA, J.C. Embryo production and quality of Holstein heifers and cows supplemented with carotene and tocopherol. Animal Reproduction Science, v.106 , p.77-89, 2008.

SANTOS, A. N.; TONACK, S.; KIRSTEIN, M.; KIETZ, S.; FISCHER, B. Two insulinresponsive glucose transporter isoforms and the insulin receptor are developmentally expressed in rabbit preimplantation embryos. Reproduction, v.128 p. 503-516, 2004a.

SANTOS, A. N.; TONACK, S.; KIRSTEIN, M.; PANTALEON, M.; KAYE, P.; FISCHER, $B$. Insulin acts via mitogen - activated protein kinase phosphorylation in rabbit blastocysts. Reproduction, v.128 p. 517-526, 2004b.

SANTOS, A.N.; AUGUSTIN, R.; LAZZARI, G.; GALLI, C.; SREENAN, J. M.; FISCHER, B., The Insulin-Dependent Glucose Transporter Isoform 4 Is Expressed in Bovine Blastocysts. Biochemical and Biophysical Research Communications ,v.271, p. 753-760, 2000.

SARATH,T.; MEHROTRA, S. ;AGARWAL, S. K.; VARSHNEY, V. P.; HOQUE, M.; SHANKAR, U. ;SINGH, S. K.. Effect of insulin administration on ovarian function and estrus induction in acyclic goats. Animal Reproduction Science, v.108, p. 216-225, 2008.

SARMENTO, B.; RIBEIRO, A.; VEIGA, F.; SAMPAIO, P.; NEUFELD, R., FERREIRA, R. Alginate/Chitosan Nanoparticles are Effective for Oral Insulin Delivery. Pharmaceutical Research, v. 24, n.. 12, p. 2098-2006, 2007.

SARMENTO, B.; RIBEIRO, A.; VEIGA, F.; ERREIRA, D. Development and validation 
of a rapid reversed-phase HPLC method for the determination of insulin from nanoparticulate systems. Biomedical Chromatography, v.20, p.898-903, 2006 a.

SARMENTO, B.; RIBEIRO, A.; VEIGA, F.; ERREIRA, D. Development and characterization of new insulin containing polysaccharide nanoparticles. Colloids and Surfaces B: Biointerfaces, v. 53, p. 193-202, 2006 b.

SASAKI, S. Mechanism of insulin action on glucose metabolism in ruminants. Animal Science Journal, v.73, p. 423-433, 2003.

SCHILLO, K. K. Effect of dietary energy on control of luteinizing hormone secretion in cattle and sheep. Journal of Animal Science, v. 70, p.1271-1282, 1992.

SEKAR, N.; LAVOIE, H.A.; VELDHUIS, J.D. Concerted regulation of steroidogenic acute regulatory gene expression by luteinizing hormone and insulin (or Insulin-like growth factorl) in primary cultures of porcine granulosa-luteal cells. Endocrinology, v.141, n. 11, p. 3983-3992, 2000.

SEKAR, N.; VELDHUIS, J. D. Involvement of Sp1 and SREBP-1a in transcriptional activation of the LDL receptor gene by insulin and LH in cultured porcine granulosaluteal cells. American Journal of Physiology. Endocrinology and Metabolism, n. 287, v.1, p.E128-E135, 2004.

SELVARAJU, S.; AGARWAL, S. K.; KARCHE, S. D.; MAJUMDAR, A. C, Ovarian response, embryo production and hormonal profile in superovulated goats treatd with insulin. Theriogenology, v.59, n.5-6, p. 1459-1468, 2003.

SCHERZER, J.; GHUMAN, S. P. S.; POPE, M.; ROUTLY, J. E.; WALTER, I.; SMITH, R. F.; DOBSON, H. Follicle and oocyte morphology in ewes after treatmentwith insulin in the late follicular phase. Theriogenology, v. 71, p. 817-828, 2009.

SIGMA-ALDRICH. Product Information: Insulin from bovine pancreas <disponível em: , 2006

SILVA NETO, J. W.; SCHNEIDER, A.; PFEIFER, L. F. M.; HAX, L. T.; ANTUNES, M. M.; SARAY, L. R.; DEL PINO, F. A. B.; CORREAA, M. N. influência dos parâmetros metabólicos no diâmetro do folículo ovulatório em ovelhas submetidas ao jejum ou a aplicação de insulina. IN: $3^{\circ}$ CONGRESSO BRASILEIRO DE MEDICINA VETERINÁRIA, 19 A 22 de outubro Gramado, 2008. CD-ROM. Rio Grande do Sul, COBRAVET, 2008. R0116-1. 
SILVA, J. R.V.; FIGUEIREDO, J. R; HURK, R.V. D. Involvement of growth hormone $(\mathrm{GH})$ and insulin-like growth factor (IGF) system in ovarian folliculogenesis. Theriogenology, v. 71, p. 1193-1208, 2009

SINGLA, A. K.; CHAWLA, M. Chitosan: some pharmaceutical and biological aspects. Journal of Phamaceutical and Phamacology, v. 53, p. 1047-1067, 2001.

SOPPIMATH, K. S.; AMINABHAVI, T. M.; KULKARNI, A. R.; RUDZINSKI, W. E. Biodegradable polymeric nanoparticles as drug delivery devices. Journal of Controlled Release. v.70, p.1-20, 2001.

SOUZA, A. L.; GALEATI, G.; ALMEIDA, A. P.; ARRUDA, I. J.; GOVONI, N.; FREITAS, V. J. F.; RONDINA, D. Embryo production in superovulated goats treated with insulin before or after mating or by continuous propylene glycol supplementation. Reproduction in Domestic Animal, v. 43, p. 218-221, 2008.

SPICER, L. J. Effects of estradiol on bovine thecal cell function in vitro: Dependence on insulin and gonadotropins. Journal of Dairy Science, v. 88, n 7. p. 2412-2421, 2005.

STABENFELDT, J G; in:Cunninghn. Fisiologia Animal. 3.ed, Rio De Janeiro: Guanabara Koogan, 2004, p. 368 - 374.

SUGUNA, K.; MEHROTRA, S.; AGARWAL, S. K.; HOQUE, M.; SHANKER, U.; SINGH, S. K.; VARSHNEY, V. P. Effect of exogenous insulin administration on ovarian function, embryo/fetal development during pregnancy in goats.Animal Reproduction Science ,v.111,p. 202-213, 2009.

STEIN, P; BUSSMANN, L E; TESONE, M. In vivo regulation of the steroidogenic activity of rat luteal cells by insulin. The Journal of Steroid Biochemistryand Molecular Biology, v. 52, n. 4, p. 329-335, 1995.

SWAIN, J. E.; DUNN, R. L.; MC CONNELL, D.; GONZALEZ-MARTINEZ, J.; SMITH, G. D. Direct effects of leptin on mouse reproductive function: regulation of follicular, oocyte, and embryo development. Biology of Reproduction, v. 71, n.5, p. 1446-52, 2004.

TAHARA, Y.; HONDA, S.;KAMIYA, N.; PIAO, H.; HIRATA, A.; HAYAKAWA, E.; FUJII, T.; GOTO, M. A solid-in-oil nanodispersion for transcutaneous protein delivery. 
Journal of Controlled Release, v. 131, p. 14-18, 2008.

TANAKA, T.; NAGATANI, S.; BUCHOLTZ, D. C.; OHKURA, S.; TSUKAMURA, H.; MAEDA, K.; FOSTER, D. Central Action of Insulin Regulates Pulsatile Luteinizing Hormone Secretion in the Diabetic Sheep Model. Biology of Reproduction, v. 62, p. 1256-1261, 2000.

THE ESHRE CAPRI WORKSHOP GROUP. Human Reproduction Update, v. 12, n.3, p.193-207, 2006.

THWAITES, C. J.; EDEY T. N. Histology of the corpus luteum in the ewe: Changes during the estrous cycle and early pregnancy, and in response to some experimental treatments. American Journal of Anatomy, v. 129, n. 4, p. 2005.

TRENKLE, A. Radioimmunoassay of plasma hormone: review of plasma insulin in ruminants. Journal of Dairy Science, n. 55, v. 8, p.1200-1211, 1972.

VAN DEN HURK, R.; ZHAO, J. Formation of mammalian oocytes and their growth, differentiation and maturation within ovarian follicles. Theriogenology, v. $63, n$. 6 , p.1717-1751. 2005.

VAN HOOFF, M.;VOORHORST, F.; KAPTEIN, M.; HIRASING, R.;KOPPENAAL, C. and SCHOEMAKER, J. Insulin, Androgen, and Gonadotropin Concentrations, Body Mass Index, and Waist to Hip Ratio in the First Years after Manarche in Girls with Regular Menstrual Cycles, Irregular Menstrual Cycles, or Oligomenorrhea. Journal of Clinical Endocrinology \& Metabolism, v.85, n.4, p.1394-1400, 2006.

VAN KNEGSEL, A. T. M.; VAN DEN BRAND, H.; DIJKSTRA, J.; TAMMINGA, S.; KEMP, B. Effect of dietary energy source on energy balance, production, metabolic disorders and reproduction in lactating dairy cattle. Reproduction, Nutrition and Development, v.45, p. 665-688, 2005.

VANHOLDER, T.; LEROY, J. L. M. R.; VAN SOOM, A.; OPSOMER, G.; MAES, D.; CORYN, M.; DE KRUIF, A. Effect of non-esterified fatty acids on bovine granulosa cell steroidogenesis and proliferation in vitro. Animal Reproduction Science, v. 87, p. 33-44, 2005.

VANHOLDER, T.; OPSOMER,G.; DE KRUIF, A. Aetiology and pathogenesis of cystic ovarian follicles in dairy cattle: a review. Reproduction Nutrition and Development, v. 46, p.105-119, 2006.

VERNON, R. G.; FAULKNER, A.; HAY, W. W.; CALVERT, D. T.; FLINT, D. J. Insulin 
resistance of hind-limb tissues in vivo in lactating sheep. Biochemistry Journal, v. 270, p. 783-786, 1990.

WATANABE, M.; HAYASAKI, H.; TAMAYAMA, T.; SHIMADA ,M.. Histologic distribution of insulin and glucagon receptors. Brasilian Jornal of Medical and Biological Research.,v. 31, p. 243-256, 1998.

WATNASIRICHAIKUL,S.; DAVIES, M.; RADES, T. Preparation of Biodegradable InsulinNanocapsules from BiocompatibleMicroemulsions. Pharmaceutical Research, v.17, n. 6, p. 648-652, 2000. ( conferir data)

WEBB, R.; DUGAN, K.; QUINN, R.L.; FOULAD-NASHTA, A.A.; HUNTER, M. G. Desenvolvimento folicular em espécies mono e poliovulatórias: do feto à fertilização. Acta Scientiae Veterinariae, v. 34, n. 1, p. 95-114, 2006.

WELLS, L.A.,SHEARDOWN, H.,Extended release of high pl proteins from alginate microspheres via a novel encapsulation technique. European Journal of Pharmaceutics and Biopharmaceutics, v. 65,p. 329-335,2007.

WESTER, T. J.; LOBLEY,G. E.; BIRNIE, L. M.; LOMAX, M ., Nutrient MetabolismResearch Communication: Insulin Stimulates Phenylalanine Uptake across the Hind Limb in Fed Lambs. Journal of Nutrition. v.130, p.608-611, 2000.

WONG, T. W. Chitosan and its use in desining of insulin delivery system. Recent Patents on Drug Delivery \& Formulation, v. 3, p. 8-25, 2009.

VOGE, J. L.; SANTIAGO, C. A.; AAD, P. Y.; GOAD, D. W.; MALAYER, J.R.; SPINCER, I. J. Quantification of insulin - like growth factor binding protein mRNA using real - time PCR in bovine granulosa and theca cells: effects of estradiol, insulin, and gonadotropins. Domestic Animal Endrocinology, v. 26, n. 3, p. 241258, 2004.

ZENGSHUAN, M.; LIM, L.Y. Uptake of Chitosan and Associated Insulin in Caco-2 Cell Monolayers: A Comparison Between Molecules and Chitosan Nanoparticles. Pharmaceutical Research, v. 20, n. 11, p. 1812-1819, 2003.

ZHANG, G.; VELDHUIS, J. D. Requirement for Proximal Putative Sp1 and AP-2 cisDeoxyribonucleic Acid Elements in Mediating Basal and Luteinizing Hormone - and Insulin-Deperndent in Vitro Transcriptional Activation of the CYP17 Gene in Porcine Theca Cells. Endocrinology, v.145, n.6, p. 2760-2766, 2004. 